
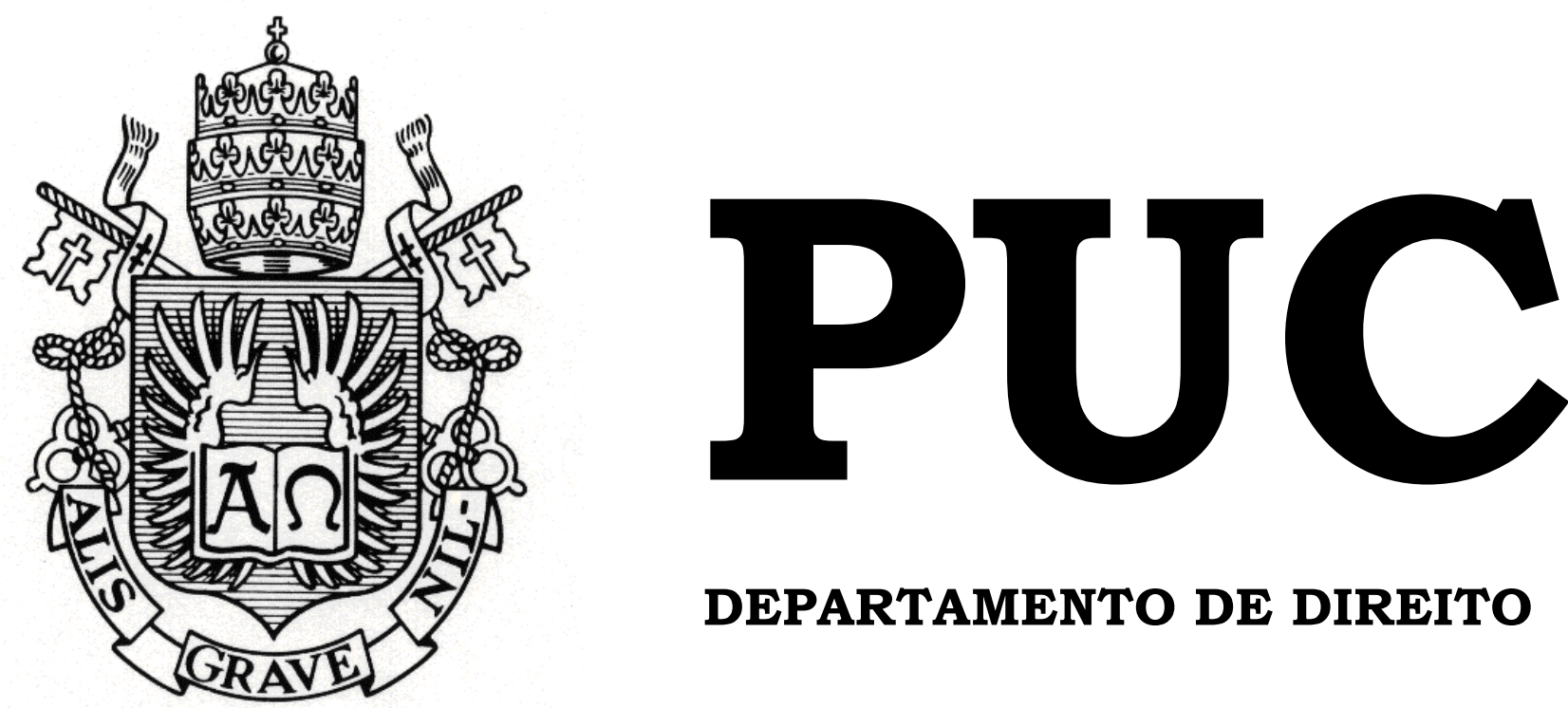

DEPARTAMENTO DE DIREITO

O NOVO CÓDIGO FLORESTAL (LEI 12.651/2012) À LUZ DO PRINCÍPIO DA VEDAÇÃO AO RETROCESSO SOCIOAMBIENTAL

por

LETÍCIA MARIA RÊGO TEIXEIRA LIMA

ORIENTADORA: PROFA. DRA. DANIELLE DE ANDRADE MOREIRA

2015.2

PONTIFÍCIA UNIVERSIDADE CATÓLICA DO RIO DE JANEIRO

RUA MARQUÊS DE SÃO VICENTE, 225 - CEP 22453-900

RIO DE JANEIRO - BRASIL 


\title{
O NOVO CÓDIGO FLORESTAL (LEI 12.651/2012) À LUZ DO PRINCÍPIO DA VEDAÇÃO AO RETROCESSO SOCIOAMBIENTAL
}

\author{
por
}

\section{LETÍCIA MARIA RÊGO TEIXEIRA LIMA}

Monografia apresentada ao Departamento de Direito da Pontificia Universidade Católica do Rio de Janeiro (PUC-Rio) para a obtenção do Título de Bacharel em Direito.

Orientadora: Profa. Dra. Danielle de Andrade Moreira. 
"Estamos diante de um momento crítico na história da Terra, numa época em que a humanidade deve escolher o seu futuro. À medida que o mundo torna-se cada vez mais interdependente e frágil, o futuro enfrenta, ao mesmo tempo, grandes perigos e grandes promessas. Para seguir adiante, devemos reconhecer que, no meio de uma magnífica diversidade de culturas e formas de vida, somos uma família humana e uma comunidade terrestre com um destino comum. Devemos somar forças para gerar uma sociedade sustentável global baseada no respeito pela natureza, nos direitos humanos universais, na justiça econômica e numa cultura da paz. Para chegar a este propósito, é imperativo que nós, os povos da Terra, declaremos nossa responsabilidade uns para com os outros, com a grande comunidade da vida, e com as futuras gerações."

Carta da Terra -2000 


\section{AGRADECIMENTOS}

Meus sinceros e profundos agradecimentos aos meus pais, Gilvan Alves Teixeira Lima e Jacinta Maria Rêgo Teixeira Lima, que me trouxeram ao mundo com toda a maturidade, responsabilidade e amor. Exemplos de honestidade, trabalho, humildade e de uma vida dedicada ao próximo. Vocês são o maior exemplo de que podemos fazer da nossa vida algo a ser lembrado.

Ao NIMA, representado pela Prof ${ }^{\mathrm{a}}$. Danielle de Andrade de Moreira, Prof ${ }^{\mathrm{a}}$. Virgínia Totti Guimarães e Prof. Fernando Walcacer, que me acolheram quando descobri que a proteção do meio ambiente é a batalha à qual resolvi me juntar. Não poderia estar mais bem acompanhada nesta trajetória e não poderia ter imaginado tamanha sorte quando frequentei pela primeira vez o grupo de estudos das quartas-feiras...

Ao Carlos Henrique Kuhlen, por ter estado presente de corpo e alma durante toda esta trajetória e me ajudado a entender que tudo tem seu tempo. Você estava lá quando eu descobri minha vocação e sempre foi meu maior incentivador.

À Prof ${ }^{a}$. Danielle, por quem nutro enorme admiração, um agradecimento especial. Seus exemplos de profissional apaixonada, de enorme coração e de mãe tão dedicada são uma grande inspiração.

À todos, minha eterna gratidão. 


\section{RESUMO}

O presente trabalho consiste em estudo sobre o princípio da vedação ao retrocesso socioambiental aplicado à edição de um novo Código Florestal, Lei federal no 12.651/2012.

Estruturado em uma análise do direito fundamental ao meio ambiente ecologicamente equilibrado, estabelecido pela Constituição Federal de 1988, bem como o desenvolvimento teórico relativo ao seu núcleo essencial, o ensaio perpassa a ideia de progresso relacionado aos direitos humanos, assim como pela teoria do mínimo existencial ecológico, para apresentar um panorama do princípio estudado, analisando-se seu histórico, conceito e aplicação pelo judiciário.

Por fim, realiza-se uma análise dos principais dispositivos e inovações trazidos pelo novo Código, à luz do princípio da vedação ao retrocesso socioambiental.

Palavras-chave: mínimo existencial ecológico; código florestal; lei 12.651/2012; princípio da vedação ao retrocesso socioambiental; área de preservação permanente; reserva legal; área rural consolidada. 


\section{SUMÁRIO}

LISTA DE ABREVIAÇÕES ................................................................ 6

INTRODUÇÃ

1. CONSTITUIÇÃO FEDERAL DE 1988 E A PROTEÇÃO DO

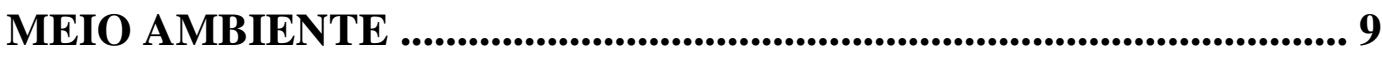

1.1. Breve histórico e deveres do Poder Público e da coletividade 9

1.2. Direito fundamental ao meio ambiente ecologicamente equilibrado

1.3. Núcleo essencial do direito fundamental ao meio ambiente ecologicamente equilibrado

2. PRINCÍPIO DA VEDAÇÃO AO RETROCESSO SOCIOAMBIENTAL 22

2.1. Ideia de progresso e gerações futuras ............................... 22

2.2. Mínimo existencial ecológico ......................................... 24

2.3. Origens e compreensão do princípio ................................ 27

2.4. Papel do Poder Judiciário e jurisprudência ....................... 31

3. NOVO CÓDIGO FLORESTAL ........................................... 36

3.1. Breve histórico ...................................................... 36

3.2. Interpretação da nova lei à luz do princípio da vedação ao retrocesso socioambiental .................................................... 41

3.2.1. Área rural consolidada ...................................... 41

3.2.2. Área de preservação permanente ............................. 44

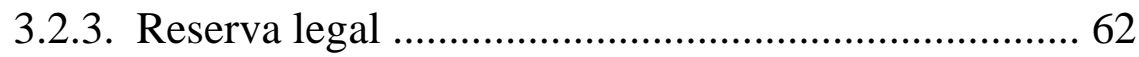

3.3 Jurisprudência relacionada ao novo Código Florestal .......... 72

CONCLUSÃO ............................................................................................... 75

REFERÊNCIAS BIBLIOGRÁFICAS .................................................. 79 


\section{LISTA DE ABREVIAÇÕES}

ADI Ação Direta de Inconstitucionalidade

APP Área de preservação permanente

CAR Cadastro ambiental rural

CRA Cota de reserva ambiental

RL Reserva legal

ETEP Espaço territorial especialmente protegido

STF Supremo Tribunal Federal

STJ Superior Tribunal de Justiça

UC Unidade de conservação 


\section{INTRODUÇÃO}

O presente trabalho tem como objetivo analisar alguns aspectos do atual Código Florestal ${ }^{1}$, Lei federal 12.651, de 25 de maio de 2012, sobre proteção da vegetação nativa, que revogou a Lei federal 4.771, de 15 de setembro de 1965, à luz do princípio da vedação ao retrocesso socioambiental.

As análises empreendidas neste trabalho levam em conta a relevância da proteção das florestas brasileiras para o equilíbrio ecológico e econômico do país, por tratar-se de lei que propõe o desenvolvimento sustentável mediante limitações à propriedade privada no que tange aos espaços territoriais especialmente protegidos.

Pretende-se demonstrar que a Lei 12.651/2012 padece de inconstitucionalidades em relação a dispositivos específicos da Constituição Federal e, principalmente, viola o princípio da vedação ao retrocesso. Busca-se avaliar se há compatibilidade da Lei aprovada com a Constituição, especificamente no que se refere ao núcleo essencial do direito fundamental ao meio ambiente ecologicamente equilibrado e a consequente observância do princípio da vedação ao retrocesso.

O trabalho aborda alguns dispositivos da Constituição, considerados como relevantes para a discussão relacionada à legislação florestal, como os deveres do Poder Público relacionados à proteção ambiental. Além disso, é demonstrado como a norma constitucional buscou capacitar o Poder Público e a sociedade para garantir tal proteção e, ao mesmo tempo, como

\footnotetext{
${ }^{1}$ A Lei federal 4.771/1965 instituía o Código Florestal anteriormente em vigor. Diferentemente, a Lei 12.651/2012 tem sido chamada de novo Código Florestal, muito embora não faça menção à esta denominação. Para os fins deste trabalho, considera-se a nova legislação sobre vegetação nativa como novo Código Florestal.
} 
pretendeu limitar esses mesmos atores com o intuito também protecionista do bem difuso.

Neste sentido, considerou-se necessário analisar o direito fundamental ao meio ambiente ecologicamente equilibrado, estabelecido na Constituição Federal, bem como o desenvolvimento teórico relativo ao seu núcleo essencial.

O princípio da vedação ao retrocesso é analisado com o objetivo de se buscar na doutrina mais especializada as justificativas de demonstrar o seu conteúdo e as características que o tornam tão necessário para a preservação do meio ambiente.

A partir do entendimento deste princípio, é empreendida uma análise dos dispositivos da Lei 12.651/2012 para se avaliar se houve retrocessos, ou seja, se é possível considerar que a Lei atual é menos protetiva do direito fundamental ao meio ambiente ecologicamente equilibrado do que a Lei revogada. 


\section{CONSTITUIÇÃO FEDERAL DE 1988 E A PROTEÇÃO DO MEIO AMBIENTE}

\subsection{Breve histórico e deveres do Poder Público e da coletividade}

A crise ambiental, assunto tão sensível nos dias atuais, começou a ser sentida e discutida após a Segunda Guerra Mundial. O grande marco inicial dessa transformação se deu na Conferência das Nações Unidas de 1972 sobre meio ambiente humano, que produziu um documento com diretrizes e princípios até hoje utilizados como referências em Direito Ambiental, a Declaração de Estocolmo.

A partir da década de 1970 houve um processo de ecologização das constituições em diversos países ${ }^{2}$. Em 1988, o Brasil promulgou a primeira Constituição verdadeiramente ecológica, elaborada com base num dever geral de solidariedade para com a humanidade, visando ao bem-estar coletivo $^{3}$. Teve, para isso, o cuidado de direcionar um capítulo específico para o meio ambiente (Título VIII, correspondente à Ordem Social, capítulo VI, intitulado "Do Meio Ambiente") e, consequentemente, toda uma nova interpretação do texto Constitucional, baseada numa visão protetiva e respeitadora do meio ambiente, associada aos objetivos constitucionais de bem-estar coletivo e de dignidade da pessoa humana.

O caput do artigo 225 da Constituição Federal positiva o direito fundamental ao meio ambiente ecologicamente equilibrado e prevê que:

Todos têm direito ao meio ambiente ecologicamente equilibrado, bem de uso comum do povo e essencial à sadia qualidade de vida, impondo-se ao Poder Público e à coletividade o dever de defendê-lo e preservá-lo para as presentes e futuras gerações.

\footnotetext{
2 BENJAMIN, Antonio Herman. Constitucionalização do Ambiente e Ecologização da Constituição Brasileira. In: CANOTILHO, José Joaquim Gomes; LEITE, José Rubens Morato (Org.). Direito Constitucional Ambiental Brasileiro. São Paulo: Saraiva, 2007. p. 59.

3 AYALA, Patryck de Araújo. Direito fundamental ao ambiente e a proibição de regresso nos níveis de proteção ambiental na Constituição brasileira. In: Senado Federal. Princípio da Proibição de Retrocesso Ambiental. Brasília: Senado Federal, 2012. Disponível em <http://www2.senado.gov.br/bdsf/handle/id/242559> Acesso em 20 de out. 2015. p. 212.
} 
A Constituição de 1988 representou um avanço - e ao mesmo tempo uma ruptura - no que se refere ao tratamento conferido ao meio ambiente em relação às anteriores, sendo a primeira a apresentar normas sobre o assunto e utilizar a expressão "meio ambiente"4. Além disso, inovou ao tutelar o meio ambiente como um bem jurídico per se, ou seja, que não está necessariamente atrelado a outro bem jurídico, tornando-o autônomo ${ }^{5} \mathrm{e}$ oponível erga omnes, consagrando, ainda, a "ética da solidariedade entre gerações" deveres aos seres humanos em favor de elementos bióticos e abióticos. ${ }^{7}$

A universalização dos direitos individuais, sociais e difusos permeia todo o texto constitucional. Desse modo, a proteção do meio ambiente não se encontra apenas no capítulo específico destinado ao tema, mas em diversos outros dispositivos, como os artigos $170^{8}$ e $186^{9}$, que determinam o atendimento da função social da propriedade na medida em que haja a preservação do meio ambiente, "sob pena de perversão de seus fins, de sua legitimidade e de seus atributos" ${ }^{\prime 10}$. Na visão de BENJAMIN, a constitucionalização do meio ambiente é sintetizada no artigo 225 e representa grandes avanços exemplificados por meio do trecho colacionado abaixo:

São múltiplas as vantagens da constitucionalização do meio ambiente, já vistas. Um exame da experiência estrangeira revela que a norma constitucional, comumente, estabelece uma obrigação genérica de não degradar, fonte do regime de explorabilidade limitada e condicionada dos recursos naturais; ecologiza o

\footnotetext{
${ }^{4}$ MACHADO, Paulo Affonso Leme. Direito Ambiental Brasileiro. 16ª ed.. São Paulo: Malheiros Editores LTDA, 2008. p. 122.

${ }^{5}$ MILARÉ, Édis. Direito do Ambiente: A gestão ambiental em foco: doutrina, jurisprudência, glossário. $7^{\mathrm{a}}$ ed.. São Paulo: Revista dos Tribunais, 2011. p. 176.

${ }^{6}$ MACHADO, Paulo Affonso Leme. Direito Ambiental Brasileiro. p. 155.

7 BENJAMIN, Antonio Herman. Constitucionalização do Ambiente e Ecologização da Constituição Brasileira. p. 111

${ }^{8}$ Art. 170, III, da Constituição Federal de 1988: “A ordem econômica, fundada na valorização do trabalho humano e na livre iniciativa, tem por fim assegurar a todos existência digna, conforme os ditames da justiça social, observados os seguintes princípios: III - função social da propriedade;"

${ }^{9}$ Art. 186, II, da Constituição Federal de 1988: "A função social é cumprida quando a propriedade rural atende, simultaneamente, segundo critérios e graus de exigência estabelecidos em lei, aos seguintes requisitos: II - utilização adequada dos recursos naturais disponíveis e preservação do meio ambiente;"

10 BENJAMIN, Antonio Herman. Constitucionalização do Ambiente e Ecologização da Constituição Brasileira. p. 120.
} 
direito de propriedade e sua função social; atribui perfil fundamental a direitos e obrigações ambientais; legitima a intervenção estatal em favor da natureza; reduz a discricionariedade administrativa no processo decisório ambiental; amplia a participação pública, em especial, nas esferas administrativas e judicial; agrega preeminência e proeminência à questão e aos conflitos ambientais; robustece a segurança normativa; substitui a ordem pública ambiental legalizada por outra de gênese constitucional; enseja o controle da constitucionalidade da lei sob bases ambientais; e, por fim, reforça a interpretação pró-ambiente das normas e políticas públicas. ${ }^{11}$

A Constituição andou bem ao incumbir ao Poder Público e à coletividade o papel de defesa e preservação do meio ambiente, tendo em vista a indisponibilidade do direito ora protegido e a consequente necessidade de defendê-lo da forma mais ampla possível. O Poder Público, entendido como o conjunto das três esferas de poder - Executivo, Legislativo e Judiciário - é o gestor dos chamados bens de uso comum do povo e não pode dispor de tais bens ou decidir de forma arbitrária em seus atos de gestão. ${ }^{12}$

O artigo 225, $\S 1^{\circ}$, determina, ao longo de sete incisos, deveres específicos do Poder Público para a proteção e preservação do meio ambiente, que, de acordo com MILARÉ, trata-se de um dever geral, positivo e verdadeira obrigação de fazer, ou seja, atuação vinculada, assim determinada pelo legislador constitucional ${ }^{13}$.

Os deveres do Poder Público previstos nos incisos do art. 225, $\S 1^{\text {o }}$, são a preservação e restauração dos processos ecológicos essenciais; a promoção do manejo ecológico das espécies e ecossistemas; a preservação da biodiversidade e controle de pesquisa e manipulação de material genético; definição de espaços territoriais especialmente protegidos; imposição de estudo prévio de impacto ambiental para instalação de obra ou atividade potencialmente causadora de significativa degradação do meio ambiente; controle da produção, comercialização e utilização de técnicas, métodos, e substâncias nocivas à vida, à qualidade de vida e ao meio

\footnotetext{
${ }^{11}$ BENJAMIN, Antonio Herman. Constitucionalização do Ambiente e Ecologização da Constituição Brasileira. p. 83.

${ }^{12}$ MACHADO, Paulo Affonso Leme. Direito Ambiental Brasileiro. p. 127.

${ }^{13}$ MILARÉ, Édis. Direito do Ambiente. p.190.
} 
ambiente; promoção da educação ambiental; e, por fim, a proteção à fauna e à flora ${ }^{14}$.

Da lista de incumbências do Poder Público na proteção do meio ambiente prevista no artigo $225, \S 1^{\circ}$, destacam-se, para a finalidade deste trabalho os seguintes incisos:

I - preservar e restaurar os processos ecológicos essenciais e prover o manejo ecológico das espécies e ecossistemas;

III - definir, em todas as unidades da Federação, espaços territoriais e seus componentes a serem especialmente protegidos, sendo a alteração e a supressão permitidas somente através de lei, vedada qualquer utilização que comprometa a integridade dos atributos que justifiquem sua proteção;

VII - proteger a fauna e a flora, vedadas, na forma da lei, as práticas que coloquem em risco sua função ecológica, provoquem a extinção de espécies ou submetam os animais a crueldade.

Percebe-se a intenção do legislador primário em garantir a proteção dos espaços territoriais especialmente protegidos (ETEP), assim como os processos e funções ecológicas por eles desempenhados. Tais espaços, regulamentados de forma não exaustiva pela Lei Federal 9.985, de 18 de julho de 2000, que trata das Unidades de Conservação (UC), são também definidos pelo Código Florestal, Lei federal 12.651/2012, quanto às áreas de preservação permanente (APP) e de reserva legal (RL). ${ }^{15}$

Portanto, é a partir da compreensão de que a Constituição definiu o meio ambiente equilibrado e sadio como direito fundamental da pessoa humana, um bem de natureza difusa, essencial à sadia qualidade de vida, bem como a partir das atribuições conferidas ao Poder Público para sua consecução e definição dos espaços territoriais especialmente protegidos, que deve ser interpretada toda a legislação infraconstitucional, inclusive a Lei federal 12.651/2012, conforme será analisado neste trabalho.

\footnotetext{
${ }^{14}$ MILARÉ, Édis. Direito do Ambiente. p. 190-211.

${ }^{15}$ BENJAMIN traça uma crítica à Lei Federal 9.985/2000 quanto à sua ementa que propõe definir os espaços territoriais especialmente protegidos, mas deixa de fora "as Áreas de Preservação Permanente, a Reserva Legal, a Reserva da Biosfera, as Áreas de Servidão Florestal, a Reserva Ecológica, os Monumentos Naturais Tombados e as Reservas Indígenas". BENJAMIN, Antônio Herman. Uma década de debate e negociação: a história da elaboração da Lei do SNUC. In: BENJAMIN, ANTÔNIO HERMAN (org.). Direito ambiental das áreas protegidas: o regime jurídico das unidades de conservação. Rio de Janeiro: Forense Universitária, 2001. p. 299
} 


\subsection{Direito Fundamental ao meio ambiente ecologicamente equilibrado}

Inicialmente, é necessário compreender que direitos e garantias fundamentais são as pretensões sociais de diversos momentos históricos que se relacionam ao valor da dignidade da pessoa humana. A gama desses direitos aumenta e engloba de forma cada vez mais adequada as necessidades da sociedade ${ }^{16}$. Formalmente, de acordo com a doutrina, direitos fundamentais são aqueles direitos que, "reconhecidos na Constituição ou em tratados internacionais, atribuem ao indivíduo ou a grupos de indivíduos uma garantia subjetiva ou pessoal." ${ }^{17}$. Por sua fundamentalidade, vinculam imediatamente as entidades públicas e privadas, ou seja, não dependem de lei para sua aplicação; além de serem dotados de irrenunciabilidade, inalienabilidade e imprescritibilidade ${ }^{18}$.

Mendes entende que alguns tipos de direitos fundamentais não seriam subjetivos, mas objetivos, o que possibilitaria uma preservação como valor em si. É essa dimensão objetiva que enseja o dever de proteção por parte do Poder Público contra entes públicos e particulares ${ }^{19}$. Nas palavras do autor:

Os direitos fundamentais, assim, transcendem a perspectiva da garantia de posições individuais, para alcançar a estrutura de normas que filtram os valores básicos da sociedade política, expandindo-os para todo o direito positivo. Formam, pois, a base do ordenamento jurídico de um Estado democrático. ${ }^{20}$

Necessário salientar, também, que direitos fundamentais podem ser divididos em formais ou materiais. Formais são aqueles que a Constituição define em um rol específico. Materiais são aqueles cuja existência é essencial para a implementação da dignidade da pessoa humana. Esta

\footnotetext{
${ }^{16}$ MENDES, Gilmar Ferreira; BRANCO, Paulo Gustavo Gonet. Curso de Direito Constitucional. $7^{a}$ ed.. São Paulo: Saraiva, 2012. p. 190.

17 BENJAMIN, Antonio Herman. Constitucionalização do Ambiente e Ecologização da Constituição Brasileira. p. 96-98.

18 BENJAMIN, Antonio Herman. Constitucionalização do Ambiente e Ecologização da Constituição Brasileira. p. 96-98.

${ }^{19}$ MENDES, Gilmar Ferreira; BRANCO, Paulo Gustavo Gonet. Curso de Direito Constitucional. p. 190.

${ }^{20}$ MENDES, Gilmar Ferreira; BRANCO, Paulo Gustavo Gonet. Curso de Direito Constitucional. p. 190.
} 
definição é importante para que direitos fundamentais que se encontram fora de um capítulo específico, também possam ser assim considerados ${ }^{21}$.

O Direito fundamental ao meio ambiente ecologicamente equilibrado começa a ser delineado na década de 1960, quando os direitos de terceira geração (dimensão) surgem na perspectiva dos direitos humanos, num caminhar para o chamado "direito dos povos". 22

MORAES, em ensaio sobre o princípio da solidariedade, narra brevemente o histórico e a conceituação do que sejam os direitos de terceira dimensão:

Afora a seguridade, o século XX assistiu ao desenvolvimento de novos direitos, os quais, na esteira dos direitos da liberdade e da igualdade, vieram trazer uma nova dimensão de fraternidade ou solidariedade, às constituições e aos ordenamentos ocidentais de um modo geral; daí se dizer que eles seriam direitos de "terceira geração". Entre esses direitos, que não tem por destinatário um indivíduo, um grupo ou um Estado específico, mas o próprio gênero humano, num momento expressivo de sua afirmação como valor supremo em termos de existencial idade concreta, foram incluídos os direitos ao desenvolvimento, à paz internacional, à comunicação e a um meio ambiente sadio e protegido. Neles, aflora uma concepção de solidariedade que é resultante de um anseio típico do século XX, quando pela primeira vez o homem se deparou com a hipótese da destruição do planeta e do esgotamento dos recursos naturais: o sentimento de estarmos, todos nós, "a bordo de um mesmo barco", fustigado por ameaças e tribulações globais que nos fazem, necessariamente, solidários uns aos outros. Estes sérios perigos, criados, na maior parte dos casos, pelo próprio homem e por uma (tecno)ciência que vem se perdendo nos excessos de um alegado progresso, geraram um novo dever, para o qual nossos antecessores não destinaram qualquer atenção: o respeito às gerações futuras. A preocupação - expressa, quanto ao meio-ambiente, no art. 225 da Constituição, que impõe ao Estado e à coletividade o dever de defendê-lo e preservá-lo para as presentes e futuras gerações - reflete a atual responsabilidade do homem, cuja capacidade de causar danos é bem conhecida, tanto no que se refere à extensão espacial, quanto à dimensão temporal. ${ }^{23}$

Trata-se de um direito que se diferencia dos de primeira dimensão (civis e políticos) e dos de segunda dimensão (sociais, culturais e econômicos). São direitos difusos ou transindividuais, cuja titularidade é

\footnotetext{
${ }^{21}$ PEREIRA, Jane Reis Gonçalves. Interpretação Constitucional e Direitos Fundamentais: uma contribuição ao estudo das restrições aos direitos fundamentais na perspectiva da teoria dos princípios. Rio de Janeiro: Renovar, 2006. p. 133.

${ }^{22}$ CANOTILHO, José Joaquim Gomes. Direito Constitucional e Teoria da Constituição. $7^{\mathrm{a}}$ ed. Coimbra: Almedina, 2003. p. 386

${ }^{23}$ MORAES, Maria Celina Bodin de. O Princípio da Solidariedade. In: PEIXINHO, Manoel Messias; Guerra, Isabella Franco; NASCIMENTO FILHO, Firly (Org.). Os Princípio das Constituição de 1988. Rio de Janeiro: Lumen Juris, 2006. p. 169-170.
} 
"indefinida ou indeterminável" 24 . É um direito dotado de primariedade, ou seja, não é subsidiário, e é, definitivamente, não programático. ${ }^{25}$ São aqueles direitos que facilmente afetam a coletividade, muitas vezes em escala global, por isso sua associação aos direitos da solidariedade e, por seu conteúdo material, são vinculados com a dignidade da pessoa humana $\left(\operatorname{artigo~} 1^{\circ} \text {, III da Constituição Federal }\right)^{26}$.

No âmbito da jurisprudência dos tribunais brasileiros, os direitos de terceira dimensão são amplamente reconhecidos e consolidados, como se verifica no Acórdão em mandado de segurança proferido pelo Supremo Tribunal Federal no ano de 1995:

O direito à integridade do meio ambiente - típico direito de terceira geração constitui prerrogativa jurídica de titularidade coletiva, refletindo, dentro do processo de afirmação dos direitos humanos, a expressão significativa de um poder atribuído, não ao indivíduo identificado em sua singularidade, mas num sentido verdadeiramente mais abrangente, à própria coletividade social. Enquanto os direitos de primeira geração (civis e políticos) - que compreendem as liberdades clássicas, negativas ou formais - realçam o princípio da liberdade e os direitos de segunda geração (direitos econômicos, sociais e culturais) - que se identificam com as liberdades positivas, reais ou concretas - acentuam o princípio da igualdade, os direitos de terceira geração, que materializam poderes de titularidade coletiva atribuídos genericamente a todas as formações sociais, consagram o princípio da solidariedade e constituem um momento importante no processo de desenvolvimento, expansão e reconhecimento dos direitos humanos, caracterizados, enquanto valores fundamentais indisponíveis, pela nota de uma essencial inexauribilidade. ${ }^{27}$.

Os direitos de terceira dimensão estão consolidados na jurisprudência brasileira e aparecem em outros julgados, a exemplo da Medida Cautelar em Ação Direta de Inconstitucionalidade $3540^{28}$ e da Ação

\footnotetext{
${ }^{24}$ FENSTERSEIFER, Tiago. Direitos fundamentais e proteção do ambiente: a dimensão ecológica da dignidade humana no marco jurídico constitucional do estado socioambiental de direito. Porto Alegre: Livraria do Advogado Editora, 2008. p. 149.

25 BENJAMIN, Antonio Herman. Constitucionalização do Ambiente e Ecologização da Constituição Brasileira. p. 98.

${ }^{26}$ FENSTERSEIFER, Tiago. Direitos fundamentais e proteção do ambiente. p. 168.

${ }^{27}$ STF, MS n. 22164-0, Rel. Ministro Celso de Mello, Brasília, 30 out. 1995.

28 "A preservação da integridade do meio ambiente: expressão constitucional de um direito fundamental que assiste à generalidade das pessoas. 'Todos tem direito ao meio ambiente ecologicamente equilibrado. Trata-se de um típico direito de terceira geração (ou de novíssima dimensão), que assiste a todo o gênero humano (RTJ 158/205-206). Incumbe, ao Estado e à própria coletividade, a especial obrigação de defender e preservar, em benefício das presentes e futuras gerações, esse direito de titularidade coletiva e de caráter transindividual (RTJ 164/158161). O adimplemento desse encargo, que é irrenunciável, representa a garantia de que não instaurarão, no seio da coletividade, os graves conflitos intergeracionais marcados pelo desrespeito
} 
Direta de Inconstitucionalidade $1.856^{29}$. A primeira discutia a constitucionalidade da redação do art. $4^{\circ}$ do antigo Código Florestal (Lei 4.771/1965) dada pela Medida Provisória 2.166-67, de 2001, e a segunda aborda a questão das brigas de galo, ambas decididas sob a égide dos direitos de terceira dimensão.

Assim, no contexto dos direitos de terceira dimensão, como demonstrado, que o Direito fundamental ao meio ambiente ecologicamente equilibrado surgiu e se consolidou na doutrina e na jurisprudência.

MILARÉ afirma que o meio ambiente ecologicamente equilibrado é um direito fundamental positivado pela Constituição de 1988 no artigo 225, caput $^{30}$ e BENJAMIN pontua que existe divergência sobre sua valoração dogmática, sendo considerado "direito fundamental na visão da Constituição de 1988 e direito da personalidade, na perspectiva do Direito Privado". 31

\begin{abstract}
A fundamentalidade do direito justifica-se, primeiro, em razão da estrutura normativa do tipo constitucional ("Todos têm direito ...); segundo, na medida em que o rol do art. $5^{\circ}$, sede principal de direitos e garantias fundamentais, por força do seu $\S 2^{\circ}$, não é exaustivo (direitos fundamentais há - e muitos - que não estão contidos no art. $5^{\circ}$ ); terceiro, porquanto, sendo uma extensão material (pois salvaguarda suas bases ecológicas vitais) do direito à vida, garantindo no art. $5^{\circ}$, caput, reflexamente, recebe deste as bençãos e aconchego, como adverte a boa lição de Nicolao Dino, segundo o qual "o direito ao meio ambiente caracteriza-se como um corolário do direito à vida. ${ }^{32}$
\end{abstract}

ao dever de solidariedade, que a todos se impõe, na proteção desse bem essencial de uso comum das pessoas em geral. Doutrina". STF, MC na ADI n. 3.540-1, Rel. Ministro Celso de Mello, Brasília, 01 set. 2005.

29 "Cabe assinalar, Senhor Presidente, que os direitos de terceira geração (ou de novíssima dimensão), que materializam poderes de titularidade coletiva atribuídos, genericamente, e de modo difuso, a todos os integrantes dos agrupamentos sociais, consagram o princípio da solidariedade e constituem, por isso mesmo, ao lado dos denominados direitos de quarta geração (como o direito ao desenvolvimento e o direito à paz), um momento importante no processo de expansão e reconhecimento dos direitos humanos, qualificados estes, enquanto valores fundamentais indisponíveis, como prerrogativas impregnadas de uma natureza essencialmente inexaurível, consoante proclama autorizado magistério doutrinário (CELSO LAFER, "Desafios: Ética e Política”, p. 239, 1995, Siciliano).” STF, ADI n. 1856, Rel. Ministro Celso de Mello, Brasília, 26 mai. 2011.

${ }^{30}$ MILARÉ, Édis. Direito do Ambiente: A gestão ambiental em foco: doutrina, jurisprudência, glossário. $7^{\mathrm{a}}$ ed.. São Paulo: Revista dos Tribunais, 2011. p. 1065.

31 BENJAMIN, Antonio Herman. Constitucionalização do Ambiente e Ecologização da Constituição Brasileira. In: CANOTILHO, José Joaquim Gomes; LEITE, José Rubens Morato (Org.). Direito Constitucional Ambiental Brasileiro. São Paulo: Saraiva, 2007. p. 98.

32 BENJAMIN, Antonio Herman. Constitucionalização do Ambiente e Ecologização da Constituição Brasileira. p. 102 - 103. 
É no contexto constitucional vigente de garantia dos direitos humanos de terceira dimensão, embasados em sólida doutrina e jurisprudência quanto aos direitos fundamentais que, frente às recentes modificações na legislação do Código Florestal, pela revogação da Lei federal 4.771/1965, se entendeu necessário abordar a questão do núcleo essencial do direito fundamental ao meio ambiente ecologicamente equilibrado.

\subsection{Núcleo Essencial do direito fundamental ao meio ambiente ecologicamente equilibrado}

Os direitos fundamentais protegidos pela Constituição possuem o que se chama de núcleo essencial, cujo conceito surgiu inicialmente na Constituição alemã de Bonn, de maio de 1949, e posteriormente em outras Constituições europeias como a portuguesa e a espanhola ${ }^{33}$.

Como assevera CHEQUER, a Constituição de Weimar, anterior à de Bonn, não previa a proteção do núcleo essencial dos direitos fundamentais e com o esvaziamento destes, sem, contudo, atentar-se contra a Constituição positivada, se deu a ascensão do nazismo na Alemanha ${ }^{34}$. Tal fenômeno foi possível porque a lei era obedecida sob o princípio da legalidade, sem o direcionamento dos direitos fundamentais. Estes não possuíam qualquer efetividade.

Após a Segunda Guerra Mundial, o constituinte alemão passou a estar vinculado ao conteúdo material dos direitos fundamentais ${ }^{35}$. E é através dessa vinculação necessária que a teoria do núcleo essencial se mostra útil, para que o conteúdo material essencial de cada direito

\footnotetext{
${ }^{33}$ FENSTERSEIFER, Tiago. Direitos fundamentais e proteção do ambiente. p. 222.

${ }^{34}$ CHEQUER, Cláudio. O princípio da proteção ao núcleo essencial do Direito Fundamental no Direito brasileiro (aplicação e delimitação). Disponível em $\langle$ http://www.cartaforense.com.br/conteudo/artigos/o-principio-da-protecao-ao-nucleo-essencialdo-direito-fundamental-no-direito-brasileiro-aplicacao-e-delimitacao/10163> Acesso em 20 out. 2015.

${ }^{35}$ PEREIRA, Jane Reis Gonçalves. Interpretação Constitucional e Direitos Fundamentais. p. 133.
} 
fundamental possa ser protegido, o que significa, nas palavras de FENSTERSEIFER:

[D]ar um contorno mínimo de eficácia normativa aos direitos fundamentais, bem como de colocar balizas ou limites normativos à atuação do legislador infraconstitucional. Trata-se da expressão denominada de "limites dos limites", ou seja, a garantia do núcleo essencial é um limite constitucional a possíveis limites e restrições postas pelo legislador infraconstitucional ao conteúdo dos direitos fundamentais. ${ }^{36}$

Percebe-se que a finalidade primordial é a proteção dos direitos fundamentais em face do Poder Legislativo. Comprovada a violação do núcleo essencial, a medida legislativa é inconstitucional e inválida.

A expressão "limites dos limites" (em alemão Schranken der Schranken) é amplamente utilizada pela doutrina europeia, como sendo os diversos limites estabelecidos pela constituição para leis limitativas de direitos. São limites impostos ao legislativo para legitimar sua atuação ${ }^{37}$. Para REIS, a finalidade de tais limites é garantir o conteúdo vinculante de um direito fundamental. Não obstaculizam a atuação legislativa, que é discricionária, mas não sendo limites autônomos, funcionam com caráter suplementar para "garantir a supremacia dos direitos fundamentais". São exemplos desses limites o núcleo essencial e o princípio da proporcionalidade $^{38}$.

Segundo CANOTILHO, o limite estabelecido pela teoria do núcleo essencial representa:

[L]iberdades e garantias que não podem, em caso algum, ser violadas. Mesmo nos casos em que o legislador está constitucionalmente autorizado a editar normas restritivas, ele permanece vinculado à salvaguarda do núcleo essencial dos direitos ou direitos restringidos. ${ }^{39}$

Ao contrário dos exemplos constitucionais europeus, como o português e o espanhol, a Constituição brasileira de 1988 não menciona de

\footnotetext{
${ }^{36}$ FENSTERSEIFER, Tiago. Direitos fundamentais e proteção do ambiente. p. 182.

${ }^{37}$ PEREIRA, Jane Reis Gonçalves. Interpretação Constitucional e Direitos Fundamentais. p. 133.

${ }^{38}$ PEREIRA, Jane Reis Gonçalves. Interpretação Constitucional e Direitos Fundamentais. p. 298, 299, 378.

${ }^{39}$ CANOTILHO, José Joaquim Gomes. Direito Constitucional e Teoria da Constituição. p. 458.
} 
forma explícita em seu texto uma proteção do núcleo essencial. Como demonstra REIS:

Primeiramente, cabe aduzir que, a entender-se a garantia do conteúdo essencial como um limite dos limites dos direitos fundamentais - isto é, como instrumento metódico de aplicação destes -, torna-se desimportante o fato de esta constar, ou não, de forma expressa no texto constitucional. É que, como se disse antes, as diversas ferramentas normativas que visam a balizar a liberdade do legislador quando se trata de restringir direitos fundamentais defluem da própria supremacia das normas constitucionais, podendo ser entendidas como regras metodológicas imanentes ao ordenamento jurídico. Nesse prisma, mesmo não estando explicitado no texto constitucional - como ocorre em relação à Carta Constitucional de 1988 -, à ideia de proteção do conteúdo essencial pode ser inferida logicamente do sistema de Constituição rígida. É possível entender a aludida garantia como uma consequência da noção de que os direitos fundamentais são "restrições a sua restrição e restringibilidade". O conteúdo da proteção do núcleo essencial dos direitos refere-se, assim, à necessidade de destacar que a atividade conformadora dos direitos fundamentais requer acentuada dose de cautela, tendo em vista a superlativa importância a eles atribuída na ordem jurídica. ${ }^{40}$

Da mesma forma, MENDES ${ }^{41}$ entende inequívoca a decorrência da garantia do núcleo essencial da Constituição de 1988, tendo em vista o modelo garantístico da mesma. Baseia-se, para tanto, no artigo $60, \S 4^{\circ}$ da Constituição Federal de 1988, que é clara ao estabelecer um "direitodever", referente ao direito fundamental ao meio ambiente, configurado no caput do artigo 225, ou seja, confere um direito ao meio ambiente ecologicamente equilibrado e simultaneamente impõe um dever geral de proteção desse direito pelo Estado, representado pelas imposições presentes nos incisos do $\S 1^{\circ}$, como mencionado. O Estado tem sua liberdade limitada ao adotar medidas referentes ao meio ambiente. É obrigado a atuar de forma protetiva, configurando-se como o próprio guardião desse direito $^{42}$.

A delimitação do núcleo essencial é matéria que divide a doutrina e gera muitas teorias que não cabem neste ensaio, mas que de acordo com REIS não seriam úteis ao direito brasileiro, tendo em vista que não existe na Constituição de 1988 a garantia expressa do núcleo essencial. A autora

\footnotetext{
${ }^{40}$ PEREIRA, Jane Reis Gonçalves. Interpretação Constitucional e Direitos Fundamentais. p. 376. ${ }^{41}$ MENDES, Gilmar Ferreira; BRANCO, Paulo Gustavo Gonet. Curso de Direito Constitucional. p. 245.
} 
considera ainda que todas as teorias, mesmo divergentes, buscam uma mesma finalidade que seria a proteção desse núcleo. E por isso considera desnecessário defini-lo autonomamente ${ }^{43}$.

SARLET entende a dificuldade de determinação do núcleo essencial, mas considera importante que jurisprudência e doutrina desenvolvam parâmetros para que seja possível sua aplicação. E, nessa medida, propõe:

Quando estivermos diante de um direito fundamental a prestações já concretizadas em nível infraconstitucional, parece-nos que o limite do conteúdo essencial deverá ser interpretado no sentido dos elementos essenciais do nível prestacional legislativamente definido, entendimento que nos conduz diretamente ao já anunciado problema da proibição de um retrocesso social (...). ${ }^{44}$.

BENJAMIN define que os instrumentos específicos para a garantia desse núcleo duro do direito fundamental ao meio ambiente dividem-se em duas classes, quais sejam, instrumentos diretos ou primários; e, indiretos ou procedimentais. Os primeiros seriam aqueles que atuam no "coração" do Direito Ambiental, ou seja, as áreas protegidas como áreas de preservação permanente e reserva legal que efetivamente protegem "biomas, ecossistemas e processos ecológicos essenciais". Os instrumentos ditos procedimentais geram resultados semelhantes àqueles ao "ampliarem o grau de disseminação de informação ambiental gerada e em circulação, e ao estabelecerem mecanismos de participação pública", sem, no entanto, atuar diretamente na proteção de um espaço especialmente protegido, mas aumentando o nível de participação pública relacionada à sua proteção. ${ }^{45}$

É a partir do fundamento de núcleo essencial direto ou indireto, associado ao dever de proteção por parte do Poder Público que BENJAMIN entende o surgimento do princípio jurídico da proibição de retrocesso ${ }^{46}$.

\footnotetext{
${ }^{42}$ FENSTERSEIFER, Tiago. Direitos fundamentais e proteção do ambiente. p. 223

${ }^{43}$ PEREIRA, Jane Reis Gonçalves. Interpretação Constitucional e Direitos Fundamentais. p. 378.

${ }^{44}$ SARLET, Ingo Wolfgang. A eficácia dos Direitos Fundamentais. Uma Teoria Geral dos Direitos Fundamentais na Perspectiva Constitucional. 11 $1^{\mathrm{a}}$ ed.. Porto Alegre: Livraria do Advogado, 2012. p. 413, 442.

${ }^{45}$ BENJAMIN, Antonio Herman. Princípio da Proibição de Retrocesso Ambiental. In: Senado Federal. Princípio da Proibição de Retrocesso Ambiental. Brasília: Senado Federal, 2012. Disponível em <http://www2.senado.gov.br/bdsf/handle/id/242559 > Acesso em 20 de out. 2015. p. 68 e 69 .

${ }^{46}$ BENJAMIN, Antonio Herman. Princípio da Proibição de Retrocesso Ambiental. p. 57 e 58
} 
Tendo em vista a construção doutrinária apresentada sobre o núcleo essencial do direito fundamental ao meio ambiente, cabe expor a interpretação dada pela Procuradora-Geral da União, CUREAU, em face da Lei 12.651/2012, no âmbito da Ação Direta de Inconstitucionalidade $4901^{47}$ :

[A]o fragilizar o regime de proteção das áreas de preservação permanente e das reservas legais, e em alguns casos, extingui-las, o legislador infraconstitucional violou integralmente os mandamentos constitucionais acima mencionados. Se, na lição de Konrad Hesse, "direitos fundamentais não podem existir sem deveres", é forçoso reconhecer que o legislador infraconstitucional atingiu o núcleo fundamental do direito ao meio ambiente ecologicamente equilibrado, negandolhe vigência e retirando sua força normativa. ${ }^{48}$

O núcleo essencial do direito fundamental ao meio ambiente abre o caminho e corrobora o desenvolvimento doutrinário do princípio da vedação ao retrocesso.

\footnotetext{
${ }^{47}$ Trata-se de Ação Direta de Inconstitucionalidade para discutir dispositivos da Lei 12.651/2012 que contrariam os artigos 186, I, e II e 225, todos os incisos, da Constituição Federal de 1988. STF, ADI n. 4901, Rel. Ministro Luiz Fux. Petição Inicial ajuizada pelo Ministério Público Federal, em 18 jan. 2013. Pendente de julgamento.

${ }^{48}$ STF, ADI n. 4901, Rel. Ministro Luiz Fux. Petição Inicial ajuizada pelo Ministério Público Federal, em 18 jan. 2013. Pendente de julgamento. p. 12.
} 


\section{PRINCÍPIO DA VEDAÇÃO AO RETROCESSO}

\subsection{Ideia de progresso e gerações futuras}

No âmbito da evolução dos Direitos Humanos, com foco na proteção da dignidade da pessoa humana e das gerações futuras, o meio ambiente ecologicamente equilibrado se afirmou como um direito fundamental, "política-valor"49 que busca o progresso constante da proteção do meio ambiente. Os Direitos Humanos, incluídos os de natureza ecológica, tem uma orientação progressiva, visando à constante melhoria da qualidade de vida da sociedade, orientação que se extrai das convenções internacionais sobre o assunto, à exemplo do Pacto Internacional sobre Direitos Econômicos, Sociais e Culturais, ratificado pelo Brasil em 1992 (Decreto 591) e da Declaração Universal dos Direitos Humanos que preveem:

Cada Estado Parte do presente Pacto compromete-se a adotar medidas, tanto por esforço próprio como pela assistência e cooperação internacionais, principalmente nos planos econômico e técnico, até o máximo de seus recursos disponíveis, que visem a assegurar, progressivamente, por todos os meios apropriados, o pleno exercício dos direitos reconhecidos no presente Pacto, incluindo, em particular, a adoção de medidas legislativas. ${ }^{50}$

Considerando que, na Carta, os povos das Nações Unidas proclamam, de novo, a sua fé nos direitos fundamentais do Homem, na dignidade e no valor da pessoa humana, na igualdade de direitos dos homens e das mulheres e se declaram resolvidos a favorecer o progresso social e a instaurar melhores condições de vida dentro de uma liberdade mais ampla. ${ }^{51}$

De forma semelhante, o Protocolo de San Salvador, adicional à Convenção Americana sobre Direitos Humanos em matéria de Direitos Econômicos, Sociais e Culturais, de 2007, prevê, em seu artigo 11, o direito a um meio ambiente sadio mediante a "proteção, preservação e

\footnotetext{
49 PRIEUR, Michel. O princípio da proibição de retrocesso ambiental. In: Senado Federal. Princípio da Proibição de Retrocesso Ambiental. Brasília: Senado Federal, 2012. Disponível em $\langle$ http://www2.senado.gov.br/bdsf/handle/id/242559> Acesso em 18 de out. 2015. p. 11.

${ }^{50}$ Art. $2^{\circ}$ do Pacto Internacional sobre Direitos Econômicos, Sociais e Culturais, de 16 de Dezembro de 1966.

${ }^{51}$ Preâmbulo da Declaração Universal dos Direitos Humanos, de 10 de dezembro de 1948.
} 
melhoramento" ${ }^{52}$ do mesmo, assim como a Declaração de Estocolmo, de 1972, prevê:

A proteção e o melhoramento do meio ambiente humano é uma questão fundamental que afeta o bem-estar dos povos e o desenvolvimento econômico do mundo inteiro, um desejo urgente dos povos de todo o mundo e um dever de todos os governos. ${ }^{53}$

Nessa perspectiva progressiva dos direitos humanos, o Brasil editou a Política Nacional do Meio Ambiente, em 1981, cujos objetivos são "a preservação, melhoria e recuperação da qualidade ambiental propícia à vida". 54

Assim, nas palavras de BENJAMIN, natural é o "caminhar somente para a frente" ${ }^{" 55}$ no que tange aos direitos humanos e a previsão dessa progressividade, como visto, inclui a dimensão ecológica, vinculando os Poderes Públicos à essa obrigação de melhora e vedando-lhes a capacidade de piorar o nível de proteção ambiental já alcançado, sempre visando a padrões mais elevados de proteção.

A progressão, portanto, é um objetivo comum dos direitos sociais, que impõe um dever de não regressão à Administração Pública, mas que não se confunde com o Princípio da Vedação ao Retrocesso. Este, não é um princípio que garanta a maximização da proteção ambiental, mas, para citar o adjetivo utilizado por ROTHENBURG, é um princípio mais modesto, que se contenta em garantir os direitos já alcançados, concretizados ou que razoavelmente ainda venham a se obter. Pretende impedir a perda de direitos e está relacionado com a segurança jurídica ${ }^{56}$.

O mínimo existencial ecológico é uma das garantias que o princípio da vedação ao retrocesso engloba. Portanto, antes de se falar

\footnotetext{
52 Art. 11 do Protocolo de San Salvador, de 17 de novembro de 1988.

${ }^{53}$ Art. $2^{\circ}$ da Declaração de Estocolmo, de 5 a 16 de junho de 1972.

${ }^{54}$ Art. $2^{\circ}$ da Lei 6.938, de 31 de Agosto de 1981.

${ }^{55}$ BENJAMIN, Antonio Herman. Princípio da Proibição de Retrocesso Ambiental. p. 57

${ }^{56}$ ROTHENBURG, Walter Claudius. Não retrocesso ambiental: direito fundamental e controle de constitucionalidade. In: Senado Federal. Princípio da Proibição de Retrocesso Ambiental. Brasília: Senado Federal, 2012. Disponível em

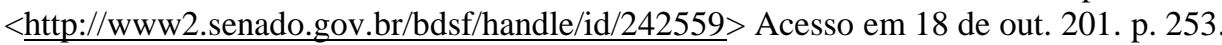


especificamente sobre os objetivos e características do princípio em comento, cabe entendermos o que é o mínimo existencial ecológico, expressão cunhada por SARLET.

\subsection{Mínimo existencial ecológico}

Diante da progressividade mencionada, e, de acordo com o desenvolvimento científico que eleva os padrões de proteção do meio ambiente com o passar do tempo, os limites mínimos protegidos pela não regressão são variáveis.

ROTHENBURG fala em "conteúdo mínimo" dos direitos fundamentais, mostrando uma relação íntima com o princípio do não retrocesso, na medida em que tais direitos não podem se esvaziar, mesmo que se alterem com o tempo. $\mathrm{O}$ autor afirma que:

O princípio do não retrocesso apanha as sucessivas reelaborações do conteúdo mínimo e impede que ele seja amesquinhado ou volte a padrões anteriores, quando menos desenvolvidos..$^{57}$

A vedação ao retrocesso busca garantir um mínimo existencial ecológico, que significa:

Um mínimo ecológico de existência tem a ver, portanto, com a proteção de uma zona existencial que deve ser mantida e reproduzida; mínimo que não se encontra sujeito a iniciativas revisoras próprias do exercício das prerrogativas democráticas conferidas à função legislativa. É neste ponto que a construção de uma noção de mínimo existencial (também para a dimensão ambiental) estabelece relações com um princípio de proibição de retrocesso para admitir também ali uma dimensão ecológica que deve ser protegida e garantida contra iniciativas retrocessivas que possam, em alguma medida, representar ameaça a padrões ecológicos elementares de existência. ${ }^{58}$

Esse mínimo a ser protegido é uma espécie de garantia do núcleo essencial do direito fundamental ao meio ambiente ecologicamente equilibrado. SOZZO entende que o progresso deve ser sustentável e eterno, com uma prospecção para as gerações futuras que devem receber os bens

\footnotetext{
${ }^{57}$ ROTHENBURG, Walter Claudius. Não retrocesso ambiental: direito fundamental e controle de constitucionalidade. In: Senado Federal. p. 257.

${ }^{58}$ AYALA, Patryck de Araújo. Direito fundamental ao ambiente e a proibição de regresso nos níveis de proteção ambiental na Constituição brasileira. p. 219.
} 
ambientais mais bem preservados do que a geração atual os recebeu ou, no mínimo, com o mesmo nível de qualidade. Raciocínio estritamente relacionado com a dignidade da pessoa humana e o direito à vida, pois não se restringe ao mínimo necessário para a sobrevivência, mas a um nível adequado para que esta se dê de forma saudável e digna. Por isso, define que o núcleo duro desse direito é o volume desses bens, patrimônio ambiental a ser transmitido, como se depreende do trecho abaixo:

Sem dúvidas, o problema central é determinar, identificar, o "núcleo duro" deste patrimônio. - Existem duas maneiras de definir este volume de bens que significa transferir às gerações futuras e que constitui o conteúdo do direito fundamental ao meio ambiente: a primeira, consiste em pensá-lo como "mínimo existencial" que não pode ser aniquilado; a segunda, é assegurar que o que se transfira seja o máximo de bens recebidos. A diferença entre os dois métodos não é só filosófica mas também estratégica uma vez que todos sabemos que é o que ocorre quando se renuncia a tudo, exceto ao essencial. Assim, o princípio de não regressividade - como majoritariamente tem sido entendido pela jurisprudência - para passar a ter um fundamento próprio, condição básica indispensável para alcançar uma fisionomia própria. ${ }^{59}$

A delimitação do que seja esse mínimo existencial, núcleo duro do direito fundamental ao meio ambiente ecologicamente equilibrado, não é simples e sofre críticas inclusive de autores consagrados pelo Direito Ambiental. PRIEUR ${ }^{60}$ entende que o mínimo não existe à priori e que deve variar de país para país, considerando as diferentes realidades regionais, além de ser necessária, sob seu ponto de vista, uma avaliação dos bens ambientais separadamente considerados para que se defina um nível adequado de proteção. Por isso, entende não haver um mínimo essencial em matéria ambiental abstratamente definido. Nesta seara, ele entende como

\footnotetext{
59 Tradução livre. No original: "Sin dudas el problema central es determinar, identificar, el "núcleo duro" de este patrimonio. - Existen dos maneras de definir este volumen de bienes que corresponde transferir a las generaciones futuras y que constituye el contenido del derecho fundamental al medio ambiente: la primera, consiste em pensarlo como "mínimo existencial" (168) que no puede ser aniquilado; la segunda es procurar que lo que se transfiera sea el máximo de bienes recibidos. La diferencia entre los dos métodos no es solo filosófica sino también estratégica puesto que todos sabemos qué es lo que ocurre cuando se renuncia todo, excepto a lo esencial. Así, el principio de no regresión deja de constituir uma derivación implícita de la idea de progresividad - como mayoritariamente lo ha entendido la jurisprudencia - para pasar a tener um fundamento propio, condición de base indispensable para alcanzar una fisionomía propia". SOZZO, Gonzalo. El principio de no retroceso en el campo de la teoría jurídica: El progreso como perdurabilidad para las generaciones futuras. In: PRIEUR, Michel; SOZZO, Gonzalo (Org.). La non régression en droit de l'environnement. Bruxelles: Bruylant, 2012. P. 65-89. p. 78

${ }^{60}$ PRIEUR, Michel. O princípio da proibição de retrocesso ambiental. p. 45-47.
} 
aplicável o princípio das responsabilidades comuns, porém diferenciadas, "o que levaria os limites a variarem segundo o território e os recursos econômicos considerados" $"$. O autor ressalta que o conteúdo mínimo deve ser, portanto, "a proteção máxima, consideradas as circunstâncias locais"62 e que, abaixo da qual não deve haver violação.

No Direito brasileiro observa-se três núcleos duros que representam o mínimo existencial ecológico, quais sejam, (i) "preservar e restaurar os processos ecológicos essenciais"; (ii) "preservar a diversidade e a integridade do patrimônio genético do País"; (iii) "proteger a fauna e a flora" e (iv) "impedir práticas que coloquem em risco sua função ecológica ou provoquem a extinção de espécies"; imperativos listados pelo artigo 225 da Constituição Federal no $\S 1^{\circ}$, I, II e VI, respectivamente. "Os dois primeiros, na forma de um facere, um "atuar" (= imperativo mínimo positivo); o terceiro, como um "evitar", um non facere (= imperativo mínimo negativo)". ${ }^{63}$

O que se revela necessário, para além de uma definição abalizada do que seja o mínimo ecológico, é saber que este é dinâmico e tende a ser cada vez maior na medida em que novas tecnologias permitam com mais eficiência a diminuição da poluição e dos processos produtivos danosos ao meio ambiente, uma melhor fiscalização dos mesmos, além de mecanismos de reparação mais eficazes, o que, gradativamente, consolida padrões de proteção ambiental mais altos. Por isso, ROTHENBURG enxerga que "o conteúdo mínimo não se revela um limite ao não retrocesso, mas, ao contrário, o não retrocesso revela-se um ampliador do conteúdo mínimo" ${ }^{\circ 4}$.

\section{Como conclui AYALA:}

Em síntese, é possível conceber a noção de mínimo ecológico de existência na condição de resultado que decorre da combinação do exercício da iniciativa estatal e dos particulares, objetivando assegurar a proteção de níveis de qualidade

\footnotetext{
${ }^{61}$ PRIEUR, Michel. O princípio da proibição de retrocesso ambiental. p. 46.

${ }^{62}$ PRIEUR, Michel. O princípio da proibição de retrocesso ambiental. p. 47.

${ }^{63}$ BENJAMIN, Antonio Herman. Princípio da Proibição de Retrocesso Ambiental. p. 66

${ }^{64}$ ROTHENBURG, Walter Claudius. Não retrocesso ambiental: direito fundamental e controle de constitucionalidade. In: Senado Federal. p. 257
} 
dos recursos naturais, que sejam indispensáveis para que se possa assegurar um conjunto de realidades existenciais dignas ao homem, compreendido este sob a forma de uma específica imagem de homem em um Estado de direito, que é social, democrático e ambiental. Compreende-se, sob a noção de um mínimo ecológico de existência que este homem, pessoa humana que deve ter asseguradas condições para o livre desenvolvimento de sua personalidade, somente pode fazê-lo se lhe estiverem acessíveis realidades existenciais capazes de proporcionar o exercício dessas liberdades. Garantias relacionadas a um conjunto mínimo de prestações de conteúdo social, econômico, cultural e, agora, ecológico, constituem o veículo para uma existência digna do homem como pessoa, destinatária da proteção estatal e não mais como objeto de sua iniciativa. A noção de mínimo ecológico de existência surge, portanto, conforme salientado, como uma consequência no plano existencial [no plano ecológico de existência] de um sistema de responsabilidades compartilhadas. ${ }^{65}$

Com base no exposto sobre o sentido de progresso dos direitos humanos e do mínimo existencial ecológico, parte-se para o entendimento do princípio da vedação ao retrocesso propriamente dito.

\subsection{Origens e compreensão do princípio}

Para garantir o nível de proteção alcançado pelos direitos sociais, econômicos, culturais e ecológicos, surgiu o chamado Princípio da Vedação ao Retrocesso Socioambiental, que nasce no bojo de uma perspectiva progressiva dos Direitos Humanos e visa à proteção do núcleo essencial dos direitos fundamentais e da dignidade da pessoa humana.

A diminuição da proteção do meio ambiente pela revogação ou alteração de leis ou políticas já existentes e em vigor, sem justificativa fundamentada, conduz ao fenômeno crescente de regressão, pelo qual passam as normas de diversos países. Por isso, o princípio da vedação ao retrocesso é reconhecido internacionalmente e possui diversas denominações. Na Bélgica é chamado de Standstill Principle, enquanto na França ganha o nome de efeito cliquet ou cliquet non-retour. Em inglês, também recebe a denominação de eternity clause e, em espanhol, prohibición de regressividad. ${ }^{66}$ No Brasil, também é chamado de princípio

\footnotetext{
${ }^{65}$ AYALA, Patryck de Araújo. Direito fundamental ao ambiente e a proibição de regresso nos níveis de proteção ambiental na Constituição brasileira. p. 228-229

${ }^{66}$ PRIEUR, Michel. O princípio da proibição de retrocesso ambiental. p. 14
} 
da proibição do retrocesso. Escolhemos a denominação, atribuída a

SARLET, de princípio da vedação ao retrocesso socioambiental.

Dois exemplos recentes de reconhecimento e aplicação constitucionais do princípio ora analisado estão na Constituição do Butão, de 2008, que estabelece uma cláusula de eternidade sobre $60 \%$ das florestas daquele país e na Constituição do Equador, também de 2008, que foi a primeira a, explicitamente, prever a não regressão em matéria ambiental. ${ }^{67}$

A doutrina estudada entende o princípio da vedação ao retrocesso como verdadeiro princípio constitucional implícito que tem amplo embasamento nos princípios do Direito Ambiental, tais como "prevenção, precaução, poluidor-pagador e participação do público", por isso também considerado como um princípio sistêmico, como se lê no trecho abaixo colacionado: 68

A proibição de retrocesso socioambiental, da mesma forma como ocorre com a proibição de retrocesso social, está, por sua vez, relacionada ao princípio da segurança jurídica e dos seus respectivos desdobramentos (princípio da proteção da confiança e as garantias constitucionais do direito adquirido, do ato jurídico perfeito e da coisa julgada), bem como guarda conexão com os limites materiais à reforma constitucional, considerando que tais institutos também objetivam a tutela de direitos e bens de matriz constitucional em face de atos e/ou medidas de caráter retroativo ou que venham, de algum modo, afetar situações e posições jurídicas. A estabilidade institucional (incluindo a estabilidade jurídica) é fundamental para o exercício dos direitos fundamentais do cidadão, na medida em que a dignidade humana não restará suficientemente respeitada e protegida onde as pessoas estejam expostas a tal nível de instabilidade jurídica que não estejam mais em condições de, com um mínimo de segurança e tranquilidade, confiar nas instituições sociais e estatais (incluindo o Direito) e numa certa estabilidade das suas próprias posições jurídicas. A proibição de retrocesso, nesse cenário, diz respeito mais especificamente a uma garantia de proteção dos direitos fundamentais (e da própria dignidade da pessoa humana) contra a atuação do legislador, tanto no âmbito constitucional quanto - e de modo especial infraconstitucional (quando estão em causa medidas legislativas que impliquem supressão ou restrição no plano das garantias e dos níveis de tutela dos direitos já existentes), mas também proteção em face da atuação da administração pública ${ }^{69}$

\footnotetext{
${ }^{67}$ PRIEUR, Michel. O princípio da proibição de retrocesso ambiental. p. 32-34

${ }^{68}$ BENJAMIN, Antonio Herman. Princípio da Proibição de Retrocesso Ambiental. p. 62-64

${ }^{69}$ SARLET, Ingo Wolfgang; FENSTERSEIFER, Tiago. Notas sobre a proibição de retrocesso em matéria (sócio)ambiental. In: Senado Federal. Princípio da Proibição de Retrocesso Ambiental. Brasília: Senado $\quad$ Federal, 2012. Disponível em <http://www2.senado.gov.br/bdsf/handle/id/242559> Acesso em 20 de out. 2015. p. 141-144.
} 
Revela-se, portanto, um princípio combativo face ao legislador e à Administração Pública, direcionado a garantir um mínimo de segurança jurídica e de proteção do direito objetivamente consolidado, impedindo que uma lei ou política nova diminua o grau de efetividade já alcançado e submetendo-a a uma avaliação empírica e comparativa com a anterior ${ }^{70}$. Por isso, entende-se que o legislador está vinculado ao nível de proteção legal alcançado pela legislação infraconstitucional, sendo vedada qualquer medida retrocessiva que afete o núcleo essencial do direito fundamental em questão, sendo este o parâmetro de sua vinculação. O Estado pode, inclusive, ser responsabilizado pelas "omissões legislativas que não assegurem o cumprimento dessa imposição genérica." O que não significa que o legislador encontra um impedimento absoluto à sua atuação. A limitação deste encontra-se, como mencionado, no "núcleo essencial” já alcançado pelo Direito.

Cabe ao Poder Público atuar no âmbito da dupla dimensão do princípio da proporcionalidade, "entre a proibição de excesso de intervenção, por um lado, e a proibição de insuficiência de proteção, por outro". ${ }^{71}$ Como explica SARLET:

Assim, ganha destaque a já retratada noção de que no campo da edição de atos legislativos e administrativos que afetam o âmbito de proteção dos direitos socioambientais, é preciso ter sempre presente que tanto o legislador quanto o administrador encontram-se vinculados as proibições de excesso e de insuficiência de proteção, portanto, deverão observar as exigências internas da proporcionalidade, quais sejam, da adequação, da necessidade e da proporcionalidade em sentido estrito, bem como da razoabilidade, que aqui não serão objeto de aprofundamento, mas que são - juntamente com a segurança jurídica (em especial a proteção da confiança e a tutela dos direitos adquiridos) reconhecidos por expressiva doutrina como indispensáveis também ao controle de medidas restritivas em matéria de direitos socioambientais. ${ }^{72}$

Sobre o princípio da vedação ao retrocesso, ROTHENBURG aponta para a existência de duas dimensões, uma (i) dimensão positiva, que

\footnotetext{
${ }^{70}$ AYALA, Patryck de Araújo. Direito fundamental ao ambiente e a proibição de regresso nos níveis de proteção ambiental na Constituição brasileira. p. 236.

${ }^{71}$ SARLET, Ingo Wolfgang; FENSTERSEIFER, Tiago. Notas sobre a proibição de retrocesso em matéria (sócio)ambiental. p. 135-138.

${ }^{72}$ SARLET, Ingo Wolfgang; FENSTERSEIFER, Tiago. Notas sobre a proibição de retrocesso em matéria (sócio)ambiental. p. 167.
} 
representa a promoção dos direitos fundamentais através do princípio e uma (ii) dimensão negativa, que é a proteção ou defesa do núcleo essencial do direito fundamental em questão, que, segundo o autor, seria uma dimensão mais fácil de ser compreendida.

De acordo com BENJAMIN, o retrocesso pode ser substantivo, procedimental, legislativo ou de implementação ${ }^{73}$ e pode afetar instrumentos do Direito Ambiental principais ou acessórios. Considera-se como principais aqueles que atuam no cerne da questão, salvaguardando "biomas, ecossistemas e processos ecológicos essenciais, entre eles cabendo citar as áreas protegidas, a reserva legal, as APP, a declaração de árvore imune a corte" ${ }^{74}$ Como observa o autor, "o que se espera, em boa parte dos casos, é um non facere, representado, na proteção jurídica do habitat, sobretudo da flora, como um "não desmatar" ou "não destruir"75.

Ademais, cabe chamar a atenção para a necessidade de, no âmbito do Direito Ambiental, afastar-se o princípio da mutabilidade do Direito em sopesamento com o princípio da vedação ao retrocesso, pois, como salienta PRIEUR, os direitos humanos constituem uma exceção ao princípio da mutabilidade do Direito, de acordo com o qual, uma geração não pode submeter outra geração às suas leis. ${ }^{76}$ "A regra lex posterior derogat priori encontra-se, assim, afastada em benefício da não regressão, que se exprime através da ideia da busca da proteção mais estrita para o ambiente" ${ }^{77}$. Inobstante as críticas de suposto imobilismo que o princípio traria ao direito, o autor ressalta a particularidade do Direito Ambiental, que defende o direito à vida das presentes e futuras gerações, diferenciando-se dos demais ramos. ${ }^{78}$

\footnotetext{
${ }^{73}$ BENJAMIN, Antonio Herman. Princípio da Proibição de Retrocesso Ambiental. p. 67.

${ }^{74}$ BENJAMIN, Antonio Herman. Princípio da Proibição de Retrocesso Ambiental. p. 69.

${ }^{75}$ BENJAMIN, Antonio Herman. Princípio da Proibição de Retrocesso Ambiental. p. 60.

${ }^{76}$ PRIEUR, Michel. O princípio da proibição de retrocesso ambiental. p. 19.

${ }^{77}$ PRIEUR, Michel. O princípio da proibição de retrocesso ambiental. p. 28.

${ }^{78}$ PRIEUR, Michel. O princípio da proibição de retrocesso ambiental. p. 48.
} 
Portanto, é possível perceber que o princípio da vedação ao retrocesso é indispensável pois protege o meio ambiente e consequentemente a sadia qualidade de vida do ser humano e das gerações vindouras. Por isso, considera-se inconstitucional a violação ao núcleo essencial do direito fundamental ao meio ambiente ecologicamente equilibrado e passa-se a analisar o papel do judiciário neste campo e a jurisprudência quanto ao assunto.

\subsection{Papel do Poder Judiciário e jurisprudência}

Admitido no âmbito dos direitos sociais pela jurisprudência, o princípio da vedação ao retrocesso socioambiental ainda precisa ser consagrado em seu viés judicial, muito embora a doutrina seja pacífica quanto ao alcance do mesmo.

Omissões legislativas e tentativas de enfraquecimento ou revogação de normas que projetam o direito fundamental ao meio ambiente equilibrado provocam a atuação do Poder Judiciário, que terá, de acordo com PRIEUR, "o trabalho de mensurar até onde se poderá regredir sem que isso implique condenar o edifício"79.

Medidas que violem o núcleo essencial de um determinado direito fundamental, diminuindo sua efetividade, são passíveis de controle de constitucionalidade. BENJAMIN, sobre essa questão, propõe questionamentos que o juiz deve propor a si mesmo para verificar se há retrocessos no caso concreto. Lê-se abaixo:

O princípio da proibição de retrocesso não institui camisa de força ao legislador e ao implementador, mas impõe-lhes limites não discricionários à sua atuação. Especificamente, no caso da proteção de biomas, ecossistemas e espécies, será a seguinte a pergunta que o juiz sempre se fará: as alterações legislativas ou políticas de implementação mantêm ou ampliam as garantias do meio ambiente? Asseguram a proteção dos "processos ecológicos essenciais"? Escudam, eficaz e eficientemente, as espécies ameaçadas de extinção? Ampliam ou reduzem os riscos ambientais a habitats vulneráveis? Estabelecem, naquilo que se revisa ou modifica, alternativas técnicas capazes de alcançar os mesmos ou similares

\footnotetext{
${ }^{79}$ PRIEUR, Michel. O princípio da proibição de retrocesso ambiental. p. 48.
} 
resultados da norma ou política de implementação revogada? Reduzem ou mantêm o grau de dificuldade de execução, bem como de cobrança administrativa e judicial (os chamados custos de transação da execução da lei) ? ${ }^{80}$

O princípio da vedação ao retrocesso, portanto, deve ser consagrado e aplicado pela doutrina e jurisprudência, além de invocado em face de medidas retrocessivas que firam o núcleo essencial dos direitos fundamentais consolidados e, neste caso, quando desvirtuem o princípio fundamental ao meio ambiente ecologicamente equilibrado. Nessa medida, ROTHENBURG ${ }^{81}$ afasta a alegação de que a intervenção do Judiciário seria contramajoritária, tendo em vista que muitas vezes as iniciativas legislativas são viciadas por grupos de interesses restritos que ferem direitos fundamentais, muito embora aparentem ter mais legitimidade do que aparentemente teria o Poder Judiciário. Este, representado pela Corte constitucional, é majoritário e legítimo quando atende aos interesses do constituinte originário na proteção do direito fundamental ao meio ambiente ecologicamente equilibrado previsto no artigo 225 da Constituição Federal.

Assim, entende-se legítima a atuação do Judiciário para sanar questões relativas a medidas que diminuam padrões de proteção ambiental e tenham a capacidade de violar o núcleo essencial do direito fundamental em questão.

O Ministério Público tem o papel fundamental de questionar medidas retrocessivas e despertar o controle de constitucionalidade, como ocorreu no caso do novo Código Florestal, Lei 12.651/2012, que será estudado neste trabalho, no qual a Subprocuradora-Geral da República, CUREAU, impugnou, em três Ações Diretas de Inconstitucionalidade ${ }^{82}$, diversos dispositivos da lei mencionada, baseando-se, entre outros fundamentos, no princípio da vedação ao retrocesso socioambiental.

\footnotetext{
${ }^{80}$ BENJAMIN, Antonio Herman. Princípio da Proibição de Retrocesso Ambiental. p. 69-70.

${ }^{81}$ ROTHENBURG, Walter Claudius. Não retrocesso ambiental: direito fundamental e controle de constitucionalidade. p. 262-263.

${ }^{82}$ STF, ADI n. 4901, Rel. Ministro Luiz Fux. Petição Inicial ajuizada pelo Ministério Público Federal, em 18 jan. 2013. Pendente de julgamento; STF, ADI n. 4902, Rel. Ministro Luiz Fux. Petição Inicial ajuizada pelo Ministério Público Federal, em 18 jan. 2013. Pendente de julgamento;
} 
Foi realizada pesquisa jurisprudencial ${ }^{83}$, no âmbito do Supremo Tribunal Federal e do Superior Tribunal de Justiça em busca de acórdãos que fizessem menção ao princípio da vedação ao retrocesso em matéria ambiental, no entanto apenas um resultado foi encontrado em matéria ambiental. Os demais acórdãos são relacionados ao princípio da vedação ao retrocesso social que, como dito anteriormente, estão mais consolidados pela jurisprudência e variam entre direito à saúde; direito do trabalho; seguridade social; direito eleitoral; direito à assistência judiciária gratuita; direito à educação; direito à segurança pública; direito tributário, reforma agrária e direito sucessório. A pesquisa incluiu os seguintes elementos de busca em ambos os tribunais: "vedação proibição retrocesso"; "vedação retrocesso"; "proibição retrocesso"; "princípio retrocesso"; "vedação retrocesso ambiental"; "vedação retrocesso ambiente"; "proibição retrocesso ambiental"; "proibição retrocesso ambiente"; "princípio retrocesso ambiental" e "princípio retrocesso ambiente". Os resultados numéricos estão abaixo organizados em uma tabela de acordo com o tribunal correspondente:

\begin{tabular}{|l|l|l|}
\hline & STF & STJ \\
\hline "vedação proibição retrocesso" & 14 & 13 \\
\hline “vedação retrocesso" & 19 & 13 \\
\hline "proibição retrocesso" & 25 & 13 \\
\hline "princípio retrocesso" & 33 & 32 \\
\hline "vedação retrocesso ambiental" & 0 & 1 \\
\hline "vedação retrocesso ambiente" & 2 & 1 \\
\hline "proibição retrocesso ambiental" & 0 & 1 \\
\hline "proibição retrocesso ambiente" & 2 & 1 \\
\hline "princípio retrocesso ambiental" & 0 & 1 \\
\hline "princípio retrocesso ambiente" & 2 & 1 \\
\hline
\end{tabular}

STF, ADI n. 4903, Rel. Ministro Luiz Fux. Petição Inicial ajuizada pelo Ministério Público Federal, em 18 jan. 2013. Pendente de julgamento.

${ }^{83}$ Pesquisa realizada em 27 de out. 2015. 
O acórdão encontrado sobre princípio da vedação ao retrocesso em matéria ambiental é do STJ e corresponde ao Recurso Especial 302.906, julgado em 26 de outubro de 2010, sob relatoria do Ministro Herman Benjamin.

Trata-se do notório caso do loteamento City Lapa, no Município de São Paulo, no qual foram discutidas as restrições urbanístico-ambientais convencionais estabelecidas pelo loteador, que são aprovadas pela Prefeitura e fazem parte da licença urbanística, em face da construção de um prédio de nove andares num bairro residencial composto apenas por casas. O Recurso Especial fora interposto pela empresa construtora do referido prédio, em face do acórdão do tribunal de origem que determinava a demolição do mesmo. Foi negado provimento ao recurso por maioria, de acordo com o voto do Ministro relator Herman Benjamin, que entre outros fundamentos, baseou-se no princípio da vedação ao retrocesso:

Em linha de princípio - princípio inescapável -, o Estado só está autorizado a flexibilizar restrições urbanístico-ambientais convencionais na presença de inequívoco interesse público, incapaz de ser atendido por outra via ou mecanismo menos gravoso à coletividade de vizinhos, jamais para satisfazer interesses políticos de momento, contingências eleitorais, arroubos populistas, objetivos imediatistas, ou para se curvar a demandas da febre insaciável da especulação imobiliária. Vale dizer, o legislador pode, sim, abrandar as exigências urbanístico-ambientais convencionais. No entanto, ao contrário do amplo poder de intervenção que lhe confere a ordem constitucional e legal vigente para aumentar seu rigor, ao reduzi-lo só poderá fazê-lo em circunstâncias excepcionais e de maneira cabalmente motivada. Essa regra geral, aplicável ao Direito Urbanístico (em sintonia com igual fenômeno no Direito Ambiental), é decorrência da crescente escassez de espaços verdes e dilapidação da qualidade de vida nas cidades e submete-se ao princípio da não-regressão (ou, por outra terminologia, princípio da proibição de retrocesso ), garantia de que os avanços urbanístico-ambientais conquistados no passado não serão destruídos ou negados pela geração atual. Diante dessas premissas, todas sindicáveis judicialmente, ao Poder Legislativo - e nunca à Administração de maneira ad hoc, por meio de atos administrativos individualizados e casuísticos - cumpre compatibilizar o interesse público, geral por excelência, e os interesses privados, individuais por excelência, mesmo que para tanto seja obrigado a afastar as restrições convencionais, sobretudo quando, por alteração profunda e irreversível das circunstâncias, o que sobeja aos vizinhos não vai além de um "interesse nominal", sem qualquer "benefício substantivo" a seu favor ou algo de valor que lhe sobre para oferecer à coletividade (Donald G. Hagman and Julian Conrad Juergensmeyer, Urban Planning and Land Development Control Law, St. Paul, West Publishing Company, 1986, p. 581). Dito de outra forma, as restrições urbanístico-ambientais convencionais não estão imunes à intervenção do Estado, o que é o mesmo que atribuir ao Poder Público a titularidade, no caso de 
flexibilização, de um poder de modificabilidade estritamente condicionada e sindicável judicialmente, assim denominada por se sujeitar a rigorosos pressupostos específicos. ${ }^{84}$

Por todo o exposto, percebe-se que o princípio da vedação ao retrocesso socioambiental está consolidado pela doutrina e que ainda necessita de maior atenção dos tribunais superiores, tendo em vista o $\begin{array}{lllll}\text { escasso } & \text { resultado } & \text { encontrado }\end{array}$

${ }^{84}$ STJ, Resp n. 302.906/SP, Rel. Ministro Herman Benjamin, Brasília, 26 ago. 2010. 


\section{NOVO CÓDIGO FLORESTAL (LEI 12.651/2012)}

\subsection{Breve histórico}

Historicamente, no Brasil colonial já havia regras sobre extração de madeira, proteção de determinados tipos de árvores, licença prévia para extração de produtos florestais, etc. Desde a Carta Régia, de 1442, passando pelo Regimento do pau brasil, de 1605, até o primeiro Código Florestal brasileiro, instituído pelo Decreto 23.793/1934, houve diversas leis e ordenações que disciplinaram a matéria florestal, sempre numa perspectiva econômica da mesma.

O Código Florestal de 1934 surgiu no bojo de diversas normas ambientais federais influenciados pela Constituição vigente, também de 1934, que determinava a proteção das "belezas naturais". Nesse contexto, surgiu o Código de Mineração, o Código de Caça e Pesca, o Código de Águas e o próprio Código Florestal, cujo objetivo “era essencialmente produtivista, classificando a maior parte das florestas do país como "de rendimento" e colocando, como modelo de floresta, a "silvicultura ordenada e produtiva". ${ }^{85}$ Já naquele momento, se observa a preocupação com a preservação de áreas não desmatadas no interior de grandes propriedades privadas, prevendo a obrigação de manutenção de $25 \%$ da propriedade preservados, além da preocupação com as florestas "protetoras" e "remanescentes", futuras reservas legais (RL) e áreas de preservação permanente (APP).

O segundo Código Florestal brasileiro, Lei federal 4.771/1965, que esteve em vigor até o ano de 2012, preocupava-se com "a manutenção do ciclo hidrológico, com a degradação do solo, em consequência do modo de

\footnotetext{
${ }^{85}$ LIMA, André; BENSUSAN, Nurit; RUSS, Lian. Código Florestal: por um debate pautado em ciência. Brasília: Instituto de Pesquisa Ambiental da Amazônia (IPAM), 2014. p. 9. Disponível em $<$ http://www.ipam.org.br/biblioteca/livro/Estudo-do-Ipam-mergulha-na-producao-cientificaexistente-para-entender-importancia-das-florestas/761> Acesso em 27 out. 2015.
} 
produção, com as enchentes anormais, com os processos de desertificação e com a futura escassez dos recursos naturais" ${ }^{\$ 6}$. Por isso, tratava-se de uma lei com objetivos ambientais instrumentais, como pontua RODRIGUES ${ }^{87}$. Criou instrumentos de proteção das áreas sensíveis, as áreas de preservação permanente (APP), e de preservação dos biomas existentes no território nacional, a reserva legal (RL), trazendo, assim, um avanço aos parâmetros de proteção ambiental, em sentido amplo, como aponta BENJAMIN:

Há precedentes do STJ que deixam muito claro que o Código Florestal anterior (e o atual, na mesma linha e, agora, de forma até mais explícita) salvaguarda não apenas as formações florestais stricto sensu, como, igualmente, com idêntico rigor, as demais formas de vegetação nativa. Vale dizer, o espaço ecológico em que recai o Código vai da densa floresta amazônica à vegetação rasteira das bordas do mar, da mata rala e retorcida do Cerrado e da Caatinga aos campos de altitude - p. ex., os encontrados no Rio Grande do Sul, cujas gramíneas, às vezes endêmicas e raras, não passam, ao olhar do leigo, de "grama" vulgar que, como tal, é perfeitamente fungível, ou seja, substituível por espécies exóticas e invasoras, como o capim braquiária (Brachiaria decumbens). ${ }^{88}$

No caminhar histórico-jurídico de proteção das florestas e do meio ambiente de modo geral, houve a edição da Lei da Política Nacional do Meio Ambiente, Lei federal 6.938/1981; da Lei de Crimes e Infrações Contra o Meio Ambiente, Lei federal 9.605/1998; e sua posterior regulamentação por meio do Decreto federal 6.514/2008 89 ; da Resolução 3.545 do Banco Central, que previa a necessidade de regularidade ambiental das propriedades rurais para a concessão de crédito agrícola; além de alterações no próprio Código Florestal, a exemplo da Medida Provisória 1.511/1996, que, devido à pressão internacional diante do aumento do desmatamento na Amazônia, introduziu medidas ainda mais protetivas na Lei federal 4.771/1965, como, por exemplo, o impedimento de

\footnotetext{
${ }^{86}$ LIMA, André; BENSUSAN, Nurit; RUSS, Lian. Código Florestal: por um debate pautado em ciência. Brasília. p. 9

${ }^{87}$ RODRIGUES, Marcelo Abelha. Áreas consolidadas no Código Florestal (Lei 12.651/2012): uma vergonha sem precedentes no Direito Ambiental. In: LECEY, Eladio Luiz da Silva; CAPELLI, Silvia (Org.) Revista de Direito Ambiental. São Paulo: Revista dos Tribunais, 2013. p. 346

${ }^{88}$ BENJAMIN, Herman. Hermenêutica do Código Florestal. p. 167

${ }^{89}$ Dispõe sobre as infrações e sanções administrativas ao meio ambiente, estabelece o processo administrativo federal para apuração destas infrações, e dá outras providências. Revogou o Decreto 3.179, de 21 de setembro de 1999.
} 
novas conversões de floresta em áreas de pecuária ou agricultura, entre muitos outros exemplos.

Tais medidas implicaram uma maior fiscalização e consequente aplicação do Código Florestal, que até então era extremamente desrespeitado. Neste ínterim, teve início uma movimentação pela revogação do Código Florestal então vigente, Lei federal 4.771/1965, capitaneada pela bancada ruralista do Congresso Nacional, que via nas garantias de proteção do meio ambiente estabelecidas pelo Código Florestal de 1965 um verdadeiro desrespeito ao direito de propriedade, entendendo-o como ilimitado e esvaziado quanto de funções sociais.

Fruto de um polêmico e atribulado processo legislativo, o Projeto de Lei 1.876/1999, de autoria do deputado Aldo Rebelo, foi aprovado pela Câmara dos Deputados em maio de 2011 e, em maio de 2012, passou pelo crivo da Presidente Dilma Roussef que, a despeito do movimento "Veta Dilma" que tomou conta das redes sociais e das discussões do povo brasileiro naquele momento, foi sancionado pelo Executivo com 12 vetos que em nada impediram o retrocesso da legislação, mas serviram, por consequência, para calar a população que, na maioria das vezes desconhecedora dos detalhes legais, entendeu que a Presidente havia acatado seu pedido de veto. Entretanto, os autores do abaixo assinado, com aproximadamente 2 (dois) milhões de assinaturas ${ }^{90}$, desejavam o veto integral do nefasto projeto de lei que culminou na atual legislação sobre vegetação nativa, Lei federal 2.651/2012. Ressalte-se que a sanção presidencial à lei ambiental mais retrocessiva de que se tem notícia ocorreu poucas semanas antes da Rio+20, Conferência Mundial das Nações Unidas sobre desenvolvimento sustentável, sediada no Rio de Janeiro.

\footnotetext{
${ }^{90}$ AQUINO, Yara. ONG encaminha ao governo abaixo-assinado que pede veto total ao Código Florestal. Disponível em <http://memoria.ebc.com.br/agenciabrasil/noticia/2012-05-24/ongencaminha-ao-governo-abaixo-assinado-que-pede-veto-total-ao-codigo-florestal $>$ Acesso em 20 de out. de 2015.
} 
A Lei aprovada deve ser analisada em conjunto com o Decreto federal 7.830/2012, que dispõe sobre o Cadastro Ambiental Rural e os Programas de Regularização Ambiental, novos instrumentos previstos no Código Florestal atual; o Decreto federal 8.265/2014; que estabelece regras complementares aos Programas de Regularização da nova lei; e a Instrução Normativa 2/2014, do Ministério do Meio Ambiente, que dispõe sobre os procedimentos do Cadastro Ambiental Rural a nível federal. Este conjunto normativo alterou substancialmente a legislação ambiental e gerou muitos debates acerca da criação das chamadas áreas rurais consolidadas, a determinação de um marco temporal para possível anistia de infrações ambientais, a modificação do regime de utilização das áreas de preservação permanente e reserva legal, entre outros aspectos espinhosos que têm sido analisados.

Antes da análise específica dos dispositivos mais criticados e que poderiam ser caracterizados como retrocessivos e inconstitucionais, é importante perceber que, de uma maneira geral, a nova Lei afronta a Constituição.

A atual legislação enfraqueceu institutos como da reserva legal e das áreas de preservação permanente ao aumentar o rol dos casos nos quais tais áreas especialmente protegidas podem ser utilizadas.

A legislação de 1965 havia sido recepcionada pela Constituição de 1988 que confirmou, em seu artigo 225, a tônica protetiva do meio ambiente, consagrando o direito fundamental ao meio ambiente ecologicamente equilibrado, como explicitado anteriormente neste trabalho. A Constituição fez, ainda, referências explícitas à necessidade de preservação e restauração dos processos ecológicos essenciais (artigo 225, $\S 1^{\circ}$, I), o dever do Poder Público de definir os espaços territoriais especialmente protegidos e de proteção da fauna e da flora, vedando práticas que coloquem em risco sua função ecológica (artigo $225, \S 1^{\circ}$, III e VII). 
Como tem sido constantemente analisado, a nova legislação de florestas estabelece de forma geral um padrão de proteção ambiental inferior em relação à legislação de 1965. Nas Ações Diretas de Inconstitucionalidade 4901, 4902 e 4903 propostas pelo Ministério Público Federal, afirma-se que as afrontas à Constituição consubstanciam-se em diversos dispositivos da nova Lei, sejam eles sobre reservas legais, áreas de preservação permanente ou sobre os deveres de proteção atribuídos ao Poder Público. Neste sentido, demonstra-se que as alterações empreendidas comprometem os dispositivos constitucionais mencionados, frustrando os processos ecológicos essenciais, a função ecológica da fauna e da flora e o dever de restaurar integralmente os danos causados ${ }^{91}$. Da inicial da ADI 4901, destaca-se:

Além de afrontar os deveres fundamentais, as normas impugnadas violam o princípio da vedação de retrocesso social, pois, de forma geral, estabelecem um padrão de proteção ambiental manifestamente inferior ao anteriormente existente, (...) Além da diminuição direta dos padrões de proteção, decorrente da diminuição dos espaços efetivamente protegidos e dos prejuízos às funções ecológicas das reservas legais, merece especial atenção dessa Corte Constitucional a sem precedentes fragilização dos instrumentos de proteção ambiental e a autorização para consolidação dos danos ambientais já perpetrados, ainda que praticados com afronta à legislação anteriormente vigente. ${ }^{92}$.

Além disso, é possível perceber que os dispositivos da Lei impugnada afrontam o artigo 225 da Constituição Federal, violando o dever geral de proteção e a obrigação de reparação integral dos danos ambientais causados $^{93}$.

Neste trabalho, não se pretende fazer uma análise exaustiva da Lei 12.651/2012. No entanto, além de destacar que, de um modo geral, a Lei estabelece padrões de proteção inferiores aos que existiam com a revogada Lei 4.771/1965, serão apontados alguns dispositivos que claramente indicam o seu caráter retrocessivo e, portanto, inconstitucional.

\footnotetext{
91 STF, ADI n. 4901, Rel. Ministro Luiz Fux. Petição Inicial ajuizada pelo Ministério Público Federal, em 18 jan. 2013. Pendente de julgamento. p 11.

92 STF, ADI n. 4901, Rel. Ministro Luiz Fux. Petição Inicial ajuizada pelo Ministério Público Federal, em 18 jan. 2013. Pendente de julgamento. p 12.

${ }^{93}$ Neste sentido, Ações Diretas de Inconstitucionalidade 4901, 4902 e 4903.
} 
Para isso, é necessário explicar o que são as áreas de preservação permanente e de reserva legal, sua relevância ecológica, além da definição de área rural consolidada, fruto de inovação da Lei 12.651/2012, previstas no artigo $3^{\circ}$, II, III e IV e que foram alvo de importantes alterações e retrocessos.

\subsection{Interpretação da nova lei à luz do princípio da vedação ao retrocesso socioambiental}

\subsection{1 Área Rural Consolidada}

Fruto de inovação legislativa, a área rural consolidada é um dos pontos mais controvertidos da Lei 12.651/2012, sendo alvo de crítica dos jus-ambientalistas e da comunidade científica de modo geral. Encontra-se definida no artigo $3^{\circ}$, IV, da Lei 12.651/2012:

Área rural consolidada: área de imóvel rural com ocupação antrópica preexistente a 22 de julho de 2008, com edificações, benfeitorias ou atividades agrossilvipastoris, admitida, neste último caso, a adoção do regime de pousio; $;{ }^{94}$

São, portanto, áreas rurais consolidadas aquelas ocupadas irregularmente entre a entrada em vigor do Código Florestal de 1965 e a data estipulada acima, que corresponde à edição do Decreto 6.514, de 22 de julho de 2008, que regulamentou as infrações ambientais previstas na Lei de Crimes Ambientais, Lei federal 9.605/1998.

São, portanto, áreas rurais consolidadas aquelas ocupadas irregularmente entre a entrada em vigor do Código Florestal de 1965 e a data estipulada acima, que corresponde à edição do Decreto 6.514, de 22 de julho de 2008, que regulamentou as infrações administrativas ambientais previstas na Lei de Crimes Ambientais, Lei federal 9.605/1998.

O referido Decreto é tido como o grande impulsionador da reforma do Código Florestal, já que regulamenta as multas e sanções decorrentes 
das infrações previstas na Lei de Crimes Ambientais. No entanto, já havia o Decreto federal 3.179/1999, que regulamentava a mesma matéria. A escolha da data de 22 de julho de 2008 não corresponde ao início da aplicação de multas e sanções ante a Lei de Crimes Ambientais e seu decreto regulamentador. Trata-se, portanto, de evidente escolha política com vistas à regularização das ocupações irregulares (em desconformidade com o Código Florestal vigente à época), que veio a suspender as sanções decorrentes de infrações cometidas antes de 22 de julho de 2008, mediante cadastro da propriedade no Cadastro Ambiental Rural (CAR) e assinatura de termo de compromisso, de acordo com o artigo 59, parágrafos $4^{\circ}$ e $5^{\circ}$, da Lei 12.651/2012.

Por conseguinte, as áreas rurais consolidadas criam dois regimes jurídicos diferentes, de acordo com a época na qual houve a ocupação com atividades agrossilovipastoris. Passam a ser exigidos parâmetros diferenciados relacionados às áreas de preservação permanente e de reserva legal, como será analisado em seguida.

As áreas consolidadas estão descritas no capítulo das disposições transitórias em duas seções referentes às áreas de preservação permanente e reserva legal, seções II e III, respectivamente, embora possamos encontrar o marco temporal de 22 de julho de 2008 mencionado 23 vezes ao longo do texto legal.

A anistia permitida através da positivação desse marco temporal gera o que se poderia chamar de dois regimes jurídicos diferenciados perante a lei. Aqueles que a descumpriram a legislação até julho de 2008 não serão punidos e terão obrigações diferenciadas e menos restritivas em relação à recomposição da área; aqueles que cumpriram, ou seja, cujos imóveis não se encontram enquadrados como áreas rurais consolidadas, terão um regime mais rígido e voltado à proteção das áreas de preservação permanente e reservas legais. Isso vai de encontro com o princípio da isonomia e gera

\footnotetext{
${ }^{94}$ Art. $3^{\circ}$, IV, da Lei federal 12.651, de 25 de maio de 2012.
} 
extrema insegurança jurídica, além de ser um estímulo à desobediência civil, pelo fato de que seja plausível esperar que um novo marco temporal seja determinado futuramente, com a mesma finalidade ${ }^{95}$.

Quanto à problemática da anistia ambiental, Silveira descreve os efeitos desse "perdão":

Ocorre que nem a política passa à margem da lei e há efeitos perniciosos decorrentes de um perdão, pois a) equipara a posteriori aqueles que cumpriram a lei com aqueles que a infringiram, violando-se a igualdade; b) retira a força da regra - e esse é um dos sentidos de um sistema normativo, deslegitimando o seu conteúdo, igualando negativamente os desiguais, e, por consequência, propiciando a insegurança jurídica; mas, sobretudo, c) leva para o esquecimento dos arquivos a gravidade do fato ocorrido. Que em termos ambientais significa desinformação sobre dano, perigo e necessários cuidados e d) aprofunda o sentimento de impunidade tão arraigado em nossa cultura. ${ }^{96}$.

Para ela, a anistia ambiental é uma ameaça ao Estado Socioambiental de Direito, além de inconstitucional e grave retrocesso ambiental ${ }^{97}$.

Por fim, destaca-se que a nova legislação institui o Cadastro Ambiental Rural (CAR) que, de acordo com artigo 29, caput, é um registro público feito por meio eletrônico, de abrangência nacional e obrigatório para todos os imóveis rurais. De acordo com o art. 29, § $1^{\circ}$, III, o proprietário poderá identificar, no momento da inscrição no CAR, as áreas rurais consolidadas, possibilitando que o proprietário ou possuidor se desobrigue do pagamento de multas pecuniárias e da punibilidade de crimes previstos nos artigos 38, 39 e 48 da Lei de Crimes Ambientais (Lei federal 9.605/1998). O cadastro no CAR e posterior adequação aos Programas de Regularização Ambiental possibilitam ao proprietário ou possuidor não serem autuados por infrações cometidas antes do marco temporal de 22 de julho de 2008.

\footnotetext{
${ }^{95}$ SILVEIRA, Patrícia Azevedo. A Anistia Ambiental como ameaça ao Estado Socioambiental de Direito. In: LAVRATTI, Paula; BUZELATO, Vanêsca Prestes. Direito e mudanças climáticas [recurso eletrônico: reforma do Código Florestal: limites jurídicos]. São Paulo: Instituto O Direito por um Planeta Verde, 2010.

${ }^{96}$ SILVEIRA, Patrícia Azevedo. A Anistia Ambiental como ameaça ao Estado Socioambiental de Direito. p. 117.

${ }^{97}$ SILVEIRA, Patrícia Azevedo. A Anistia Ambiental como ameaça ao Estado Socioambiental de Direito. p. 133.
} 
A compreensão desse novo instituto é essencial para o entendimento dos retrocessos criados no âmbito das áreas de preservação permanente e de reserva legal, como se verá em seguida.

\subsection{2. Área de preservação permanente}

A área de preservação permanente está conceituada no artigo $3^{\circ}$, II, da Lei 12.651/2012:

Área de Preservação Permanente - APP: área protegida, coberta ou não por vegetação nativa, com a função ambiental de preservar os recursos hídricos, a paisagem, a estabilidade geológica e a biodiversidade, facilitar o fluxo gênico de fauna e flora, proteger o solo e assegurar o bem-estar das populações humanas;

Sua delimitação e rol taxativo encontram-se no artigo $4^{\circ}$, I a XI. São consideradas área de preservação permanente: (i) as faixas marginais de qualquer curso d'água natural perene e intermitente, excluídos os efêmeros, desde a borda da calha do leito regular; (ii) as áreas no entorno dos lagos e lagoas naturais; (iii) as áreas no entorno dos reservatórios d'água artificiais, decorrentes de barramento ou represamento de cursos d'água naturais; (iv) as áreas no entorno das nascentes e dos olhos d'água perenes; (v) as encostas ou partes destas com declividade superior a $45^{\circ}$; (vi) as restingas; (vii) os manguezais; (viii) as bordas dos tabuleiros ou chapadas; (ix) os topos de morros, montes, montanhas e serras; (x) as áreas em altitude superior a 1.800 (mil e oitocentos) metros; e (xi) as veredas.

A nível científico, a Sociedade Brasileira para o Progresso da Ciência (SBPC) e a Academia Brasileira de Ciências assim definem o papel e importância das áreas de preservação permanente:

Entre os pesquisadores, há consenso de que as áreas marginais a corpos d'água sejam elas várzeas ou "florestas ripárias - e os topos de morro ocupados por campos de altitude ou rupestres são áreas insubstituíveis em razão da biodiversidade e de seu alto grau de especialização e endemismo, além dos serviços ecossistêmicos essenciais que desempenham - tais como a regularização hidrológica, a estabilização de encostas, a manutenção da população de polinizadores e de ictiofauna, o controle natural de pragas, das doenças e das espécies exóticas invasoras. Na zona ripária, além do abrigo da biodiversidade com seu provimento de serviços ambientais, os solos úmidos e sua vegetação nas zonas de influência de rios e lagos são ecossistemas de reconhecida importância 
na atenuação de cheias e vazantes, na redução da erosão superficial, no condicionamento da qualidade da água e na manutenção de canais pela proteção de margens e redução do assoreamento. Existe amplo consenso científico de que são ecossistemas que, para sua estabilidade e funcionalidade, precisam ser conservados ou restaurados, se historicamente degradados. Quando ecossistemas naturais maduros ladeiam os corpos d'água e cobrem os terrenos com solos hidromórficos associados, o carbono e os sedimentos são fixados, a água em excesso é contida, a energia erosiva de correntezas é dissipada e os fluxos de nutrientes nas águas de percolação passam por filtragem química e por processamento microbiológico, o que reduz sua turbidez e aumenta sua pureza. A eficiência dessas faixas de vegetação remanescentes depende de vários fatores, entre eles a largura e o estado de conservação da vegetação preservada e o tipo de serviço ecossistêmico considerado, incluindo-se, na sua avaliação, o papel das áreas ribeirinhas na conservação da biodiversidade. Um ganho marginal para os proprietários das terras na redução da vegetação nessas áreas pode resultar num gigantesco ônus para a sociedade como um todo, especialmente, para a população urbana que mora naquela bacia ou região. Mesmo com toda a evolução do conhecimento científico e tecnológico, os custos para restaurar as áreas mais degradadas são ainda muito elevados, especialmente no caso das várzeas. Além do mais, nem todos os serviços ecossistêmicos são plenamente recuperados. ${ }^{98}$ (grifo nosso)

Inobstante a relevância das áreas de preservação permanente, afirmada pela comunidade científica, a nova legislação florestal criou situações de utilização que frustram o desempenho de sua da função ecológica, descaracterizam a área e por isso diversos dispositivos são considerados retrocessivos e inconstitucionais. As ações diretas de inconstitucionalidade ajuizadas pelo Ministério Público Federal - ADI 490199, ADI $4902^{100}$ e ADI $4903^{101}$ suscitaram as seguintes inconstitucionalidades materiais no que tange às áreas de preservação permanente: (i) inconstitucionalidade da permissão de novos desmatamentos sem que haja recuperação dos já realizados irregularmente (art. $7^{\circ}, \S 3^{\circ}$ ); (ii) retrocesso quanto à largura das faixas de proteção das áreas de preservação permanente dos cursos d'água (art. 3º XIX); (iii) inconstitucionalidade dos dispositivos que permitem a consolidação de danos ambientais decorrentes de infrações à legislação de proteção às áreas

\footnotetext{
${ }^{98}$ SILVA, José Antonio Aleixo da et al.. O Código Florestal e a Ciência: Contribuições para o Diálogo. São Paulo: Sociedade Brasileira para o Progresso da Ciência, SBPC; Academia Brasileira de Ciências, ABC, 2011.p. 12.

99 STF, ADI n. 4901, Rel. Ministro Luiz Fux. Petição Inicial ajuizada pelo Ministério Público Federal, em 18 jan. 2013. Pendente de julgamento.

${ }^{100}$ STF, ADI n. 4901, Rel. Ministro Luiz Fux. Petição Inicial ajuizada pelo Ministério Público Federal, em 18 jan. 2013. Pendente de julgamento.
} 
de preservação permanentes, praticados até 22 de julho de 2008 (arts. 61-A, 61-B, 61-C e 63); (iv) intervenções em áreas de preservação permanente na hipótese de utilidade pública e interesse social (art. $3^{\circ}$, VIII e IX, art. $4^{\circ}$, § $6^{\circ}$ e $8^{\circ}$ ); (v) previsão normativa acerca das atividades de aquicultura em área de preservação permanente $\left(\operatorname{art.} 4^{\circ}, \S 6^{\circ}\right)$; (vi) intervenções em mangues e restingas (art. $8^{\circ}, \S 2^{\circ}$ ); (vii) uso agrícola das várzeas (art. $4^{\circ}, \S 5^{\circ}$ ); (viii) diminuição da proteção das nascentes e olhos d'água (art. 2, “c”); (ix) diminuição da proteção da áreas de preservação permanente em reservatórios artificiais (art. $2^{\circ}$, "b", art. $4^{\circ}, \S \S 1^{\circ}$ e $4^{\circ}$, art. $5^{\circ}$ ); e (x) retrocesso ambiental quanto à proteção das áreas com inclinação entre $25^{\circ} \mathrm{e}$ $45^{\circ}$ (art. 10).

Neste trabalho não serão analisadas todas as questões levantadas pelas ações diretas de inconstitucionalidade. Foram escolhidos alguns dispositivos para análise legal e empírica, à luz do princípio da vedação ao retrocesso socioambiental, especificamente aqueles que diminuíram os parâmetros de proteção das áreas de preservação permanente e reserva legal e aqueles que extinguiram certas categorias desses espaços territoriais especialmente protegidos.

A Lei federal 12.651/2012 criou um novo regime jurídico para as áreas rurais consolidadas em áreas de preservação permanente e áreas de reserva legal. Os parâmetros de proteção são mais flexíveis para aqueles que descumpriram a lei anterior e desmataram os espaços protegidos mencionados, consolidando sua ocupação com atividades agrossilvipastoris, de ecoturismo, turismo rural, sua infraestrutura e respectivo acesso, além da manutenção de residências, de acordo com o artigo 61-A, § 12. No entanto, para aqueles que cumpriram a lei anterior e para os desmatamentos realizados após 22 de julho de 2008, os parâmetros continuam os mesmos da legislação anterior. Como se observa em relação aos cursos d'água na tabela abaixo:

${ }^{101}$ STF, ADI n. 4903, Rel. Ministro Luiz Fux. Petição Inicial ajuizada pelo Ministério Público 


\begin{tabular}{|c|c|c|c|}
\hline & $\begin{array}{l}\text { Lei federal } \\
4.771 / 2012 \\
\text { Art. 2o "a" }\end{array}$ & $\begin{array}{c}\text { Lei federal } \\
12.651 / 2012 \\
\text { (Propriedades que não } \\
\text { possuem área rural } \\
\text { consolidada ou } \\
\text { desmatamentos } \\
\text { realizados após } 22 \text { de } \\
\text { julho de 2008) } \\
\text { Art. } 4^{\circ}, \text { I e alíneas }\end{array}$ & $\begin{array}{c}\text { Lei federal } \\
12.651 / 2012 \\
\text { (Propriedades com área } \\
\text { rural consolidada) } \\
\\
\text { Art. } 61-\mathrm{A}, \S 1^{\circ} \text { a } \S 4^{\circ} \text {; } \\
\text { Dec. fed. } 7830 / 2012, \\
\text { art. } 19, \S 4^{\circ}, \text { I e II }\end{array}$ \\
\hline $\begin{array}{c}\text { APP de } \\
\text { cursos d'água }\end{array}$ & $\begin{array}{l}30 \text { (trinta) metros } \\
\text { para os cursos d'água } \\
\text { de menos de } 10 \text { (dez) } \\
\text { metros de largura } \\
50 \text { (cinquenta) metros } \\
\text { para os cursos d'água } \\
\text { que tenham de } 10 \\
\text { (dez) a } 50 \text { (cinquenta) } \\
\text { metros de largura } \\
100 \text { (cem) metros } \\
\text { para os cursos d'água } \\
\text { que tenham de } 50 \\
\text { (cinquenta) a } 200 \\
\text { (duzentos) metros de } \\
\text { largura; } \\
200 \text { (duzentos) } \\
\text { metros para os cursos } \\
\text { d'água que tenham de } \\
200 \text { (duzentos) a } 600 \\
\text { (seiscentos) metros } \\
\text { de largura; } \\
500 \text { (quinhentos) } \\
\text { metros para os cursos } \\
\text { d'água que tenham } \\
\text { largura superior a } 600 \\
\text { (seiscentos) metros }\end{array}$ & $\begin{array}{l}30 \text { (trinta) metros, para } \\
\text { os cursos d'água de } \\
\text { menos de } 10 \text { (dez) } \\
\text { metros de largura; } \\
50 \text { (cinquenta) metros, } \\
\text { para os cursos d'água } \\
\text { que tenham de } 10 \text { (dez) } \\
\text { a } 50 \text { (cinquenta) metros } \\
\text { de largura; } \\
100 \text { (cem) metros, para } \\
\text { os cursos d'água que } \\
\text { tenham de } 50 \\
\text { (cinquenta) a } 200 \\
\text { (duzentos) metros de } \\
\text { largura; } \\
\text { 200 (duzentos) metros, } \\
\text { para os cursos d'água } \\
\text { que tenham de } 200 \\
\text { (duzentos) a } 600 \\
\text { (seiscentos) metros de } \\
\text { largura; } \\
\text { 500 (quinhentos) } \\
\text { metros, para os cursos } \\
\text { d'água que tenham } \\
\text { largura superior a } 600 \\
\text { (seiscentos) metros; }\end{array}$ & 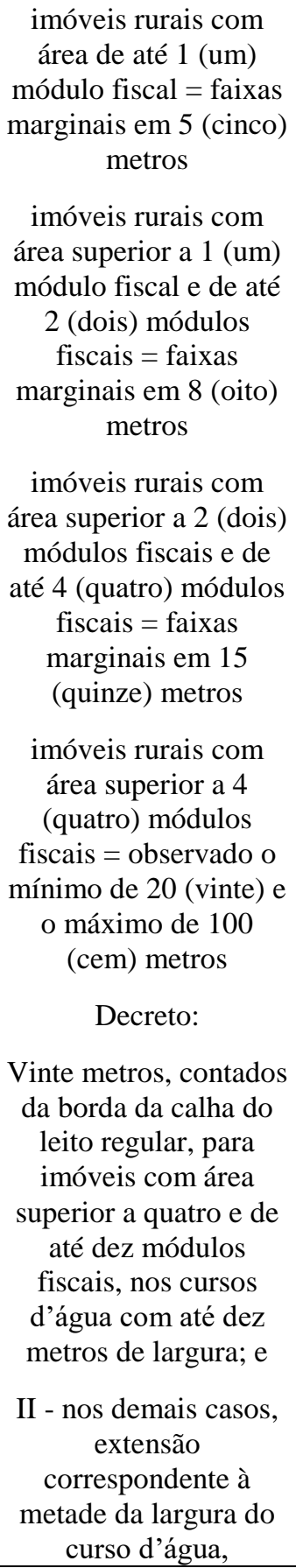 \\
\hline
\end{tabular}

Federal, em 18 jan. 2013. Pendente de julgamento. 


\begin{tabular}{|l|l|l|}
\hline & & $\begin{array}{c}\text { observado o mínimo de } \\
\text { trinta e o máximo de } \\
\text { cem metros, contados } \\
\text { da borda da calha do } \\
\text { leito regular. }\end{array}$ \\
\hline
\end{tabular}

No que se refere à largura das áreas de preservação permanente dos cursos d'água, os parâmetros da nova lei para áreas consolidadas são consideravelmente menores e, de acordo com o artigo $4^{\circ}$, I, e artigo 61-A, parágrafos $1^{\circ}$ a $4^{\circ}$, a APP é medida a partir da borda da calha do leito regular do curso d'água, diferentemente da lei anterior que previa a medida a partir do seu nível mais alto (art. 2º "a”, Lei federal 4.771/1965). Tal mudança do ponto a partir do qual a APP dos cursos d’água é medida resultou também na redução de seu tamanho, o que, na opinião da comunidade científica, resulta em perdas significativas da proteção dos biomas brasileiros, como se depreende do excerto abaixo:

Uma possível alteração na definição da APP ripária, do nível mais alto do curso d'água - conforme determina o Código Florestal vigente - para a borda do leito menor, como é proposto no substitutivo, representaria grande perda de proteção para áreas sensíveis. Essa alteração proposta no bordo de referência significaria perda de até $60 \%$ de proteção para essas áreas na Amazônia, por exemplo. Já a redução da faixa ripária de 30 para $15 \mathrm{~m}$ nos rios com até $5 \mathrm{~m}$ de largura, que compõem mais de $50 \%$ da rede de drenagem em extensão, resultaria numa redução de $31 \%$ na área protegida pelas APPs ripárias. Estudo recente constatou que as APPs ripárias representam, de acordo com o Código em vigor, somente $6,9 \%$ das áreas privadas. ${ }^{102}$

As diferenças nas dimensões das APP de cursos d’água em razão das mudanças na forma de medição podem ser facilmente observadas na figura abaixo, que considera o exemplo de um curso d’água de menos de dez metros de largura:

${ }^{102}$ SILVA, José Antonio Aleixo da et al.. O Código Florestal e a Ciência: Contribuições para o Diálogo. p. 12-13 


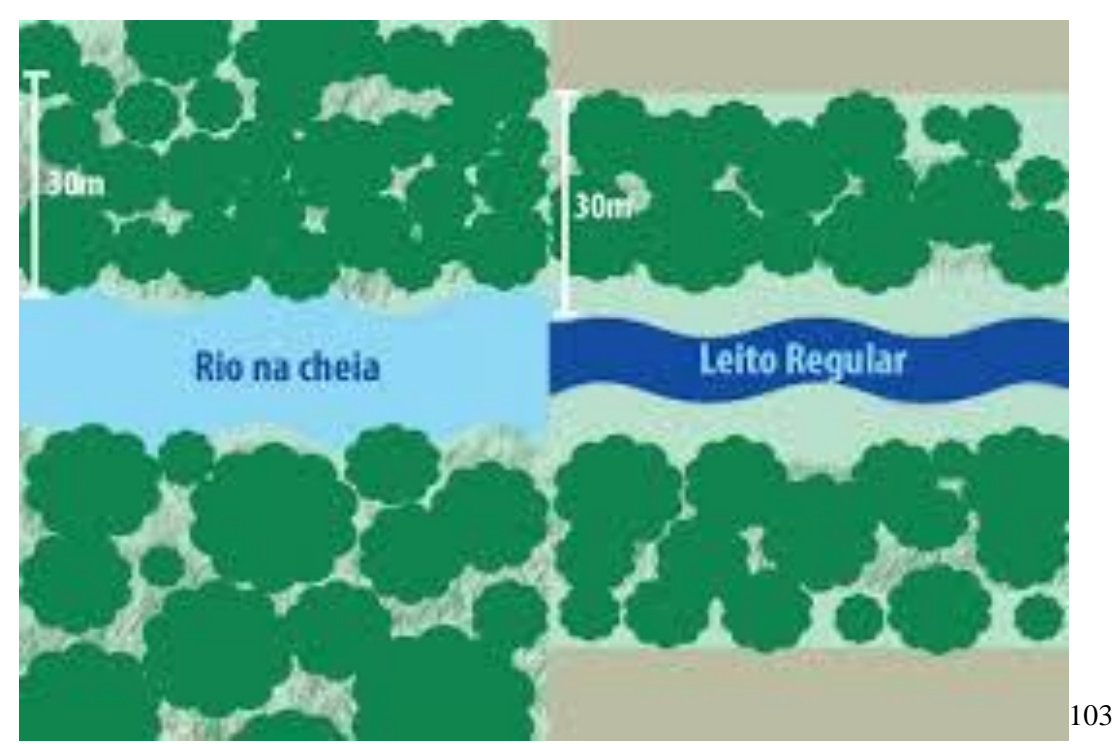

Ainda de acordo com a comunidade científica, dentre os fatores relacionados à eficiência das APP ripárias, o mais importante seria justamente a largura ${ }^{104}$, por isso entende-se que tal diminuição representa um retrocesso ambiental por tratar-se de um padrão que já estava consolidado no direito e que atinge o núcleo essencial do direito fundamental ao meio ambiente ecologicamente equilibrado, na medida em que tem relação direta com os processos ecológicos essenciais desenvolvidos em tais áreas.

APP de cursos d'água têm relação direta com sua largura, o que nas áreas rurais consolidadas não será observado à luz do previsto na Lei 12.651/2012. A largura dependerá do tamanho do imóvel - medido em módulos fiscais ${ }^{105}$ - e não de acordo com a largura do curso d'água, o que, técnica e cientificamente, não faz sentido, diminui drasticamente a cobertura das áreas frágeis que devem ser protegidas. Dessa forma, as APP

\footnotetext{
${ }^{103}$ Imagem extraída do seguinte documento: SOARES, Nana; SANTOS, Juliana Mendonça. Professores afirmam que Novo Código Florestal ameaça biomas. Disponível em $<$ http://alfonsin.com.br/professores-afirmam-que-novo-cdigo-florestal-ameaa-biomas/> Acesso em 20 out. 2015.

${ }^{104}$ LIMA, André; BENSUSAN, Nurit; RUSS, Lian. Código Florestal: por um debate pautado em ciência. p. 5.

${ }^{105}$ Módulos fiscais são unidades de medida definidas pelo INCRA são definidos de acordo com o município onde estão localizados. Medidos em hectares, podem variar de 50 a 110 hectares. O imóvel de até 4 (quatro) módulos fiscais, que recebe isenções e benefícios de acordo com o Código Florestal, pode representar uma propriedade de 20 ha até 440 ha. O que significa que, dependendo do município onde esteja localizado, um imóvel menor do que 4 (quatro) módulos fiscais pode corresponder a uma grande propriedade.
} 
ao longo de um mesmo rio serão completamente dessemelhantes, dificultando a formação dos corredores ecológicos e o endemismo esperado da área em questão

Como se observa na imagem abaixo, um mesmo rio é ladeado por APP de tamanhos totalmente diferentes que tem relação com o tamanho da propriedade na qual se inserem e não com o curso d'água que protegem:

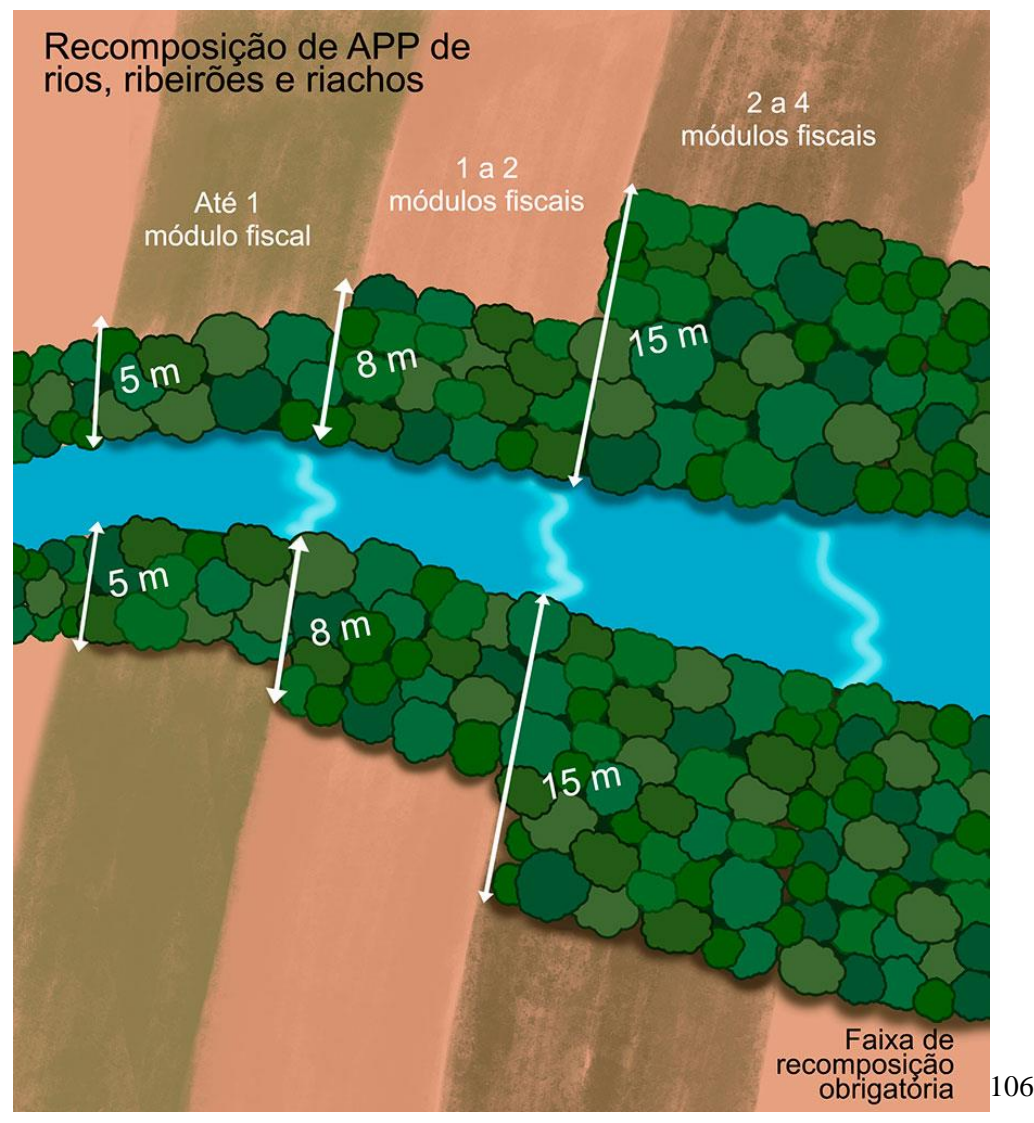

Importante ressaltar que, mesmo a lei anterior deveria ser aprimorada, num sentido de progressivo aumento da proteção do meio ambiente, o que depende totalmente dos aspectos de cada área especificamente considerada, como se lê abaixo:

A extensão ideal de áreas de preservação permanente ao longo dos cursos d'água varia de acordo com sua função, localização, características geológicas e características da bacia hidrográfica. Por exemplo, Silva Junior (2001) afirma que são necessárias APP de 80 metros no Cerrado, se o objetivo é garantir a proteção da composição florística, enquanto Marco e Coelho (2004) defendem uma

\footnotetext{
106 Imagem extraída do seguinte documento: Centro de Inteligência em Florestas. Cartilha do Código Florestal Brasileiro. Disponível em < http://www.ciflorestas.com.br/cartilha/APP-o-quedeve-ser-recomposto-nas-areas-rurais-consolidadas.html > Acesso em 20 out. 2015.
} 
extensão de 200 metros para a preservação de habitats de aves e mamíferos. Quando se trata de APP em áreas urbanas, parâmetros devem ser estabelecidos para regrar a ocupação humana e evitar desastres, principalmente em áreas com declive acentuado. As observações empíricas (por exemplo, Schaffer et al., 2011) e os estudos (por exemplo, Ackerman, 2010; Augusto Filho, 2001; Farah, 2003; Rodrigues e Leitão Filho, 2000; e Zucco et al., 2011) mostram que, como princípio, deveria haver restrições de uso nos vales das cabeceiras de drenagem, que funcionariam como áreas de estocagem de águas e de estabilização das encostas. ${ }^{107}$

Para ilustrar a questão relativa à diminuição dos parâmetros de proteção das APP de cursos d'água e suas implicações práticas, serão apresentadas três imagens do Rio Grande, curso d'água presente no Município de Nova Friburgo, um dos locais mais afetados pelo desastre natural do dia 12 de janeiro de 2011, no qual a região serrana do Estado do Rio de Janeiro sofreu com enchentes e deslizamentos nos inúmeros morros da região. De acordo com o Anuário Brasileiro de Desastres Naturais ${ }^{108}$, de 2011, considera-se como o maior desastre natural já registrado no Brasil, tendo afetado os Municípios de Nova Friburgo, Petrópolis, Teresópolis e Sumidouro e provocado 918 mortes oficialmente registradas, levando-se em conta que o número de desaparecidos é até hoje desconhecido.

A primeira imagem é um recorte do mencionado curso d'água antes do desastre, em 07 de outubro de 2010. A segunda imagem foi capturada sete dias após os deslizamentos e enchentes, em 19 de janeiro de 2011. Observa-se a invasão do curso d'água sobre diversas construções e a total devastação da área.

\footnotetext{
${ }^{107}$ LIMA, André; BENSUSAN, Nurit; RUSS, Lian. Código Florestal: por um debate pautado em ciência. p. 16-17.

${ }^{108}$ PEIXOTO FILHO, Getúlio Ezequiel da. et al.. Anuário brasileiro de desastres naturais: 2011. Centro Nacional de Gerenciamento de Riscos e Desastres. Brasília: CENAD, 2012. p. 63. Disponível em <http://www.mi.gov.br/c/document_library/get_file?uuid=e3cab906-c3fb-49fa945d-649626acf790\&groupId=185960> Acesso em 07 nov. 2015.
} 

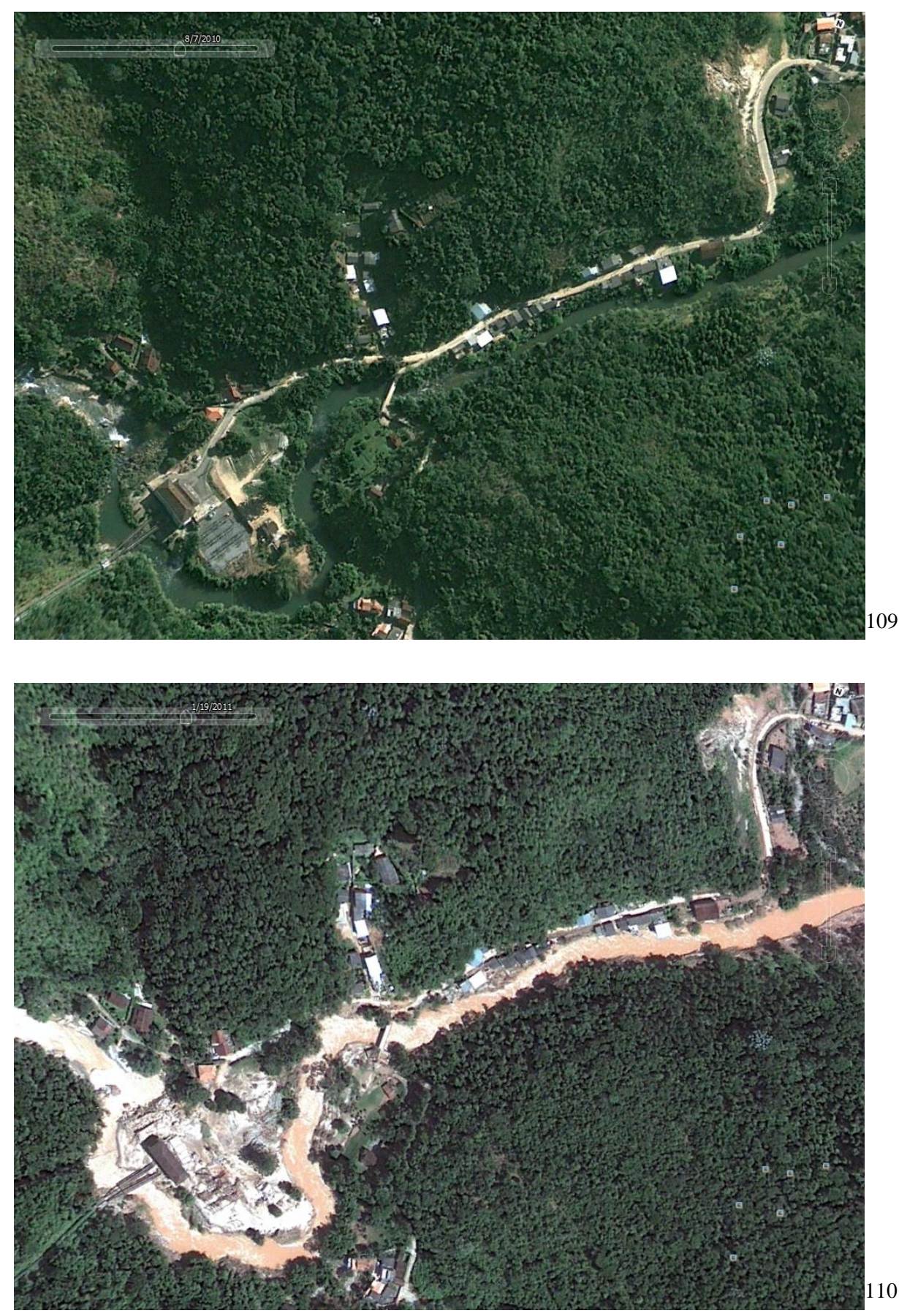

Finalmente, apresenta-se uma terceira imagem na qual foram inseridos os parâmetros atuais de APP de cursos d'água em áreas consolidadas, cuja demarcação pelo geógrafo VICTORIO, considera hipoteticamente o imóvel no qual estaria inserido o rio para traçar as diferentes faixas de APP previstas.

\footnotetext{
${ }^{109}$ Imagem extraída do Google Earth, correspondente ao dia 07 out. 2010.

${ }^{110}$ Imagem extraída do Google Earth, correspondente ao dia 19 jan. 2011.
} 
As linhas coloridas correspondem às APP em área consolidada, de acordo com o artigo 61-A, parágrafos $1^{\circ}$ a $4^{\circ}$, da Lei $12.651 / 2012$ e artigo $19, \S 4^{\circ}, \mathrm{I}$ do Decreto federal 7.830/2012. A linha verde corresponde à faixa de 5 (cinco) metros prevista para imóveis de até 1 (um) módulo fiscal; a linha amarela corresponde à faixa de 8 (oito) metros prevista para os imóveis de até 2 (dois) módulos fiscais; a linha laranja corresponde à faixa de 15 (quinze) metros) prevista para imóveis entre 2 (dois) e 4 (quatro) módulos fiscais; e a linha vermelha corresponde a uma faixa de 20 (vinte) metros prevista para imóveis entre 4 (quatro) e 10 (dez) módulos fiscais.

Nota-se que há construções dentro de todos os parâmetros analisados e que estes são absolutamente insuficientes como limites mínimos de largura. Verifica-se, portanto, a inadequação da legislação atual em relação à realidade fática do rio em questão. Os parâmetros legais consolidados são úteis apenas para resolver os problemas relacionados aos passivos ambientais em áreas protegidas, mas ignoram completamente a finalidade da APP, neste caso não apenas voltada às suas funções ecológicas intrínsecas, mas diretamente relacionada com a proteção das vidas humanas ali presentes. 


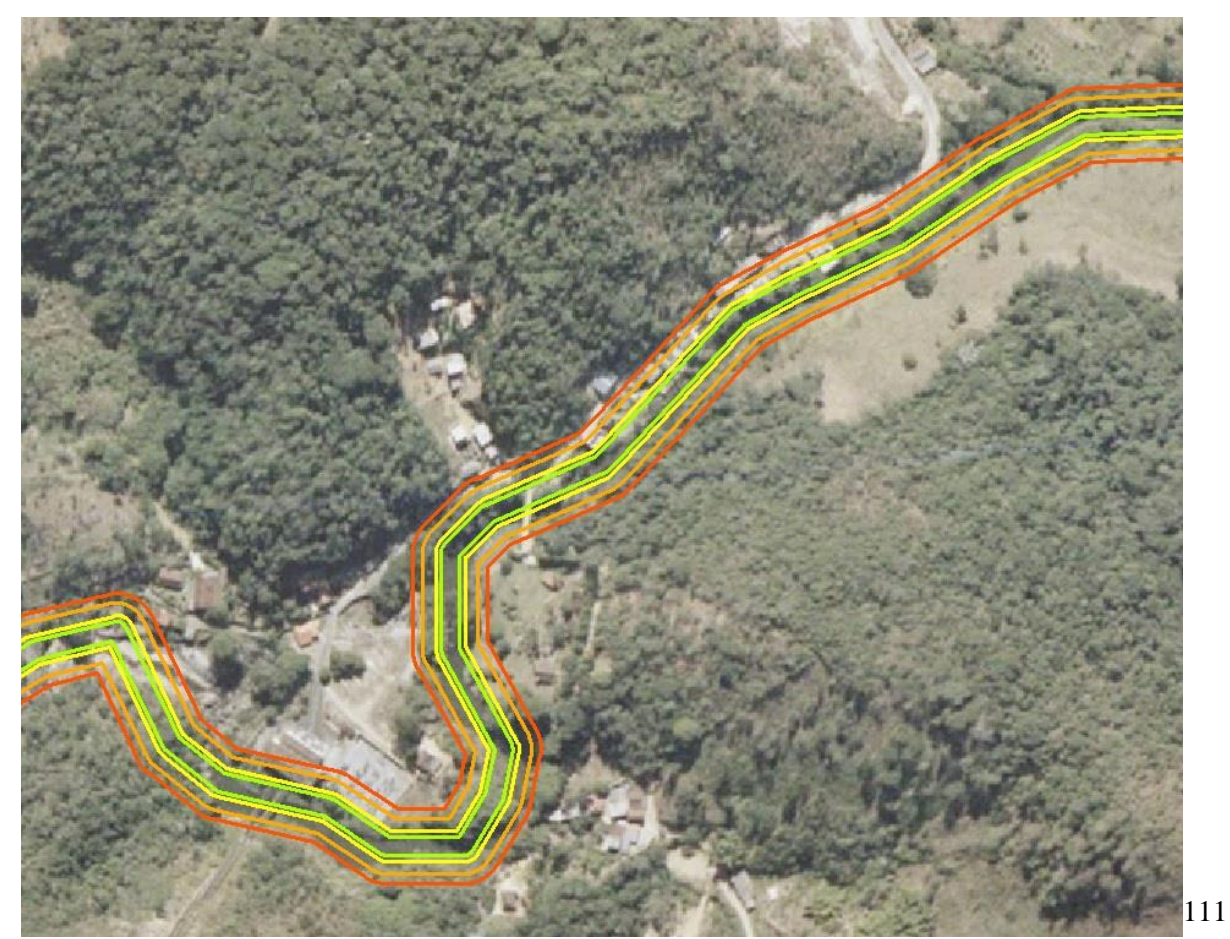

Da mesma forma, as APP de lagos e lagoas tiveram seus parâmetros de proteção drasticamente diminuídos e relacionados ao tamanho da propriedade na qual se inserem, de acordo com o artigo 61-A, $\S 6^{\circ}$ da nova Lei. Como se observa na tabela abaixo:

\begin{tabular}{|c|c|c|c|}
\hline & $\begin{array}{l}\text { Lei federal } \\
4.771 / 2012\end{array}$ & $\begin{array}{l}\text { Lei federal } \\
12.651 / 2012 \\
\text { (Propriedades que } \\
\text { não possuem área } \\
\text { rural consolidada ou } \\
\text { desmatamentos } \\
\text { realizados após } 22 \text { de } \\
\text { julho de 2008) }\end{array}$ & $\begin{array}{c}\text { Lei federal } \\
12.651 / 2012 \\
\text { (Propriedades com } \\
\text { área rural } \\
\text { consolidada) }\end{array}$ \\
\hline & $\begin{array}{l}\text { Art. 20, "b”; Res. } \\
\text { Conama 303/2002. }\end{array}$ & Art. 4, II, "a" e "b" & Art. 61-A, $\S 6^{\circ}$ \\
\hline $\begin{array}{c}\text { APP de lagos e } \\
\text { lagoas }\end{array}$ & $\begin{array}{l}30 \text { (trinta) metros, } \\
\text { para os que estejam } \\
\text { situados em áreas } \\
\text { urbanas consolidadas; } \\
100 \text { (cem) metros, } \\
\text { para as que estejam }\end{array}$ & $\begin{array}{l}30 \text { (trinta) metros, em } \\
\text { zonas urbanas; } \\
100 \text { (cem) metros, em } \\
\text { zonas rurais, exceto } \\
\text { para o corpo d'água }\end{array}$ & $\begin{array}{l}5 \text { (cinco) metros, para } \\
\text { imóveis rurais com } \\
\text { área de até } 1(\mathrm{um}) \\
\text { módulo fiscal; } \\
8 \text { (oito) metros, para } \\
\text { imóveis rurais com } \\
\text { área superior a } 1(\mathrm{um})\end{array}$ \\
\hline
\end{tabular}

${ }^{111}$ Imagem disponibilizada pelo IBGE. Disponível em: $<$ ftp://geoftp.ibge.gov.br/imagens_aereas/ortofoto/projeto_rj_escala_25mil/pdf $>$ Acesso em 20 out. 2015. 


\begin{tabular}{|c|c|c|c|}
\hline $\begin{array}{c}\text { em áreas rurais, } \\
\text { exceto os corpos } \\
\text { d'água com até vinte } \\
\text { hectares de } \\
\text { superfície, cuja faixa } \\
\text { marginal será de } \\
\text { cinqüenta metros; }\end{array}$ & $\begin{array}{c}\text { com até 20 (vinte) } \\
\text { hectares de } \\
\text { superfície, cuja faixa } \\
\text { marginal será de 50 } \\
\text { (cinquenta) metros; }\end{array}$ & $\begin{array}{c}\text { módulo fiscal e de até } \\
2 \text { (dois) módulos } \\
\text { fiscais; }\end{array}$ \\
& & $\begin{array}{c}15 \text { (quinze) metros, } \\
\text { para imóveis rurais } \\
\text { com área superior a 2 } \\
\text { (dois) módulos } \\
\text { fiscais e de até } 4 \\
\text { (quatro) módulos } \\
\text { fiscais; }\end{array}$ \\
& & $\begin{array}{c}\text { 30 (trinta) metros, } \\
\text { para imóveis rurais } \\
\text { com área superior a 4 } \\
\text { (quatro) módulos } \\
\text { fiscais. }\end{array}$ \\
\hline
\end{tabular}

Dessa forma, assim como nas APP de cursos d'água, em lagos e lagoas as faixas de proteção também sofrerão variação de acordo com a propriedade nas quais estiverem inseridas e não de acordo com a superfície de água que protegem. Percebe-se que as APP no entorno de lagos e lagoas serão desuniformes, como se extrai da figura abaixo, na qual um mesmo lago ou lagoa é ladeado por APP de diferentes metragens, o que não se justifica cientificamente, como já mencionado.

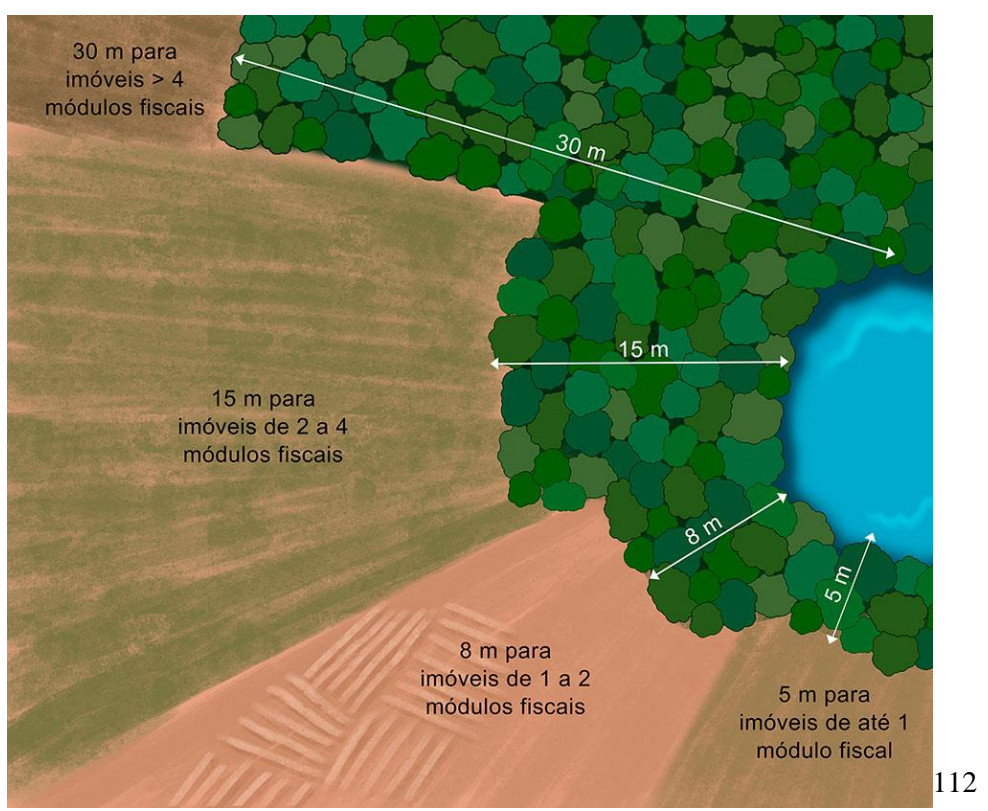

112 Centro de Inteligência em Florestas. Cartilha do Código Florestal Brasileiro. Disponível em <http://www.ciflorestas.com.br/cartilha/APP-o-que-deve-ser-recomposto-nas-areas-ruraisconsolidadas.html> Acesso em 20 out. 2015. 
Quanto às nascentes e olhos d'água, houve a exclusão de um tipo de espaço territorial especialmente protegido pela Lei federal 4.771/1965, referente às nascentes e olhos d'água intermitentes. A nova lei define tais espaços no artigo $3^{\circ}$, XVI e XVII e garante a proteção em caso de nascentes e olhos d'água perenes, num raio de 15 metros em áreas rurais consolidadas, enquanto a legislação anterior previa um raio mínimo de 50 metros.

A temeridade dessa exclusão é mencionada na Ação Direta de Inconstitucionalidade 4903, conforme destacado no trecho abaixo:

A exclusão da proteção das nascentes e dos olhos d'água intermitentes, assim como das nascentes que não dão origem a cursos d'água descaracteriza o regime de proteção de tais áreas de preservação permanente e constitui evidente retrocesso na legislação ambiental. Para ilustrar de forma concreta as consequências da legislação, segundo estudo técnico divulgado pelo Ministério Público do Estado de São Paulo, somente no Estado do Mato Grosso do Sul as áreas de preservação permanente no entorno de nascentes e olhos d'água passariam de 2.952,91 hectares, para apenas 817,70 hectares (doc. 5). ${ }^{113}$

Os topos de morro, bordas de tabuleiro, encostas com declividade acima de $45^{\circ}$ e regiões com altitude acima de 1.800 metros, cuja ocupação seja consolidada, foram alvo de um retrocesso ainda mais evidente pois nestas áreas não haverá qualquer recuperação, independentemente do tamanho do imóvel ou da data na qual houve o desmatamento (art. 63 da Lei 12.651/2012).

O retrocesso perpetrado pelo artigo 63 da nova lei é aviltante tendo em vista, por exemplo, o desastre natural, de janeiro de 2011, que ocorreu na região serrana do Estado do Rio de Janeiro, considerado o mais grave na história do país, justificado, entre outros fatores, pela ocupação irregular de topos de morro, como se extrai do trecho abaixo, proveniente mais uma vez de manifestação da comunidade científica:

Como princípio geral, todos os vales de cabeceiras de drenagem deveriam ser alvos de restrições acentuadas de uso e priorizadas como áreas de reservas de biodiversidade, de estocagem de águas e de estabilização das encostas. Os

\footnotetext{
${ }^{113}$ STF, ADI n. 4903, Rel. Ministro Luiz Fux. Petição Inicial ajuizada pelo Ministério Público Federal, em 18 jan. 2013. Pendente de julgamento. p. 27.
} 
recentes desastres impulsionados pelas chuvas extremas na região serrana do estado do Rio de Janeiro corroboram esta afirmativa na medida em que, dentre as centenas de escorregamentos mapeados pelo GEOHECO-IGEO/UFRJ no município de Friburgo (COELHO NETTO et al., 2011), mais de 50\% ocorreram na porção superior das encostas, incluindo o que seria classificado como topo de morros ou zona de cumeada. Esses estudos apontam ainda que as cicatrizes de deslizamentos estavam em grande parte associadas com áreas cobertas por vegetação de gramíneas, além de formações arbustivas e florestas degradadas. Frente ao caráter extremo das chuvas detonadoras dos escorregamentos, também as áreas com florestas mais conservadas foram atingidas, um processo natural do metabolismo da paisagem em relevos acidentados. Porém, a escala de ocorrência neste caso demonstra o efeito amplificador da degradação da vegetação natural sobre a frequência de tais eventos. Estudos anteriores no Maciço da Tijuca (COELHO NETTO et al., 2007; OLIVEIRA et al., 1996) já indicavam que, entre mais de 100 escorregamentos na vertente montanhosa de Jacarepaguá, apenas 14\% ocorreram em áreas sob floresta conservada, enquanto que $43 \%$ ocorreram em áreas sob gramíneas e $42 \%$ em áreas sob floresta degradada. Ainda na comparação com aqueles estudos, vale ressaltar que as chuvas de 1996 foram tão intensas quanto as chuvas recentes da região serrana do Rio de Janeiro, embora, no primeiro caso, tenham sido muito localizadas apenas sobre a zona de topos e cumeada, enquanto que os desastres mais recentes espraiaram sobre uma área de maior extensão. Os eventos ora mencionados apontam que, se por um lado as encostas ultrapassaram seus respectivos limiares de resistência frente à alta intensidade das chuvas detonadoras, por outro, ficou evidente que a presença e conservação da Floresta Atlântica de Encosta, nas condições de relevo montanhoso, favoreceram largamente a mitigação dos efeitos desastrosos dos eventos extremos de chuvas. Os estudos mostram, portanto, que a conservação e reabilitação funcional das florestas nestas áreas de topos de morros e zonas de cumeadas devem ser consideradas prioritárias". ${ }^{114}$ (Grifos meus).

Sobre a permissão dos desmatamentos consolidados em APP de topos de morro e pela perspectiva do desastre mencionado, abaixo apresentam-se duas imagens de um mesmo topo de morro situado na cidade de Nova Friburgo. Percebe-se, de acordo com a primeira imagem, de 25 de maio de 2010, que o morro era cortado no vértice por uma estrada e encontrava-se completamente desmatado em um dos lados. De acordo com a segunda imagem, de 19 de janeiro de 2011, percebe-se que o condomínio situado na base do morro foi inteiramente soterrado. Desse modo, é possível observar que a consolidação de áreas desmatadas em topos de morro vem legalizar futuros desastres naturais como este, o que configura fatal retrocesso socioambiental.

${ }^{114}$ SILVA, José Antonio Aleixo da et al.. O Código Florestal e a Ciência: Contribuições para o Diálogo. p. 72-73 


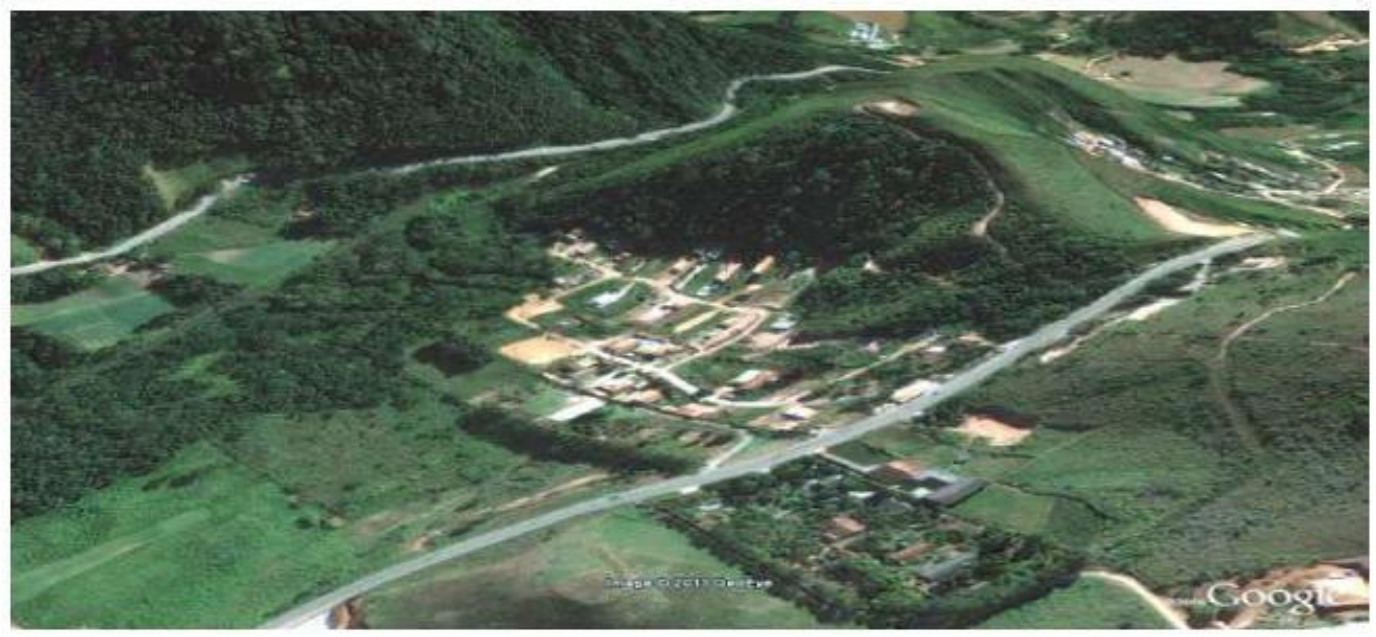

115

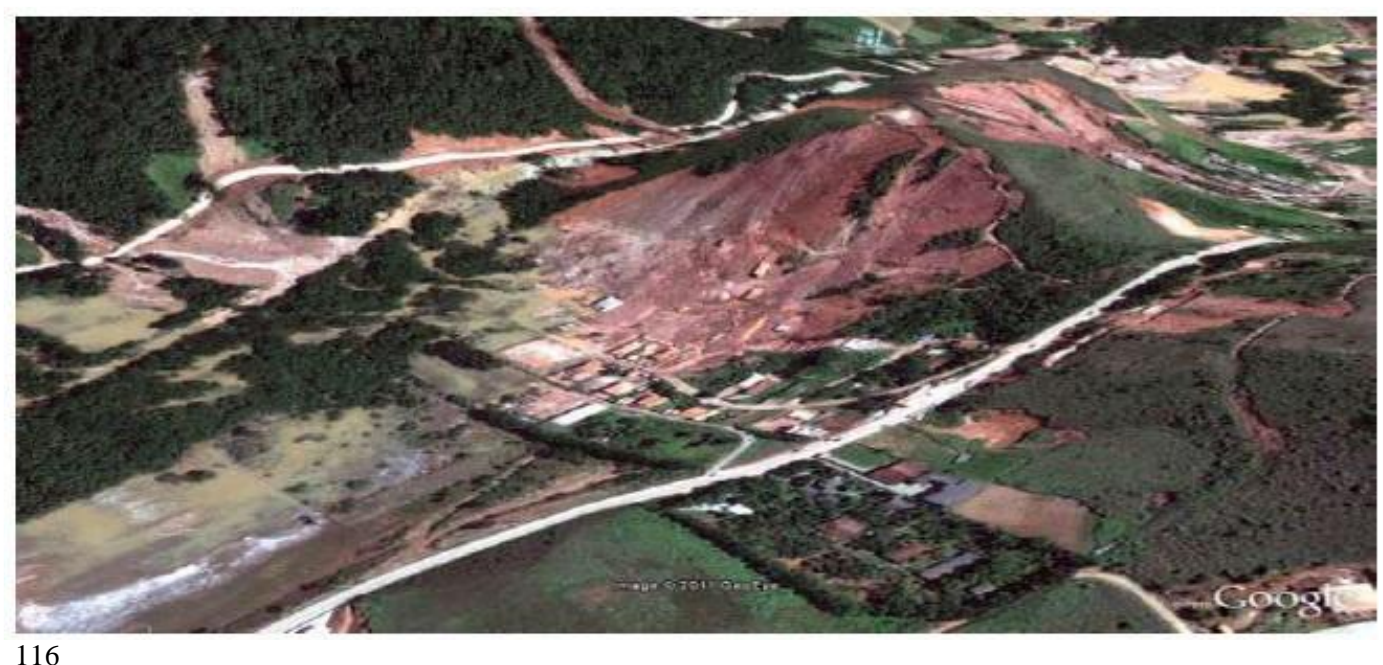

A própria definição de topo de morro da nova lei é um retrocesso, artigo $4^{\circ}$, IX, quando comparada com a Resolução Conama 303/2002 ${ }^{117}$,

115 VICTORIO, Victor Gonçalves. Impacto da aprovação do novo Código Florestal na ocupação de áreas de risco no distrito sede de Nova Friburgo, Rio de Janeiro. Rio de Janeiro, 2014.2. Monografia - PUC-Rio. p. 21.

116 VICTORIO, Victor Gonçalves. Impacto da aprovação do novo Código Florestal na ocupação de áreas de risco no distrito sede de Nova Friburgo, Rio de Janeiro. Rio de Janeiro, 2014.2. Monografia - PUC-Rio. p. 22.

${ }^{117}$ Houve controvérsias sobre a competência do Conama para definição de parâmetros de proteção das áreas de proteção permanente. Questão sanada pelo Superior Tribunal de Justiça no âmbito do Recurso Especial 994.881. Lê-se em trecho extraído da ementa do Acórdão: 2. Pelo exame da legislação que regula a matéria (Leis 6.938/81 e 4.771/65), verifica-se que possui o Conama autorização legal para editar resoluções que visem à proteção do meio ambiente e dos recurso naturais, inclusive mediante a fixação de parâmetros, definições e limites de Áreas de Preservação Permanente, não havendo o que se falar em excesso regulamentar. 3. Assim, dentro do contexto fático delineado no acórdão recorrido, e, ainda, com fundamento no que dispõe a Lei n. 6.938/81 e o artigo $2^{\circ}$, "f", da Lei n. 4.771/65, devidamente regulamentada pela Resolução Conama n. $303 / 2002$, é inafastável a conclusão a que chegou o Tribunal de origem, no sentido de que os 
artigo $3^{\circ}, \mathrm{V}$, que regulava a matéria antes da revogação do Código Florestal de 1965. Calculava-se a APP de topo de morro a partir da curva de nível correspondente a dois terços da altura mínima da elevação em relação à base, enquanto na nova lei a medição é feita da seguinte forma:

$[\mathrm{N}] \mathrm{o}$ topo de morros, montes, montanhas e serras, com altura mínima de 100 (cem) metros e inclinação média maior que $25^{\circ}$, as áreas delimitadas a partir da curva de nível correspondente a 2/3 (dois terços) da altura mínima da elevação sempre em relação à base, sendo esta definida pelo plano horizontal determinado por planície ou espelho d'água adjacente ou, nos relevos ondulados, pela cota do ponto de sela mais próximo da elevação.

O que significa que a APP será calculada a partir do ponto de sela mais próximo do topo, como se observa na figura abaixo, na qual o ponto de sela utilizado como referência é o mais alto, enquanto, de acordo com a lei anterior, deveria ser o ponto mais abaixo.

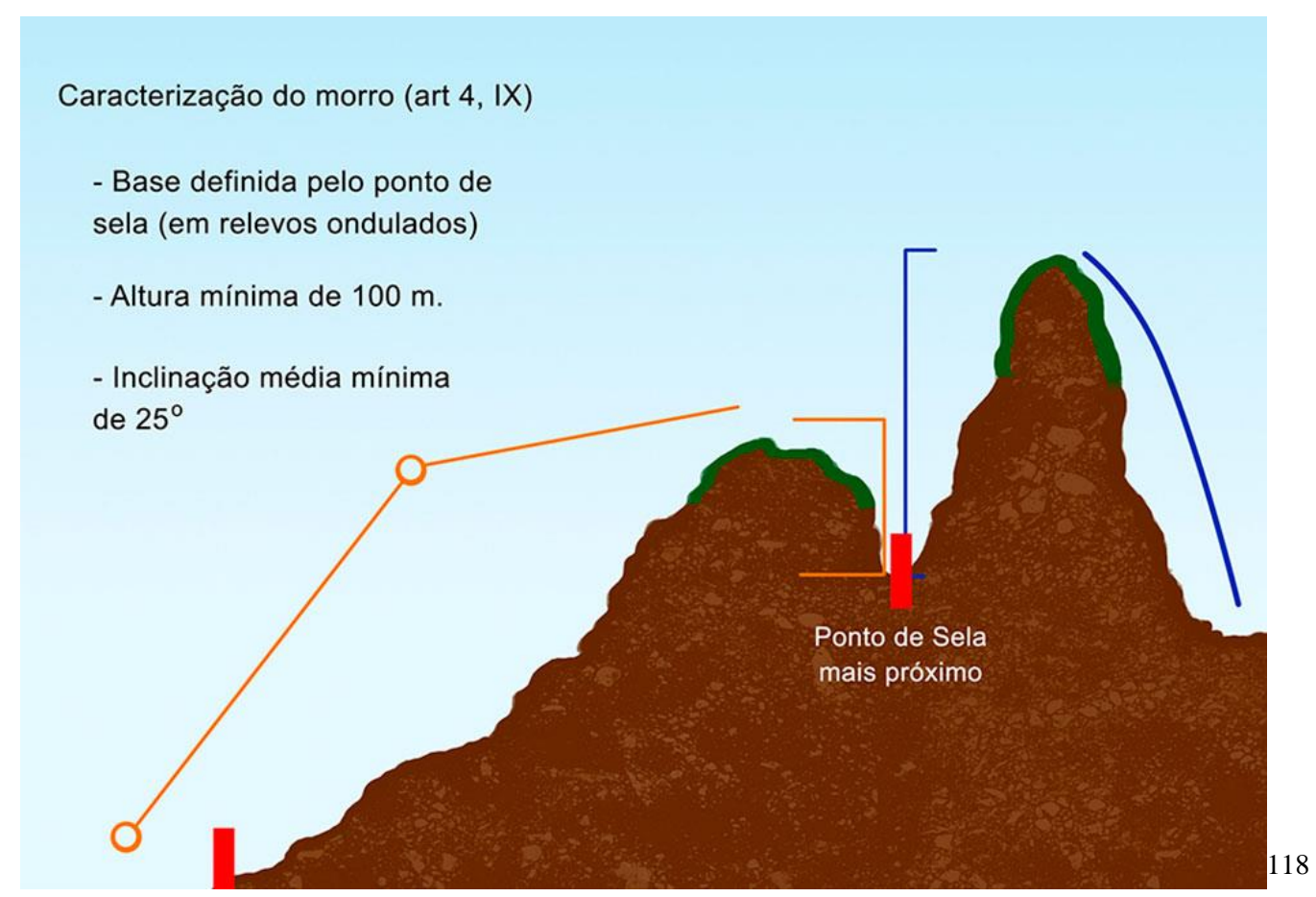

A alteração da definição das APP em topos de morro e a consequente perda da área protegida podem ser observadas na imagem abaixo, também

limites traçados pela norma regulamentadora para a construção em áreas de preservação ambiental devem ser obedecidos.” STJ, REsp n. 994.881, Rel. Ministro Benedito Gonçalves, Brasília, 16 dez. 2008.

118 Imagem extraída do seguinte documento: Centro de Inteligência em Florestas. Cartilha do Código Florestal Brasileiro. Disponível em <http://www.ciflorestas.com.br/cartilha/APPlocalizacao-e-limites_protecao-conservacao-dos-solos-manutencao-da-recarga-hidrica.html> Acesso em 20 out. 2015. 
do Município de Nova Friburgo, na qual o traçado verde corresponde à área protegida como topo de morro, de acordo com a Lei federal 4.771/1965, enquanto o traçado vermelho corresponde à área dos topos de morro em relação aos parâmetros da Lei federal 12.651/2012. Percebe-se que uma extensa área deixou de ser considerada como APP e que, portanto, houve um retrocesso quanto aos padrões de proteção já alcançados.

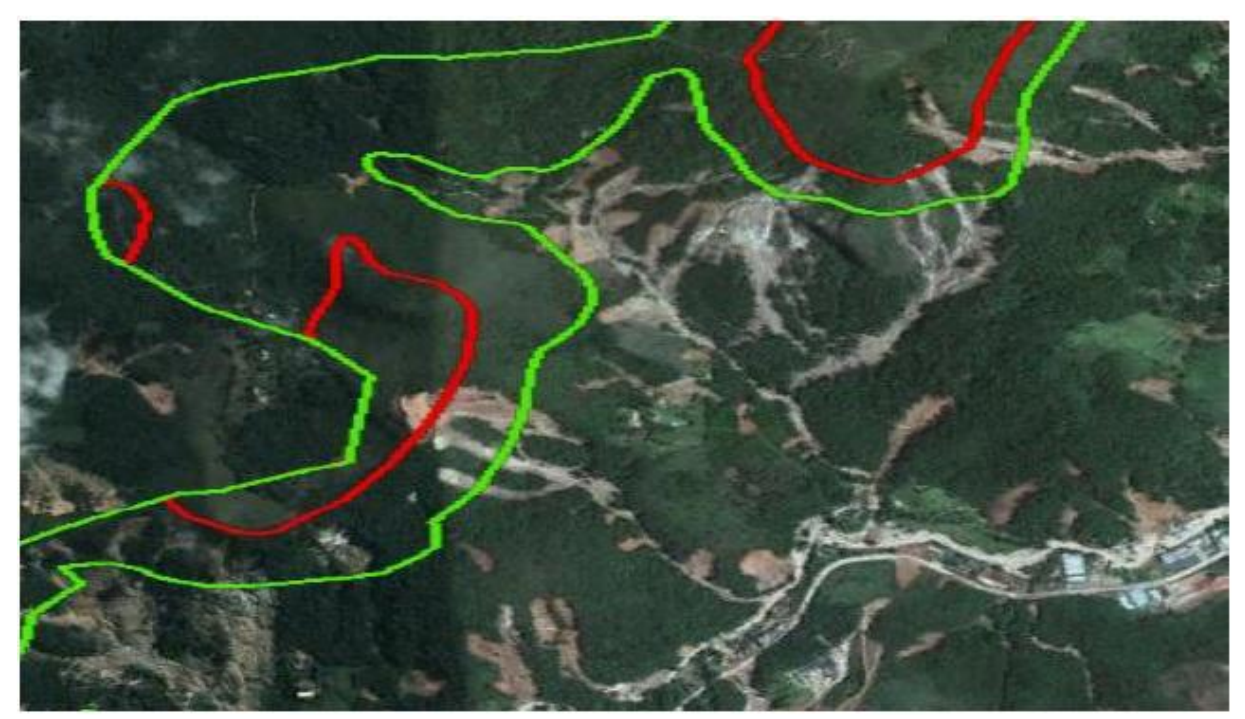

Percebe-se que mesmo as áreas em verde, protegidas pela lei anterior, sofreram diversos escorregamentos, o que demonstra a periculosidade de uma possível ocupação humana no local. A pesquisa utilizada sobre o assunto alerta, ainda, para o perigo da ocupação após a cicatrização dos deslizamentos, pela regeneração da vegetação, o que tornará ocultos os pontos de escorregamento de terra.

Outro exemplo de retrocesso constante da nova lei está no artigo $8^{\circ}$ que prevê nos casos de utilidade pública, interesse social e baixo impacto, poderá ser realizada a supressão da vegetação em área de APP. Este dispositivo não exige a indicação de uma alternativa locacional à área de preservação permanente ou, ainda, a necessidade de compensação dos

\footnotetext{
119 VICTORIO, Victor Gonçalves. Impacto da aprovação do novo Código Florestal na ocupação de áreas de risco no distrito sede de Nova Friburgo, Rio de Janeiro. Rio de Janeiro, 2014.2. 41 p. Monografia - PUC-Rio. p. 36.
} 
impactos ambientais, como ocorria na Lei de 1965. A nova Lei só prevê a necessidade de alternativa locacional quando se tratar de outras atividades não previstas no artigo $3^{\circ}$, VIII, alíneas "a" a "d", e IX, alíneas "a" a "f". A ausência de exigência de medidas mitigadoras e compensatórias quando autorizadas intervenções ou supressões em área de APP, abre a possibilidade para o entendimento de que não há exigência legal de compensação ambiental nesses casos. O que se revela perigoso, na medida em que qualquer intervenção em área especialmente protegida como é a APP, causa danos que necessitam ser compensados ${ }^{120}$.

$\mathrm{O}$ artigo $3^{\circ}$ conceitua os casos de utilidade pública, interesse social ou baixo impacto, identificando nas sucessivas alíneas dos VIII, IX e X as situações cabíveis. Nota-se que houve um aumento significativo dos casos enquadrados como tais, o que permite que a supressão ou alteração de áreas de preservação permanente sejam autorizadas em inúmeras situações. Um exemplo está presente na alínea "b" do inciso VIII, na qual se abre a possibilidade de construção de estabelecimentos esportivos em APP.

Além disso, o rol trazido pela Lei é meramente exemplificativo. Prova disso são as alíneas “e”, VIII; " $g$ ”, IX e " $k$ ”, X, todas do artigo $3^{\circ}$.

Fica a cargo do Chefe do Poder Executivo federal a definição de novas atividades similares às de utilidade pública e interesse social. Resta comprovado o aumento das possibilidades de intervenção e supressão das áreas de preservação permanente, indo de encontro com o princípio da vedação ao retrocesso e esvaziando a premissa do adjetivo permanente.

Na ADI 4903, o Ministério Público Federal menciona, ainda, que a maioria das alíneas citadas se enquadram de forma justa nos casos de permissão de supressão desde que falte a alternativa técnica e/ou locacional

\footnotetext{
${ }^{120}$ FRANCO, Ana Claudia La Plata de Mello e GIACOMOLLI, Gabriela Silveira. Comentários ao artigo $8^{\circ}$ da Lei 12.651/2012. In: MILARÉ, Édis; MACHADO, Paulo Affonso Leme (Org.). Novo Código Florestal: Comentários à Lei 12.651, de 25 de maio de 2012, à Lei 12.727, de 17 de outubro de 2012 e ao Decreto 7.830, de 17 de outubro de2012. 2a ed. São Paulo: Revista dos Tribunais, 2013. p. 180-185.
} 
- condição que, repita-se, não consta no texto do atual Código Florestal, como ocorria na Lei anterior -, a exemplo dos serviços de transporte, mas frisa que a permissão de construções com finalidade esportiva ou de tratamento de resíduos é absurda, visto que nitidamente poderiam ser instaladas em local diverso ${ }^{121}$.

Um último exemplo a ser mencionado neste trabalho sobre os retrocessos perpetrados pela nova Lei no âmbito das áreas de preservação permanente, é a extinção destes espaços nos reservatórios de água naturais ou artificiais cuja superfície seja inferior a 1 (um) hectare, prevista no artigo $4^{\circ}, \S 4^{\circ}$ e a diminuição das APP em reservatórios para abastecimento e geração de energia, de acordo com o artigo $5^{\circ}$, ambos da Lei federal 12.651/2012. Houve completo desvirtuamento do dever de proteção das funções ecológicas desempenhadas pelas APP dos exemplos mencionados, pois em um caso houve extinção de uma categoria de APP e no outro a diminuição de parâmetros já estabelecidos pela Lei, violando o núcleo duro já estabelecido pelo Direito, em nítido descompasso com o princípio da vedação ao retrocesso socioambiental.

Apresentados alguns dos pontos que se considera retrocessivos em relação às APP, passa-se à análise dos dispositivos referentes às áreas de reserva legal.

\subsubsection{Reserva legal}

$\mathrm{O}$ artigo $3^{\circ}$, III, da nova Lei florestal define o instituto da reserva legal (RL) da seguinte forma:

Reserva Legal: área localizada no interior de uma propriedade ou posse rural, delimitada nos termos do art. 12, com a função de assegurar o uso econômico de modo sustentável dos recursos naturais do imóvel rural, auxiliar a conservação e a reabilitação dos processos ecológicos e promover a conservação da

\footnotetext{
${ }^{121}$ STF, ADI n. 4903. Petição Inicial ajuizada pelo Ministério Público Federal, em 18 jan. 2013.
} Pendente de julgamento. 
biodiversidade, bem como o abrigo e a proteção de fauna silvestre e da flora nativa; ${ }^{122}$

A RL visa a garantir que todo imóvel rural tenha preservado um percentual mínimo de sua vegetação nativa, que varia de acordo com o Bioma no qual a propriedade está inserida, como estabelece o artigo 12, I e II da Lei federal 12.651/2012. Assim, na Amazônia Legal os percentuais são de $80 \%$ em áreas de florestas, 35\% em área de cerrado e 20\% em campos gerais. Nas demais regiões do país, o percentual de reserva legal deve ser de $20 \%$, independentemente do tipo de vegetação que a região abrigue. Para MACHADO, a reserva legal florestal é um "estoque vegetal para conservar a biodiversidade". ${ }^{123}$

A definição de reserva legal na nova Lei traz uma modificação expressiva em relação ao Código Florestal de 1965. Menciona como função da reserva legal o seu uso econômico, mediante manejo florestal sustentável, o que para MELO NETO significa a abertura de um perigoso precedente $^{124}$. A legislação de 1965 não incluía o termo econômico, mas tão somente falava em conservação, uso sustentável e proteção da fauna e da flora nativas.

Mais uma vez, buscando-se uma abordagem científica das funções ecológicas das áreas estudadas neste trabalho, cabe mencionar a Sociedade Brasileira para o Progresso da Ciência (SBPC) e a Academia Brasileira de Ciências quanto às reservas legais:

A Reserva Legal tem funções ambientais e características biológicas distintas das APPs em termos da composição e estrutura de sua biota. Na Amazônia, a redução das RLs diminuiria a cobertura florestal para níveis que comprometeriam a continuidade física da "floresta devido a prováveis alterações climáticas. Portanto, a redução de RLs aumentaria significativamente o risco de extinção de espécies e comprometeria a efetividade dessas áreas como ecossistemas funcionais e seus serviços ecossistêmicos e ambientais. Nos biomas com índices maiores de antropização, como o Cerrado, a Caatinga e algumas áreas altamente

\footnotetext{
${ }^{122}$ Art. $3^{\circ}$, III, Lei 12.651 , de 25 de maio de 2012.

${ }^{123}$ MACHADO, Paulo Affonso Leme. Direito Ambiental Brasileiro. p. 757.

${ }^{124}$ NETO, João Evangelista de Melo. Comentários ao artigo 3ㅇ, inciso III da Lei 12.651/2012. In: MILARÉ, Édis; MACHADO, Paulo Affonso Leme (Org.). Novo Código Florestal: Comentários à Lei 12.651, de 25 de maio de 2012, à Lei 12.727, de 17 de outubro de 2012 e ao Decreto 7.830, de 17 de outubro de2012. $2^{\mathrm{a}}$ ed. São Paulo: Revista dos Tribunais, 2013. p. 76.
} 
fragmentadas como a Mata Atlântica e partes da Amazônia, os remanescentes de vegetação nativa, mesmo que pequenos, têm importante papel na conservação da biodiversidade e na diminuição do isolamento dos poucos fragmentos da paisagem. Tais remanescentes funcionam como trampolins ecológicos no deslocamento e na dispersão das espécies pela paisagem. Essas características exigem que eventuais compensações sejam feitas na própria microbacia ou na bacia hidrográfica. As características fitoecológicas da área a ser compensada - e não o bioma como um todo, devido à alta heterogeneidade de formações vegetais dentro de cada bioma - devem ser a referência para a compensação. A restauração das áreas de RL, viável graças ao avanço do conhecimento científico e tecnológico, deve ser feita preferencialmente com espécies nativas, pois o uso de espécies exóticas compromete sua função de conservação da biodiversidade e não assegura a restauração de suas funções ecológicas e dos serviços ecossistêmicos. O uso de espécies exóticas pode ser admitido, mas na condição de pioneiras, conforme a legislação vigente. É na Reserva Legal que se constata o maior passivo ambiental do setor agropecuário brasileiro. Novas técnicas de restauração da RL usando as áreas de menor aptidão agrícola e incorporando o conceito de manejo sustentável de espécies nativas para a produção de madeiras e firas, de medicinais, de frutíferas nativas e outras permitidas pela legislação são alternativas viáveis de diversificação de produção com retorno econômico significativo. ${ }^{125}$ (Grifos meus).

Assim como demonstrado a respeito das áreas de preservação permanente, diversos dispositivos da nova Lei foram suscitados no que tange às áreas de reserva legal pelas ações diretas de inconstitucionalidade mencionadas. São eles: (i) inconstitucionalidade da redução da reserva legal em virtude da existência de terras indígenas e unidades de conservação (art. $12, \S \S 4^{\circ}$ e $5^{\circ}$ ); (ii) inconstitucionalidade da dispensa de constituição de reserva legal por empreendimentos de abastecimento público de água e tratamento de esgoto, ou por detentores de concessão, autorização para explorar energia elétrica e nas áreas adquiridas ou desapropriadas para implantação e ampliação da capacidade de ferrovias e rodovias (art. 12, § $6^{\circ}, \S 7^{\circ}$ e $\S 8^{\circ}$ ); (iii) inconstitucionalidade da permissão de instituição de servidão ambiental sobre o excedente de reserva legal fruto da diminuição de parâmetros na Amazônia Legal, de acordo com o Zoneamento Ecológico Econômico (art. 13, § $1^{\circ}$ ); (iv) inconstitucionalidade da autorização para cômputo de áreas de preservação permanente no percentual de reserva legal (art. 15); (v) inconstitucionalidade da permissão do plantio de espécies exóticas para recomposição da reserva legal (art. 66, § 3º); (vi)

\footnotetext{
${ }^{125}$ SILVA, José Antonio Aleixo da et al.. O Código Florestal e a Ciência: Contribuições para o
} Diálogo. p. 13 
inconstitucionalidade da compensação da reserva legal sem que haja identidade ecológica entre as áreas, e da compensação por arrendamento ou pela doação de área localizada no interior de unidade de conservação a órgão do poder público (art. $48, \S 2^{\circ}$, e art. $66, \S 5^{\circ}$, II, III e IV, e $\S 6^{\circ}$ ); (vii) inconstitucionalidade da consolidação das áreas desmatadas de acordo com a legislação em vigor à época do desmatamento (arts. 12 e 68, caput); (viii) inconstitucionalidade da isenção dos desmatamentos ocorridos antes de 22 de julho de 2008 (art. 17, § 8 ); e (ix) inconstitucionalidade do dever de restaurar as áreas de reserva legal (art. 67).

Assim como na análise dos dispositivos considerados retrocessivos relacionados às áreas de preservação permanente, foram escolhidos alguns para exemplificar o entendimento de que, também em áreas de reserva legal, o novo Código Florestal implicou graves retrocessos socioambientais. Como se passa a analisar.

Os artigos $7^{\circ}$, $\S 3^{\circ} ; 17$, $\S 3^{\circ}$, e 67 da Lei federal $12.651 / 2012$ consubstanciam-se em flagrantes retrocessos pois preveem a consolidação dos desmatamentos realizados até 22 de julho de 2008 e desoneram os proprietários do dever de reparar os danos causados. Isso significa que, nos imóveis de até quatro módulos fiscais, aqueles que desmataram irregularmente as áreas de reserva legal não precisarão recompor a vegetação e que o percentual remanescente em 22 de julho de 2008 será o percentual a ser preservado; o que significa que propriedades que não tinham mais sua reserva legal preservada consolidarão tal situação com a benção da nova Lei. Imóveis maiores do que quatro módulos fiscais deverão recompor, regenerar ou compensar os desmatamentos realizados até 22 de julho de 2008, mediante regras e parâmetros significativamente mais flexíveis do que aqueles vigentes no Código Florestal anterior. A inconstitucionalidade destes dispositivos é patente pois violam frontalmente 
o artigo 225, caput e parágrafos $1^{\circ}, 3^{\circ}$ e $4^{\text {o126}}$, da Constituição Federal de 1988, ao ignorar a obrigação de reparar os danos causados, de restaurar os processos ecológicos essenciais desempenhados pelos espaços territoriais especialmente protegidos, compromete os atributos que justificam sua proteção e afronta os primados da função socioambiental da propriedade e do princípio da vedação ao retrocesso.

O artigo 12 da Lei 12.651/2012 trouxe modificações relevantes à delimitação das reservas legais. Os parágrafos $4^{\circ}$ e $5^{\circ}$ permitem uma redução das áreas de reserva legal, ao misturar os conceitos de unidades de conservação, zoneamento ecológico e reserva legal. Esta não pode ser confundida com as demais e, por configurar diminuição dos padrões determinados para as reservas legais ao suprimir uma em detrimento da outra, os dispositivos constituem retrocesso ambiental ${ }^{127}$. A função representada pela reserva legal independe das demais, devendo ser combinadas.

Os parágrafos $6^{\circ}, 7^{\circ}$ e $8^{\circ}$ do mesmo artigo 12 preveem que, havendo determinadas atividades, como abastecimento público de água, geração de

\footnotetext{
126 Art. 225, parágrafos $1^{\circ}, 3^{\circ}$ e $4^{\circ}$ da Constituição Federal: " $\$ 1^{\circ}$ Para assegurar a efetividade desse direito, incumbe ao Poder Público: I - preservar e restaurar os processos ecológicos essenciais e prover o manejo ecológico das espécies e ecossistemas; II - preservar a diversidade e a integridade do patrimônio genético do País e fiscalizar as entidades dedicadas à pesquisa e manipulação de material genético; III - definir, em todas as unidades da Federação, espaços territoriais e seus componentes a serem especialmente protegidos, sendo a alteração e a supressão permitidas somente através de lei, vedada qualquer utilização que comprometa a integridade dos atributos que justifiquem sua proteção; IV - exigir, na forma da lei, para instalação de obra ou atividade potencialmente causadora de significativa degradação do meio ambiente, estudo prévio de impacto ambiental, a que se dará publicidade; V - controlar a produção, a comercialização e o emprego de técnicas, métodos e substâncias que comportem risco para a vida, a qualidade de vida e o meio ambiente; VI - promover a educação ambiental em todos os níveis de ensino e a conscientização pública para a preservação do meio ambiente; VII - proteger a fauna e a flora, vedadas, na forma da lei, as práticas que coloquem em risco sua função ecológica, provoquem a extinção de espécies ou submetam os animais a crueldade. $\S 3^{\circ}$ As condutas e atividades consideradas lesivas ao meio ambiente sujeitarão os infratores, pessoas físicas ou jurídicas, a sanções penais e administrativas, independentemente da obrigação de reparar os danos causados. $\S$ $4^{\circ}$ A Floresta Amazônica brasileira, a Mata Atlântica, a Serra do Mar, o Pantanal Mato-Grossense e a Zona Costeira são patrimônio nacional, e sua utilização far-se-á, na forma da lei, dentro de condições que assegurem a preservação do meio ambiente, inclusive quanto ao uso dos recursos naturais."

${ }^{127}$ STF, ADI n. 4901, Rel. Ministro Luiz Fux. Petição Inicial ajuizada pelo Ministério Público Federal, em 18 jan. 2013. Pendente de julgamento. p 15.
} 
energia, ampliação de rodovias, não se faz necessária constituição de reserva legal. Estando o imóvel em área rural, independente da atividade exercida na propriedade, não poderia haver a dispensa da reserva legal, tal como estabelecia a revogada Lei 4.771/1965. Configura-se grave retrocesso, na medida em que tal dispensa não prevê, como na Lei anterior, sequer a compensação dos danos causados. ${ }^{128}$

O artigo 15 do novo Código Florestal também descaracterizou a função ecológica desempenhada pela reserva legal, ao possibilitar que, em qualquer propriedade, a APP seja computada dentro do percentual de reserva legal. Isso possibilita que, mais uma vez, abra-se margem para que a reserva legal deixe de existir, tendo em vista que a APP possa ser superior ao percentual de reserva legal exigido em determinada propriedade. A função da reserva legal mais uma vez é anulada, violando-se o limite que a Constituição impõe à utilização de um espaço territorial especialmente protegido de forma que não comprometa os atributos que justificam sua proteção, de acordo com o artigo $225, \S 1^{\circ}$, III.

Para uma clara identificação do problema, cumpre diferenciar as funções ecológicas das reservas legais e das áreas de preservação permanente:

Uma das atuais propostas de alteração do Código Florestal expande as possibilidades de incorporar a APP no cômputo da RL de todas as propriedades. O maior objetivo dessa alteração é a redução do passivo ambiental, uma vez que esse mecanismo não deverá ser autorizado caso implique na supressão de novas áreas de vegetação nativa. Com essa alteração, uma propriedade (com mais de quatro módulos fiscais) que incluir 10\% de APP só precisará manter mais 10\% adicionais como RL; aquela que tiver mais de $20 \%$ de APP não terá de manter qualquer RL. Haveria assim uma substituição de RL por APP. Esse cálculo combinado não faz sentido em termos biológicos. Áreas de APP e RL possuem funções e características distintas, conservando diferentes espécies e serviços ecossistêmicos. Áreas de APP ripárias diferem das áreas entre rios mantidas como RL; analogamente, APPs em encostas íngremes não equivalem a áreas próximas em solos planos que ainda mantêm vegetação nativa, conservadas como RL. As APPs protegem áreas mais frágeis ou estratégicas, como aquelas com maior risco de erosão de solo ou que servem para recarga de aquífero, seja qual for a vegetação que as recobre, além de terem papel importante de conservação

${ }^{128}$ STF, ADI n. 4901, Rel. Ministro Luiz Fux. Petição Inicial ajuizada pelo Ministério Público Federal, em 18 jan. 2013. Pendente de julgamento. p 17. 
da biodiversidade. Por se localizarem fora das áreas frágeis que caracterizam as APPs, as RLs são um instrumento adicional que amplia o leque de ecossistemas e espécies nativas conservadas. São áreas complementares que devem coexistir nas paisagens para assegurar sua sustentabilidade biológica e ecológica em longo prazo. $^{129}$

Pode-se perceber o que dispõe o artigo 15 de acordo com as figuras abaixo. Na primeira figura uma propriedade possui $10 \%$ de APP e, assim, sua reserva legal deverá ser de apenas $10 \%$. Na segunda figura, havendo 20 $\%$ de reserva legal protegida e $10 \%$ de APP também protegida, os $10 \%$ excedentes podem ser vendidos como cota de reserva ambiental (CRA) ${ }^{130}$, outro instituto criado pela nova Lei, que, embora não seja inconstitucional, permite que os percentuais já existentes de floresta possam compensar percentuais que viriam a ser recuperados.

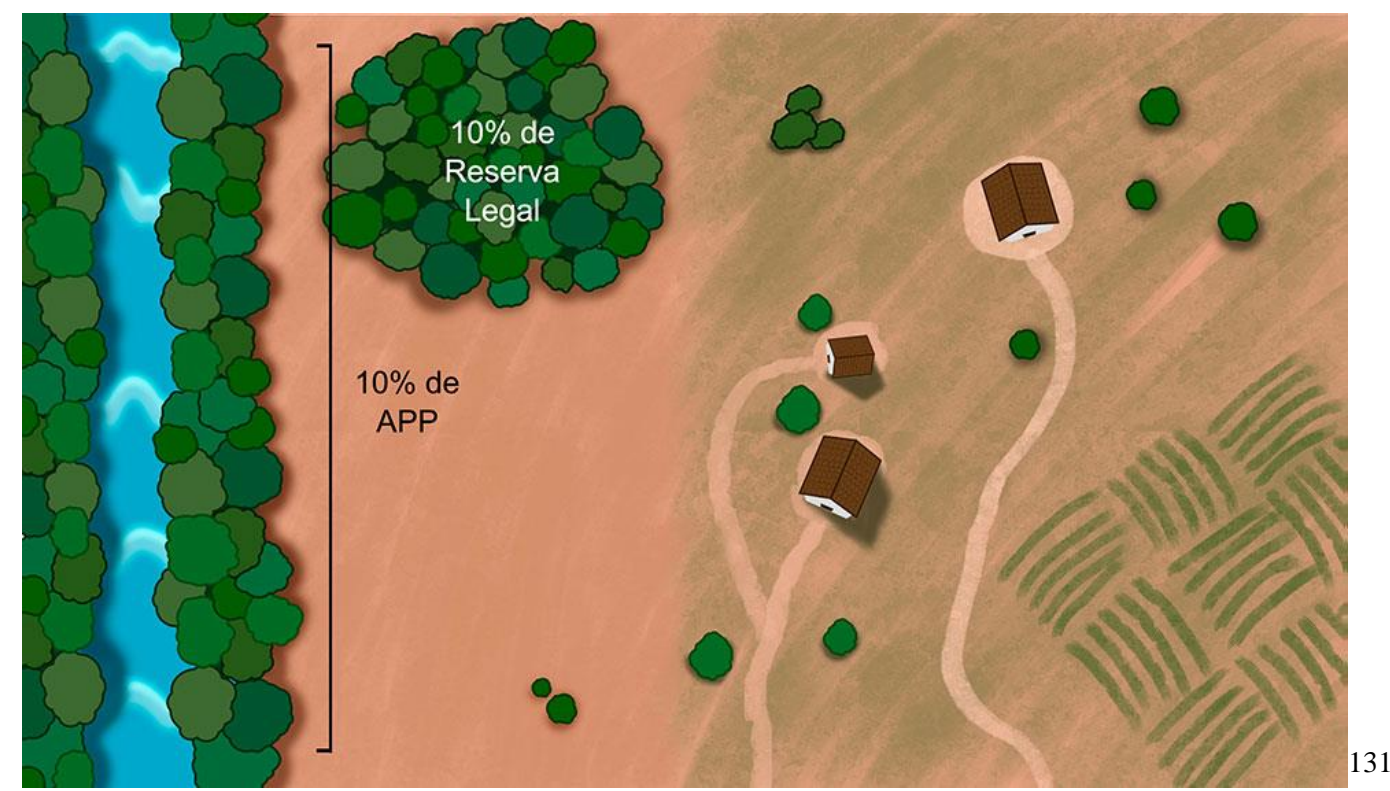

${ }^{129}$ SILVA, José Antonio Aleixo da et al.. O Código Florestal e a Ciência: Contribuições para o Diálogo. p. 48

${ }^{130}$ A Cota de Reserva Ambiental (CRA) é um título nominativo representativo de área com vegetação nativa, existente ou em processo de recuperação, previsto no art. 44 da Lei 12.651/2012. Sua função é criar um mercado de negociação de títulos de cotas de reserva legal para compensação de passivos nessas áreas. Aqueles que estiverem irregulares diante dos parâmetros de reserva legal vigentes poderão compensar o percentual faltante pela compra das CRA, ao invés de promover a recuperação da reserva legal em sua propriedade. Isso poderá ser feito desde que ambas as propriedades estejam situadas no mesmo bioma.

${ }^{131}$ Imagem extraída do seguinte documento: Centro de Inteligência em Florestas. Cartilha do Código Florestal Brasileiro. Disponível em <http://www.ciflorestas.com.br/cartilha/reservalegal qual-deve-ser-o-tamanho-da-reserva-legal.htm>l Acesso em 20 out. 2015. 


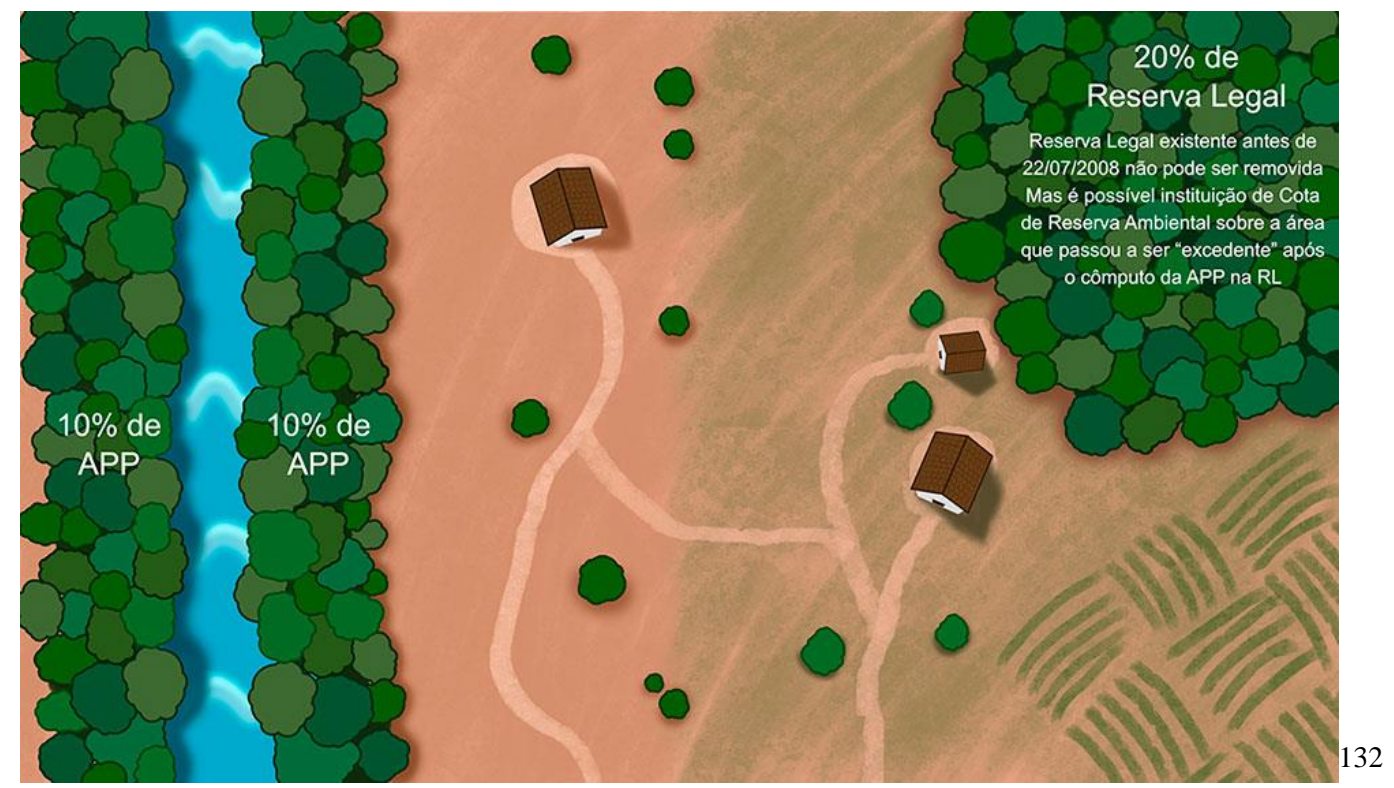

Como mencionado acima, as novas regras para recuperação da reserva legal são mais flexíveis e desconstroem o que a Lei anterior previa. Exemplificativamente, existe a possibilidade do cômputo da APP dentro do percentual previsto para a reserva legal; permite, ainda, que haja o plantio intercalado de espécies vegetais nativas e exóticas, ignorando a transitoriedade prevista pela Lei anterior sobre o plantio de exóticas, o que mais uma vez descaracteriza a função de proteção do bioma a que a reserva legal se dispõe a proteger; e, por último, o Código anterior previa a possibilidade de compensação da reserva legal, mas desde que na mesma microbacia, de acordo com o artigo 44, III, pois num país de grandes dimensões como o Brasil, permitir que a compensação ocorra no mesmo bioma significa que esta possa ocorrer até mesmo em estados diferentes, à exemplo do bioma amazônico.

O Instituto de Pesquisa Econômica Aplicada (IPEA)133 calcula que, com o novo Código Florestal, a área total de reserva legal que poderá ser perdida no Brasil é de 47 milhões de hectares, levando em

\footnotetext{
${ }^{132}$ Imagem extraída do seguinte documento: Centro de Inteligência em Florestas. Cartilha do Código Florestal Brasileiro. Disponível em <http://www.ciflorestas.com.br/cartilha/reservalegal qual-deve-ser-o-tamanho-da-reserva-legal.htm>l Acesso em 20 out. 2015.

${ }^{133}$ MOREIRA, Ana Paula. Código Florestal: Implicações do PL 1876/99 nas áreas de Reserva Legal. 
consideração a anistia dos passivos e o potencial de desmatamento das áreas isentas de recuperação. Por isso, diante do cenário de retrocessos legais e práticos demonstrado, considera-se a nova Lei uma afronta ao princípio da vedação ao retrocesso.

O Brasil é reconhecido pelo imenso patrimônio genético de suas florestas e demais vegetações nativas, além de também ser reconhecido e requisitado pelo seu potencial agrícola e agropecuário. Deste modo, é essencial conciliar o crescimento econômico dos setores produtivos mencionados com a preservação do meio ambiente, para que todo o potencial brasileiro seja aproveitado de forma sustentável.

O trabalho ${ }^{134}$ da Sociedade Brasileira para o Progresso da Ciência e da Academia Brasileira de Ciências nos mostra que, de acordo com o último censo agropecuário realizado no Brasil, em 2006, a principal utilização do solo em termos produtivos é da pecuária, ocupando 18,6\% do território nacional, o que significa um total de 158,8 milhões de hectares para pastagens. Em relação ao espaço destinado à agricultura, corresponde a 2,7 vezes o tamanho da área de lavouras. Ao mesmo tempo, de acordo com os parâmetros de proteção do Código Florestal de 1965, o passivo ambiental em áreas protegidas é de, em média, 83 milhões de hectares.

As pesquisas demonstram que o Brasil foi um dos poucos países a aumentar a área agrícola, numa margem de 45,6 \% entre os anos de 1975 e 2010. No entanto, devido aos avanços tecnológicos e científicos, o aumento da produção nesse mesmo período correspondeu a $268 \%$, o que comprova que investimentos em tecnologia fazem grande diferença no combate ao avanço sobre a vegetação nativa, principalmente se voltado para a pecuária que, como mencionado, ocupa uma parte grande do território. As áreas destinadas a esta atividade precisam investir em tecnologia para aumentar a

<http://www.ipea.gov.br/portal/images/stories/PDFs/comunicado/110608_comunicadoipea96_apr esentacao.pdf $>$ Acesso em 25 out. 2015.

${ }^{134}$ SILVA, José Antonio Aleixo da et al.. O Código Florestal e a Ciência: Contribuições para o Diálogo. p. 13 
lotação das pastagens que gira em torno de 1,1 cabeça por hectare. O aumento dessa lotação representa a liberação de terras para a agricultura, o que impediria novos desmatamentos destinados à agricultura ou à própria pecuária.

Os dados apresentados ajudam a corroborar a ideia de que o novo Código Florestal veio para resolver a questão dos passivos ambientais por meio da desoneração dos proprietários com ocupações irregulares, enquanto o foco deveria ser para a tecnologia aplicada às áreas já existentes de pastagens e agricultura, mantendo o Código Florestal de 1965 em vigor e recuperando as áreas degradadas.

Na hipótese de uma alteração legal, o que se espera é a progressiva melhoria da proteção dos espaços territoriais especialmente protegidos e das prerrogativas constitucionais a eles destinadas.

\subsection{Jurisprudência relacionada ao novo Código Florestal}

Uma análise jurisprudencial da aplicação do novo Código Florestal, entre maio de 2012 e novembro de 2015, pelos tribunais superiores, STF e STJ, registrou os resultados numéricos listados na tabela abaixo, correspondentes aos elementos de pesquisa: "12.651", "4.771" e "código florestal":

\begin{tabular}{|l|l|l|}
\hline & STF & STJ \\
\hline “12.651" & 0 & 2 \\
\hline “4.771" & 0 & 2 \\
\hline "código florestal" & 16 & 59 \\
\hline
\end{tabular}

Observou-se que, no âmbito do STF, ainda não houve casos concretos julgados sobre o tema desde a entrada em vigor do novo Código 
Florestal. Os resultados encontrados com o elemento de busca "código florestal" não tinham relação direta com a temática dos espaços territoriais especialmente protegidos ou não foram julgados por faltar algum requisito de admissibilidade perante o Tribunal.

Quanto às Ações Diretas de Inconstitucionalidade mencionados neste trabalho, ADI 4901, ADI 4902 e ADI 4903, aguarda-se julgamento.

No STJ há alguns exemplos de jurisprudência sobre a aplicação do novo Código Florestal, embora na maioria das vezes estejam relacionados a situações fáticas ocorridas na vigência do Código anterior.

A Petição no Recurso Especial 1.240.122, julgada em 02 out. 2012, trouxe um importante precedente que vem sendo mencionado nas recentes decisões sobre a Lei 12.651/2012, qual seja, sua irretroatividade.

No caso mencionado, trata-se de pretensão do recorrente à suspensão de multa por supressão irregular de vegetação em APP, com base no artigo $59, \S 5^{\circ}$ da Lei 12.651/2012. O entendimento do Ministro Relator BENJAMIN é o de que a nova Lei não pode retroagir para atingir o ato jurídico perfeito, a coisa julgada ou afetar o nível de proteção e restauração dos processos ecológicos essenciais já alcançado, como se extrai da leitura do trecho abaixo:

O esquema é bem simples: o novo Código Florestal não pode retroagir para atingir o ato jurídico perfeito, direitos ambientais adquiridos e a coisa julgada, tampouco para reduzir de tal modo e sem as necessárias compensações ambientais o patamar de proteção de ecossistemas frágeis ou espécies ameaçadas de extinção, a ponto de transgredir o limite constitucional intocável e intransponível da "incumbência" do Estado de garantir a preservação e restauração dos processos ecológicos essenciais (art. 225, § 1 $\left.{ }^{\circ}, \mathrm{I}\right)$. (...) A regra geral, pois, é a irretroatividade da lei nova (lex non habet oculos retro); a retroatividade plasma exceção, blindados, no Direito brasileiro, o ato jurídico perfeito, o direito adquirido e a coisa julgada. Mesmo fora desses três domínios de intocabilidade, a retroatividade será sempre exceção, daí requerendo-se manifestação expressa do legislador, que deve, ademais, fundar-se em extraordinárias razões de ordem pública, nunca para atender interesses patrimoniais egoísticos dos particulares em prejuízo da coletividade e das gerações futuras. Precisamente por conta dessa excepcionalidade, interpreta-se estrita ou restritivamente; na dúvida, a opção do juiz deve ser pela irretroatividade, mormente quando a ordem pública e o interesse da sociedade se acham mais bem resguardados pelo regime jurídico pretérito, em oposição ao 
interesse econômico do indivíduo privado mais bem assegurado ou ampliado pela legislação posterior. Eis a razão para a presunção relativa em favor da irretroatividade, o que conduz a não se acolherem efeitos retro-operantes tácitos, embora dispensadas fórmulas sacramentais. Indubitável que ao legislador compete modificar e revogar suas próprias leis. Ao fazê-lo, porém, seja para substituí-las por outra seja para simplesmente no seu lugar deixar o vazio, a Constituição e a Lei de Introdução às Normas do Direito Brasileiro vedam-lhe atingir direitos adquiridos, o ato jurídico perfeito e a coisa julgada constituídos sob o império do regime jurídico anterior. Em suma, a lei pode, sim, retroagir, desde que não dilapide o patrimônio material, moral ou ecológico, constitucional ou legalmente garantido, dos sujeitos, individuais ou coletivos: essa a fronteira da retroatividade. Consequentemente, mesmo que na hipótese sob apreciação judicial seja admissível, em tese, a retroação (isto é, ausente qualquer antagonismo com o ato jurídico perfeito, direito adquirido e coisa julgada), incumbe ao juiz examinar a) o inequívoco intuito de excluir (animus excludendi ), total ou parcialmente, o regime jurídico anterior quanto a fatos praticados ou sucedidos na sua vigência, e, até mais fundamental, b) o justo motivo para a exclusão - justa causa exclusionis -, que, no Direito Ambiental, deve estar totalmente conforme à garantia constitucional da manutenção dos processos ecológicos essenciais, acima referida. Por certo, todo esse debate sobre a intertemporalidade jurídico-florestal não escapará, em boa parte das demandas, de ir além do ato jurídico prefeito. A questão maior, sem dúvida, será sobre o reconhecimento de direitos ambientais adquiridos, a última fronteira da dogmática jurídica brasileira, no âmbito da credibilidade e da efetividade da transformação normativa por que passou a Teoria Geral dos sujeitos (gerações futuras) e dos bens (autonomização do direito ao meio ambiente ecologicamente equilibrado) a partir de 1981 (com a Lei da Política Nacional do Meio Ambiente) e 1985 (com a Lei da Ação Civil Pública), chegando ao ápice de 1988 (com a Constituição cidadã). (...)Cite-se, em reforço do raciocínio, que a Lei 12.651/2012 manteve, no essencial, a estrutura do Código Florestal de 1965, prevendo, entre seus vários instrumentos, as Áreas de Preservação Permanente e a Reserva Legal, bem como a natureza propter rem das obrigações ambientais de conservação e recuperação do meio ambiente. $\mathrm{O}$ ato de desmatar ilicitamente não é menos repreensível hoje do que ontem. Nem as respostas legais aos desmatadores mostram-se menos firmes agora do que antes. Ao certo, o novo Código não afastou, tampouco revolucionou os preceitos primários (essentialia ) da Lei 4.771/65, mas ateve-se ao acessório (accidentalia ) da relação jurídicoflorestal, precisamente o argumento que leva à manutenção da jurisprudência consolidada sob a égide do regramento revogado. Se não bastante, como toda legislação ambiental, do intérprete se reclama diligência hermenêutica que não negue, nem enfraqueça, apenas afirme o inafastável fundamento de toda a legislação ambiental, isto é, a já aludida preservação e restauração dos processos ecológicos essenciais (art. 225, § $\left.1^{\circ}, \mathrm{I}\right) .{ }^{.135}$

A maioria dos julgados analisados reafirma o entendimento do

Tribunal quanto à característica propter rem das áreas de APP e RL, assim como a aplicação do princípio tempus regit actum que impõe a obediência à lei vigente à época dos fatos, a exemplo dos seguintes acórdãos, Agravo Regimental no Recurso Especial 1.367.968, julgado em 17 dez. 2013; 
Recurso Especial 1.462.208, julgado em 11 nov. 2014; Agravo Regimental no Recurso Especial 1.375.265, julgado em 18 ago. 2015.

A aplicação do novo Código Florestal, tendo em vista todas as críticas e dificuldades hermenêuticas, é complexa. Pelos julgados ora analisados, percebe-se que o STJ busca manter um posicionamento voltado à proteção do meio ambiente e afinado com a Constituição. Porém, há poucos casos na jurisprudência até o momento e ainda é, portanto, impossível prever como se dará a aplicação da Lei 12.651/2012. 


\section{CONCLUSÃO}

Buscou-se demonstrar neste trabalho que a Constituição Federal de 1988 reconhece o direito fundamental ao meio ambiente ecologicamente equilibrado, tutelando-o como um bem jurídico autônomo e intrinsecamente valioso. Demonstrou-se, também, a ética da solidariedade, do bem estar coletivo e da dignidade da pessoa humana como valores e objetivos constitucionais.

A Constituição destinou um capítulo específico para o meio ambiente, consubstanciado no art. 225, mas é permeada por dispositivos voltados para a proteção do meio ambiente, instigando a participação pública, a função social da propriedade, as obrigações do Poder Público na proteção do meio ambiente, o que a faz ser a primeira Constituição verdadeiramente ecológica do país.

Mencionou-se o progresso dos direitos humanos e a perspectiva dos direitos de terceira dimensão, consolidados no âmbito da doutrina e da jurisprudência nacionais, firmando-se o entendimento de progresso dos mesmos, que alcançaram nas últimas décadas, especialmente após 1972 com a Conferência das Nações Unidas sobre meio ambiente humano, o viés ambiental, tipicamente difuso.

Abordou-se a teoria do núcleo essencial dos direitos fundamentais, demonstrando-se a existência de limites e garantias que não podem ser violados pelo legislador infraconstitucional, que são os níveis prestacionais legislativamente definidos e consolidados no ordenamento jurídico. Neste viés, buscou-se entender qual seria o núcleo essencial do direito fundamental ao meio ambiente ecologicamente equilibrado, perpassando o conceito de mínimo existencial ecológico que se busca salvaguardar, 
mínimo que acompanha as sucessivas evoluções legais e que pode ser definido como patrimônio recebido pelas gerações atuais e que deve ser transmitido à futuras gerações em melhores condições, ou seja, a proteção máxima que se tenha alcançado, relacionada aos processos ecológicos essenciais, à diversidade e integridade do patrimônio genético, à proteção da fauna e da flora e suas respectivas funções ecológicas.

Dentre os instrumentos específicos para a garantia do núcleo essencial do direito fundamental ao meio ambiente ecologicamente equilibrado, encontra-se o princípio da proibição do retrocesso socioambiental, que possui reconhecimento implícito na Constituição Federal de 1988. Princípio que busca dar eficácia normativa mínima aos direitos fundamentais, limitando a atuação do legislador infraconstitucional nos casos em que se pretenda diminuir os padrões normativos de proteção do meio ambiente. Há uma vinculação do legislador aos níveis alcançados pelo Direito, que não afeta sua discricionariedade, mas garante a segurança jurídica necessária ao nível de proteção alcançado pelos direitos sociais, econômicos, culturais e ecológicos.

O retrocesso não é um fenômeno que ocorre apenas no Brasil, mas permeia as discussões jurídicas em todo o mundo, numa verdadeira preocupação com a garantia do núcleo essencial dos direitos fundamentais. O princípio ora estudado é essencial para combater tendências retrocessivas que muitas vezes são justificadas por interesses adversos àqueles previstos constitucionalmente.

Com o objetivo de proteger biomas, ecossistemas e espécies, a Constituição determinou a criação dos espaços territoriais especialmente protegidos e a vedação de sua utilização de forma que sejam comprometidos os atributos que justificam sua proteção.

O Código Florestal de 1965 criou institutos como as áreas preservação permanente e de reserva legal, tornando-se parte do conjunto de normas que estabelecem espaços territoriais especialmente protegidos e 
que, portanto, não podem ser utilizados de forma contrária à Constituição ou de forma que seja alcançado o núcleo essencial por eles salvaguardado.

Como apresentado neste trabalho, a Lei federal $n^{\circ} 12.651 / 2012$ estabelece, de forma geral, um padrão de proteção ambiental inferior em relação ao Código Florestal revogado (Lei federal $\left.n^{\circ} 4.771 / 1965\right)$, o que igualmente é verificado em relação a pontos específicos, relacionados aos espaços territoriais especialmente protegidos, como se buscou demonstrar. Concebe, portanto, diversos retrocessos legais por meio dos exemplos apresentados neste trabalho, relacionados à diminuição dos parâmetros de proteção de diversas categorias de APP e RL e pela anistia às ocupações irregulares anteriores a 22 de julho de 2008.

A Lei federal $\mathrm{n}^{\circ} 12.651 / 2012$ padece de inconstitucionalidades nos pontos em que estabelece uma proteção menor que a legislação revogada por ofensa direta ao princípio da vedação ao retrocesso e à própria supremacia da Constituição.

Tendo em vista o panorama de (des)proteção ambiental que o novo Código Florestal apresenta, aliado ao exemplo do desastre natural na região serrana do Estado do Rio de Janeiro, é que se percebe a absoluta relevância do princípio em comento. Indispensável no combate a uma Lei que já está em vigor e que ameaça um bem difuso essencial à vida de todos, assim como indispensável no combate a toda tentativa de regresso quanto aos direitos fundamentais consolidados.

Não parece razoável, nem juridicamente consistente, o argumento conformista que aceita retrocessos como os trazidos pela Lei 12.651/2012 e, caso não sejam persistentemente combatidos, serão reiteradamente forçados em desrespeito ao direito fundamental ao meio ambiente ecologicamente equilibrado. Não se pode deixar de combater esta Lei pelo argumento de que outra mais retrocessiva poderá ser editada. É justamente para combater todas a tentativas de retrocesso e garantir a segurança jurídica tão necessária 
aos direitos humanos, que o princípio da vedação ao retrocesso deve ser defendido, implementado e divulgado.

Espera-se que a Corte constitucional brasileira faça prevalecer o núcleo essencial do direito fundamental ao meio ambiente ecologicamente equilibrado e, em última análise, a própria Constituição, em toda a sua força normativa e objetivos solidários. 


\section{REFERÊNCIAS BIBLIOGRÁFICAS}

AYALA, Patryck de Araújo. Direito fundamental ao meio ambiente, mínimo existencial ecológico e proibição de retrocesso na ordem constitucional brasileira. Revista dos Tribunais. São Paulo, n. 901, p. $29-$ 63, nov. 2010.

Direito fundamental ao ambiente e a proibição de regresso nos níveis de proteção ambiental na Constituição brasileira. In: Senado Federal. Princípio da Proibição de Retrocesso Ambiental. Brasília: Senado Federal, 2012. $\quad$ p. $207 \quad-\quad 246 . \quad$ Disponível em $<$ http://www2.senado.gov.br/bdsf/handle/id/242559 $>$ Acesso em 20 de out. 2015 .

BENJAMIN, Antonio Herman. A proteção das florestas brasileiras: Ascensão e queda do Código Florestal. Revista de Direito Ambiental. São Paulo, n. 18, p. 21-37, abr./jun. 2000.

- Constitucionalização do Ambiente e Ecologização da Constituição Brasileira. In: CANOTILHO, José Joaquim Gomes; LEITE, José Rubens Morato (Orgs.). Direito Constitucional Ambiental Brasileiro. São Paulo: Saraiva, 2007. p. $57-135$.

- Princípio da Proibição de Retrocesso Ambiental. In: Senado Federal. Princípio da Proibição de Retrocesso Ambiental. Brasília: Senado Federal, 2012. $\quad$ p. 55 - 72. Disponível em $<$ http://www2.senado.gov.br/bdsf/handle/id/242559> Acesso em 20 de out. 2015.

Hermenêutica do Código Florestal. In: ANDRIGHI, Nancy (Org.). Doutrina: edição comemorativa, 25 anos. Brasília: Superior Tribunal de 
Justiça, 2014. 616p. p. 161 - 174. Disponível em: $<$ http://www.stj.jus.br/publicacaoinstitucional/index.php/doutr/issue/archive $>$ Acesso em 18 out. 2015.

CANOTILHO, José Joaquim Gomes. Direito Constitucional e Teoria da Constituição. $7^{\mathrm{a}}$ ed. Coimbra: Almedina, 2003. 1522p.

CHEQUER, Cláudio. O princípio da proteção ao núcleo essencial do Direito Fundamental no Direito brasileiro (aplicação e delimitação). Disponível em <http://www.cartaforense.com.br/conteudo/artigos/oprincipio-da-protecao-ao-nucleo-essencial-do-direito-fundamental-nodireito-brasileiro-aplicacao-e-delimitacao/10163> Acesso em 20 out. 2015.

FENSTERSEIFER, Tiago. Direitos fundamentais e proteção do ambiente: a dimensão ecológica da dignidade humana no marco jurídico constitucional do estado socioambiental de direito. Porto Alegre: Livraria do Advogado Editora, 2008. p. 166-169.

FIORILLO, Celso Antonio Pacheco. O Denominado "Princípio da Vedação do Retrocesso, suas Atuais Referências no Supremo Tribunal Federal e Eventuais Aplicações no Direito Ambiental Constitucional Brasileiro. Revista Brasileira de Direito Ambiental. São Paulo, n. 30, p. 37 - 43, abr./jun. 2012.

FRANCO, Ana Claudia La Plata de Mello; GIACOMOLLI, Gabriela Silveira. Comentários ao artigo $8^{\circ}$ da Lei 12.651/2012. In: MILARÉ, Édis; MACHADO, Paulo Affonso Leme (Orgs.). Novo Código Florestal: Comentários à Lei 12.651, de 25 de maio de 2012, à Lei 12.727, de 17 de outubro de 2012 e ao Decreto 7.830, de 17 de outubro de2012. $2^{\text {a }}$ ed. São Paulo: Revista dos Tribunais, 2013. p. 180-185.

LAVRATTI, Paula; PRESTES, Vanêsca Buzelato. Direito e Mudanças Climáticas: Reforma do Código Florestal: limites jurídicos. São Paulo: Instituto O Direito por um Planeta Verde, 2010. 185p. Disponível em 
<http://www.planetaverde.org/arquivos/biblioteca/arquivo_2013120118134 4 7182.pdf $>$ Acesso em 20 out. 2015.

LIMA, André; BENSUSAN, Nurit; RUSS, Lian. Código Florestal: por um debate pautado em ciência. Brasília: Instituto de Pesquisa Ambiental da Amazônia (IPAM), 2014. 76p. Disponível em <http://www.ipam.org.br/biblioteca/livro/Estudo-do-Ipam-mergulha-naproducao-cientifica-existente-para-entender-importancia-das-florestas/761> Acesso em 20 out. 2015.

LOUBET, Luciano Furtado. Análise Histórica do Instituto da Reserva Legal: Interpretação do art. 68 do Novo Código Florestal (Lei 12.651/2012). Revista de Direito Ambiental. São Paulo, n. 76, p. 239 - 263, out./dez. 2014.

NETO, João Evangelista de Melo. Comentários ao artigo $3^{\circ}$, inciso III da Lei 12.651/2012. In: MILARÉ, Édis; MACHADO, Paulo Affonso Leme (Org.). Novo Código Florestal: Comentários à Lei 12.651, de 25 de maio de 2012, à Lei 12.727, de 17 de outubro de 2012 e ao Decreto 7.830, de 17 de outubro de2012. 2a ed. São Paulo: Revista dos Tribunais, 2013. p. $80-$ 84.

MACHADO, Paulo Affonso Leme. Direito Ambiental Brasileiro. $16^{\mathbf{a}}$ ed.. São Paulo: Malheiros Editores LTDA, 2008. 1126p.

MENDES, Gilmar Ferreira; BRANCO, Paulo Gustavo Gonet. Curso de Direito Constitucional. $7^{a}$ ed.. São Paulo: Saraiva, 2012. 1592p.

MILARÉ, Édis. Direito do Ambiente: A gestão ambiental em foco: doutrina, jurisprudência, glossário. $8^{\mathrm{a}}$ ed.. São Paulo: Revista dos Tribunais, 2013. 1614p.

MORAES, Maria Celina Bodin de. O Princípio da Solidariedade. In: PEIXINHO, Manoel Messias; Guerra, Isabella Franco; NASCIMENTO 
FILHO, Firly (Org.). Os Princípio das Constituição de 1988. Rio de Janeiro: Lumen Juris, 2006. p. 157 - 176.

MOREIRA, Ana Paula. Código Florestal: Implicações do PL 1876/99 nas áreas de Reserva Legal. Disponível em <http://www.ipea.gov.br/portal/images/stories/PDFs/comunicado/110608_c omunicadoipea96_apresentacao.pdf $>$ Acesso em 25 out. 2015.

PEIXOTO FILHO, Getúlio Ezequiel da. et al.. Anuário brasileiro de desastres naturais: 2011. Centro Nacional de Gerenciamento de Riscos e Desastres. Brasília: CENAD, 2012. 82p. Disponível em $<$ http://www.mi.gov.br/c/document library/get file?uuid=e3cab906-c3fb49fa-945d-649626acf790\&groupId=185960> Acesso em 07 nov. 2015.

PRIEUR, Michel. O princípio da proibição de retrocesso ambiental. In: Senado Federal. Princípio da Proibição de Retrocesso Ambiental. Brasília: Senado Federal, 2012. p. 11 - 54. Disponível em $<$ http://www2.senado.gov.br/bdsf/handle/id/242559 > Acesso em 20 de out. 2015.

PEREIRA, Jane Reis Gonçalves. Interpretação Constitucional e Direitos Fundamentais: uma contribuição ao estudo das restrições aos direitos fundamentais na perspectiva da teoria dos princípios. Rio de Janeiro: Renovar, 2006. p. 133. X

RODRIGUES, Marcelo Abelha. Áreas Consolidadas no Código Florestal (Lei 12.651/2012): Uma vergonha sem precedentes no Direito Ambiental Brasileiro. Revista de Direito Ambiental. São Paulo, n. 69, p. 345 - 356, jan./mar., 2013.

ROTHENBURG, Walter Claudius. Não retrocesso ambiental: direito fundamental e controle de constitucionalidade. In: Senado Federal. Princípio da Proibição de Retrocesso Ambiental. Brasília: Senado Federal, 2012. $\quad$ p. $247 \quad-\quad 270 . \quad$ Disponível em 
$<$ http://www2.senado.gov.br/bdsf/handle/id/242559> Acesso em 20 de out. 2015 .

SARLET, Ingo Wolfgang; FENSTERSEIFER, Tiago. Breves Considerações sobre os deveres de proteção do Estado e a garantia da proibição do retrocesso em matéria ambiental. Revista de Direito Ambiental. São Paulo, n. 58, p. 41 - 85, abr./jun. 2010.

A eficácia dos Direitos Fundamentais. Uma Teoria Geral dos Direitos Fundamentais na Perspectiva Constitucional. 11 a ed.. Porto Alegre: Livraria do Advogado, 2012. p. 413, 442.

; FENSTERSEIFER, Tiago. Notas sobre a proibição de retrocesso em matéria (sócio)ambiental. In: Senado Federal. Princípio da Proibição de Retrocesso Ambiental. Brasília: Senado Federal, 2012. p. 121 - 206. Disponível em <http://www2.senado.gov.br/bdsf/handle/id/242559> Acesso em 20 de out. 2015.

SILVA, José Antonio Aleixo da et al.. O Código Florestal e a Ciência: Contribuições para o Diálogo. São Paulo: Sociedade Brasileira para o Progresso da Ciência, SBPC; Academia Brasileira de Ciências, ABC, 2011. $124 \mathrm{p}$.

SOZZO, Gonzalo. El principio de no retroceso en el campo de la teoría jurídica: El progreso como perdurabilidad para las generaciones futuras. In: PRIEUR, Michel; SOZZO, Gonzalo (Org.). La non régression en droit de l'environnement. Bruxelles: Bruylant, 2012. p. $65-89$.

VICTORIO, Victor Gonçalves. Impacto da aprovação do novo Código Florestal na ocupação de áreas de risco no distrito sede de Nova Friburgo, Rio de Janeiro. Rio de Janeiro, 2014.2. 41 p. Monografia - PUC-Rio. 
ZAKIA, Maria José; PINTO, Luis Fernando Guedes. Guia para aplicação da nova lei florestal em imóveis rurais. Piracicaba: Imaflora, 2014. 36p. Disponível

em < http://www.imaflora.org/downloads/biblioteca/52d7c3a819c3e Guia_Apli cao_Nova_Lei_Florestal.pdf> Acesso em 20 out. 2015

Acórdãos:

STF, MS n. 22164-0, Rel. Ministro Celso de Mello, São Paulo, 30 out. 1995.

STF, MC na ADI n. 3.540-1, Rel. Ministro Celso de Mello, Brasília, 01 set. 2005 .

STF, ADI n. 1856, Rel. Ministro Celso de Mello, Brasília, 26 mai. 2011.

STF, ADI n. 4901, Rel. Ministro Luiz Fux. Petição Inicial ajuizada pelo Ministério Público Federal, em 18 jan. 2013. Pendente de julgamento.

STF, ADI n. 4902, Rel. Ministro Luiz Fux. Petição Inicial ajuizada pelo Ministério Público Federal, em 18 jan. 2013. Pendente de julgamento.

STF, ADI n. 4903, Rel. Ministro Luiz Fux. Petição Inicial ajuizada pelo Ministério Público Federal, em 18 jan. 2013. Pendente de julgamento.

STJ, REsp n. 302.906/SP, Rel. Ministro Herman Benjamin, Brasília, 26 ago. 2010 . 